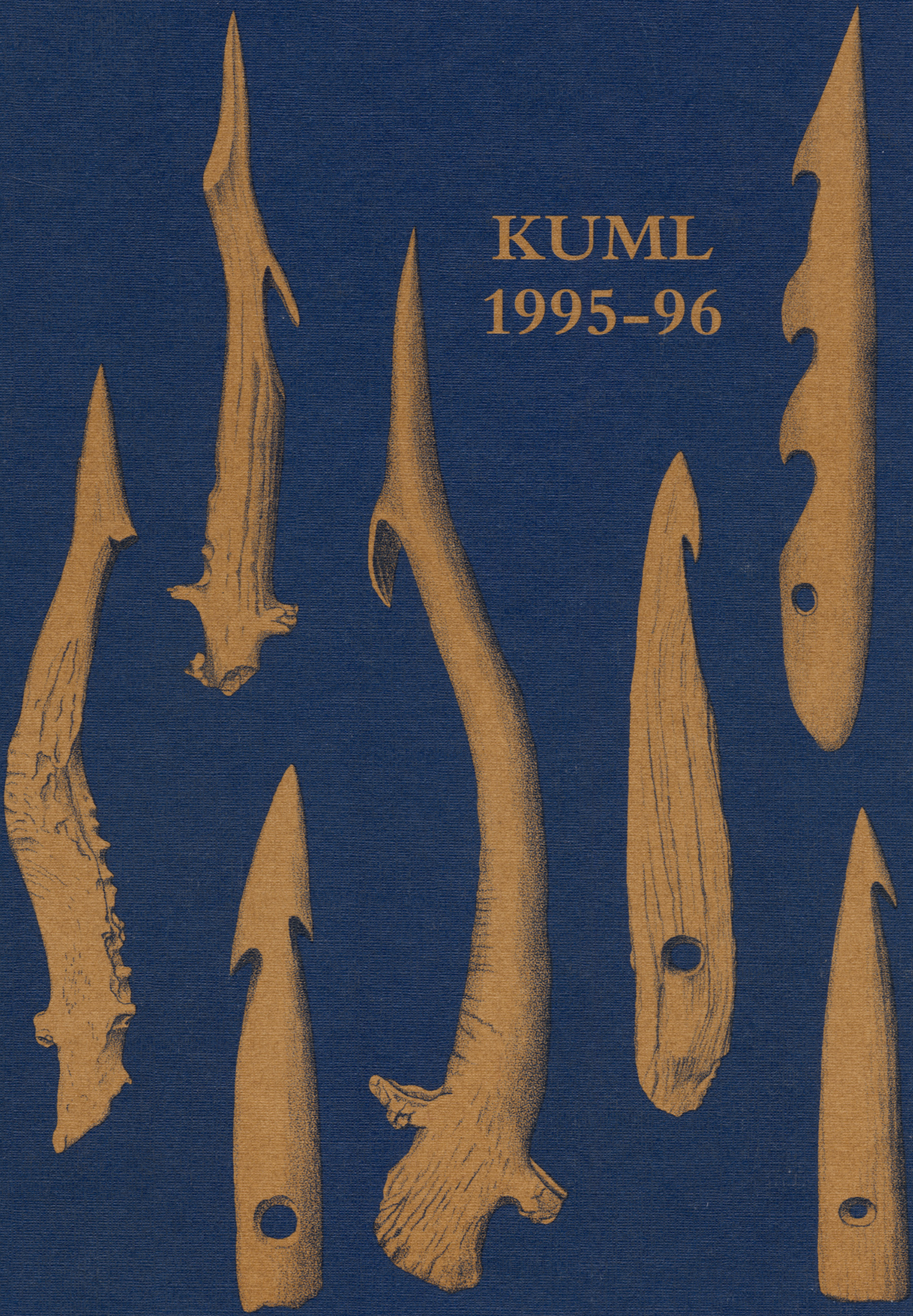


KUML 1995-96 


\section{KUML 1995-96 \\ Årbog for Jysk Arkæologisk Selskab}

With summaries in English

I kommission hos Aarhus Universitetsforlag, Århus 
Redaktion: Hans Jørgen Madsen og Jesper Laursen

Omslag: Jorgen Mührmann-Lund

Grafisk tilretteloggelse: Elsebet Morville

Tryk: Narayana Press

Skrift: Bembo 12/13

Papir: $115 \mathrm{~g}$ Arctic Silk

Copyright (C) 1997 by Jysk Arkcoologisk Selskab

ISBN 87-7288-592-0

ISSN 0454-6245 


\section{Indhold/Contents}

Palle Friis: Poul Kjærum. Worsaae-medaillen 16. maj 1996 ............................. 7

Poul Kjærum. Worsaae medal ........................................................ 10

Ole Høiris: Kampen om stenalderen. Antropologiske bud på vor oprindelse

i fortid og nutid ..................................................................................... 13

Fight over the Stone Age ................................................................. 44

Søren H. Andersen: Ertebølleharpuner og spækhuggertænder. Aspekter af marin fangst i Ertebølletid ............................................................. 45

Ertebølle harpoons and killer whale teeth. Aspects of marine hunting

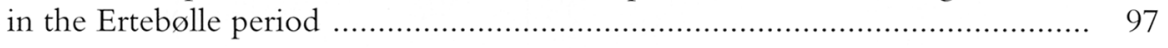

Klaus Ebbesen: Terningspil i yngre stenalder …........................................ 101

Dice and Dicing in the Stone Age ............................................... 111

Carsten Korthauer: En ældre romertidsgrav med guldmønt fra Jylland - samt nogle iagttagelser om møntomløb og -funktion i jernalderens Danmark ......... 113

An Early Roman Iron Age Grave containing a Roman Gold Coin ............. 133

Poul Mikkelsen og Lis Helles Olesen: Vendeldiget ........................................... 135

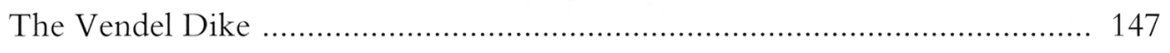

Jens Jeppesen og H.J. Madsen: Trækirke og stormandshal i Lisbjerg ...................... 149

A Wooden church and Big Man's Hall at Lisbjerg ..................................... 169

Mogens Rud: En skjult sandhed i Bayeux-tapetet? Hvad skulle Harald

Godwinson i Normandiet? ....................................................... 173

A hidden Revelation in the Bayeux tapestry? What was Harald

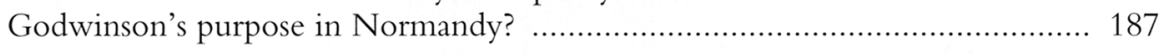

Hans Skov: Udgravningerne ved Aarhus Katedralskole i 1994-95 ....................... 189

Excavations at Aarhus Cathedral School in 1994-95 .................................. 206

Jette Linaa Larsen: Skår i tusindtal - keramik fra Torvet i Horsens

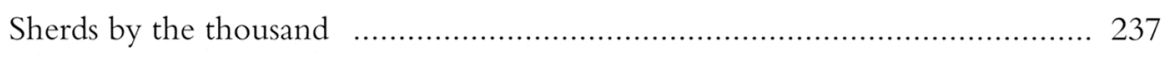

Jens Andersen: Jydepotter fra Brønderslev ................................................. 239

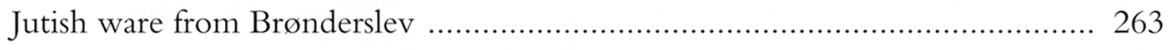

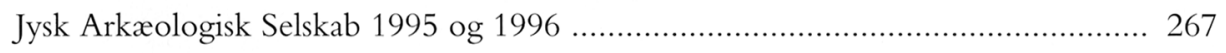




\title{
Ertebølleharpuner og spækhuggertænder Aspekter af marin fangst i Ertebølletid
}

\author{
Af Søren H. Andersen
}

Harpuner fra ældre stenalder hører til nogle af vore mere sjældne oldsagsformer, men ikke desto mindre dukker der jævnligt nye stykker op; især som enkeltfund, men heldigvis også i forbindelse med veldaterede bopladser.

Da de danske stenalderharpuner for ca. 20-25 år siden for første gang blev fremlagt samlet, var det på det tidspunkt muligt at udskille en gruppe, der kunne dateres til Ertebøllekulturen, harpuntyperne A, B og C og en restgruppe, som kun kunne henføres til yngre stenalder i almindelighed; senere er endnu en type, D blevet udskilt (S.H. Andersen 1972, 1976 og 1983).

\section{Nye harpunfund}

I de forløbne år er der fremkommet adskillige nye harpuner, men de har ikke medført væsentlige ændringer af de oprindelige resultater; tværtimod har de været med til at præcisere dateringsgrundlaget for flere af Ertebølleharpunerne, og samtidig har de nye fund nok engang været med til at understrege denne oldsagstypes mange særformer. Endvidere kommer nogle af de nye stykker fra områder, hvor der allerede ved den første fremlægning var fundet flere harpuner (f.eks. i Horsens Fjord); disse fundkoncentrationer ser altså ud til at være reelle og afspejler derfor områder, hvor den marine fangst har været særlig intensiv i Ertebølletid.

Blandt de nye fund er den velbevarede harpun fig. 1, som er lavet af skorpen af en kronhjortetak. Harpunen er enradet, og omridset er spidsovalt med tungeformet basis og kort, trekantet spids. Tværsnittet er halvcirkulært, mens den er lige i profil. Hjortetakkens overflade danner harpunens ene side, mens den anden viser gevirets porøse indre. Cirka $3,3 \mathrm{~cm}$ fra spidsen findes en enkelt modhage, som er trekantet - lidt krogformet, og 4,8 cm fra basis er der boret et dobbeltkonisk linehul med en diameter på $0,8 \mathrm{~cm}$. Længden er 19,8 cm, største bredde er $3 \mathrm{~cm}$ og tykkelsen er $1 \mathrm{~cm}$. 


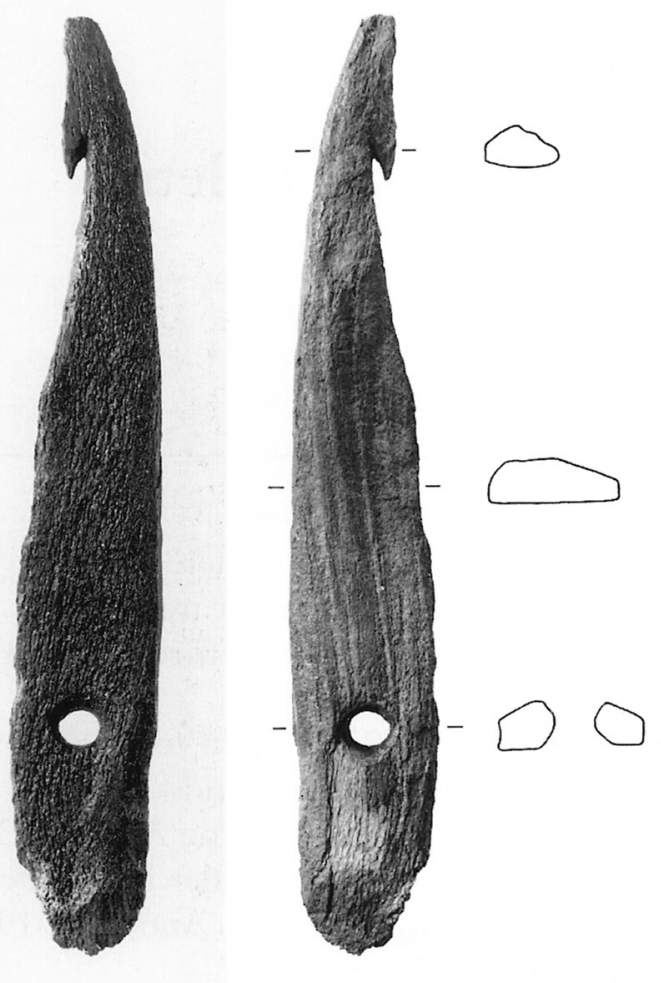

Fig. 1. Enradet Ertebølleharpun af kronhjortetak; fra undersøisk køkkenmødding ud for sydvestspidsen af Alrø, Horsens Fjord. Foto: P. Dehlholm. 1:2.

Single-edged Ertebølle harpoon of red-deer antler; from a submarine kitchen midden off the southwest corner of Alrø, Horsens Fjord.

Harpunen er opsamlet fra havbunden ud for den sydvestlige spids af Alrø (Egehoved) (1). Her ligger en stor undersøisk Ertebøllekøkkenmødding på kote $0-\div 1 \mathrm{~m}$, og harpunen er fundet på ca. kote $\div 0,75 \mathrm{~cm}$. På dette sted er der i årenes løb opsamlet et rigt og kulturelt set "rent" oldsagsmateriale fra Ertebøllekultur - dog især fra den yngre fase - med bl.a. T-formede hjortetaksøkser og keramik, der idag er på Forhistorisk Museum. Der er også fundet en del hvalknogler på lokaliteten.

Harpunen svarer formmæssigt til de tidligere publicerede Ertebølleharpuner af type A, hvilket gør det rimeligt at datere den til yngre Ertebøllekultur (S.H. Andersen 1972, s. 75, fig. 1-2 og s. 88-89, fig. 17-18), denne datering støttes også af fundforholdene.

En anden nyfunden harpun ses på fig. 2. Den er fremstillet af det yderste af en kronhjortetak, hvis spids - uden videre forarbejdning - danner harpunens od. Fire centimeter under spidsen er der ved et kraftigt indsnit dannet en modhage, som idag er delvis væk som følge af "tæring". På grund af sprossens tiltagende tykkelse mod basis er der bortskåret en del af gevirets overflade og kant for at gøre den fladere og smallere nedefter; derfor er harpunens tværsnit rundt ved spidsen og halvcirkulært mod basis. Takkens oprindelige overflade er glatskrabet, men ses kun på 

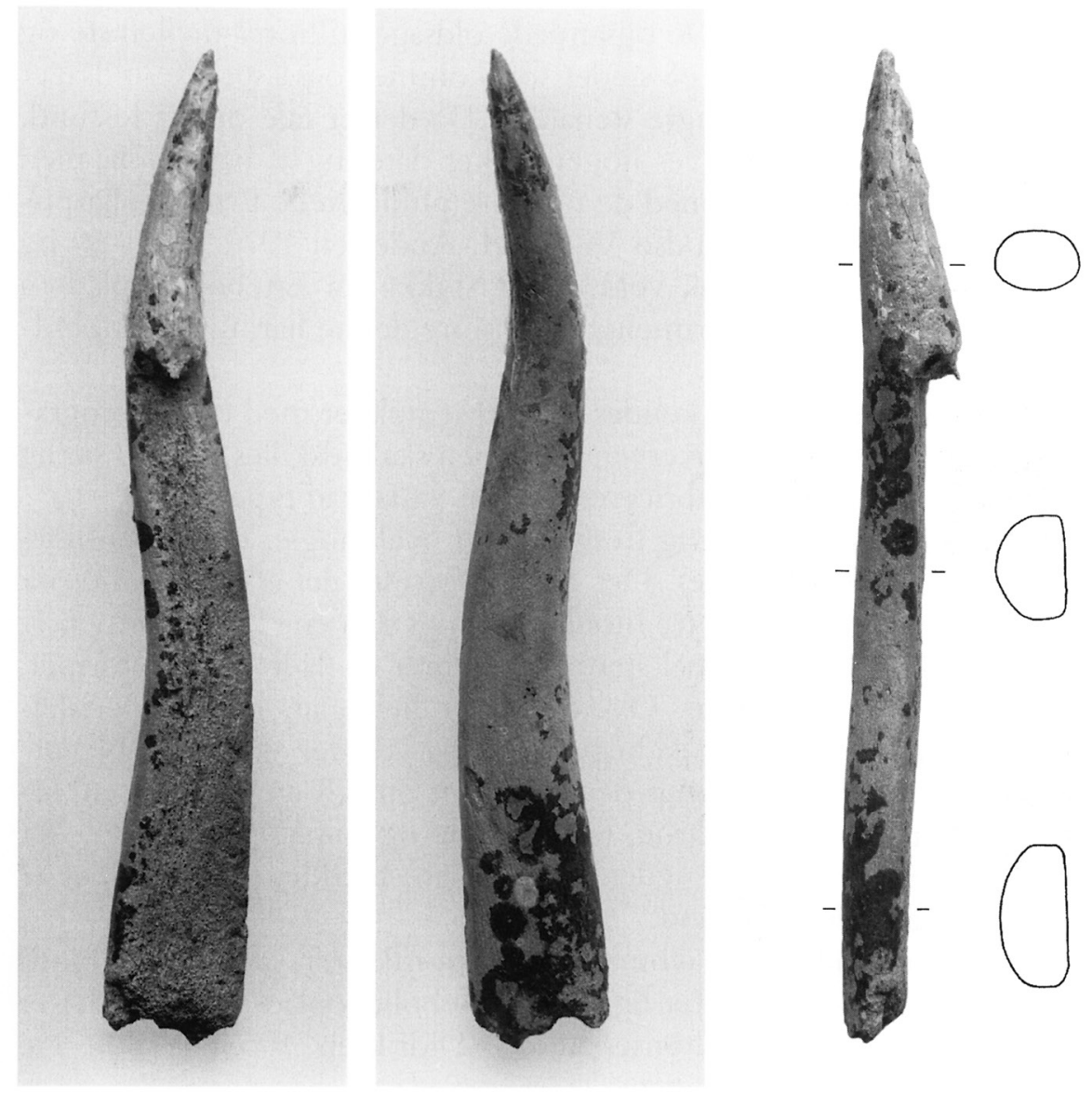

Fig. 2. Harpun fremstillet af spidsen af en kronhjortetak; fra undersøisk køkkenmødding lige vest for Alrø-dæmningen, Horsens Fjord. Foto: P. Dehlholm. 1:2.

Harpoon made from the tip of a red-deer antler; from a submarine kitchen midden just west of the Alrø dike, Horsens Fjord.

harpunens ene side (fra modhagen og til basis, mens den anden side udgøres af takkens porøse, indre væv).

Også ved spidsen er der bortskrabet noget af takkens overflade - antagelig for at gøre harpunen mere lige og symmetrisk om længdeaksen. I profil er den helt ret.Ved basis er den brækket tværs igennem hullet til snøren, hvis diameter er $0,7 \mathrm{~cm}$. Længden er $22 \mathrm{~cm}$, den største bredde er ca. $3 \mathrm{~cm}$ ved basis, og tykkelsen er 1,4 cm (ved basis).

Stykket er opsamlet på havbunden lige vest for Alrødæmningen i Horsens Fjord, ca. $50 \mathrm{~m}$ fra den nuværende kyst (2). På dette sted findes en udvasket og omlejret Ertebøllekøkkenmødding med muslingeskaller, flint, knogler, hjortetak og træ på kote ca. $\div 0,5-\div 1,0 \mathrm{~m}$. Fundområdet er aflangt og måler ca. $150-200$ x 5-10 m; stikprøvegravninger har vist, at 
laget er ca. 15-25 cm tykt. De opsamlede oldsager tilhører mellemste og yngre Ertebøllekultur, men på stedet forekommer også spredte oldsager fra forskellige perioder af yngre stenalder. Da der er tale om et løsfund, kan der ikke umiddelbart gives nogen sikker datering af harpunen, men da den både har stor lighed med de tidligere publicerede Ertebølleharpuner fra Randersegnen og Gudsø Vig (S.H. Andersen 1972, s. 88-89 og fig. 17-18) og det nyfundne, veldaterede stykke fra Ertebøllebopladsen Agernæs (se side 55), er det rimeligt at henføre denne harpun til Ertebøllekulturen.

Da denne harpunform nu kendes i fire eksemplarer med en vis geografisk spredning, bør det nok overvejes, om den skal udskilles som en særlig Ertebølletype, eller fortsat rubriceres som en variant af type A.

Harpunen fig. 3 er antagelig fremstillet af hvalknogle, men kronhjortetak kan ikke helt udelukkes. Det er den forreste del af en symmetrisk og lige harpun, som har haft tre modhager langs den ene kant. Formen er spidsoval med en lang og smal spids; tværsnittet er fladt - ellipseformet, og i profil er harpunen lige. Overfladen er helt glat, og råmaterialets porøse struktur ses sporadisk på begge sider og ved den ene kant. Nedefter er harpunen brækket. Langs den ene kant og 5,5 cm fra spidsen, ses sporene efter tre dybt indskårne, tætsiddende og spinkle modhager, der er brækket af i oldtiden. Længden er 13,9 cm, bredden ved bruddet er $1,9 \mathrm{~cm}$, og tykkelsen er $0,4 \mathrm{~cm}$.

Harpunen er fundet på havbunden nær nordkysten af Horsens Fjord ud for Uldrup Bakker (2). Her ligger en Ertebølleboplads, hvorfra der er opgravet store mængder "hønseskaller" (Didriksen 1953, s. 20). De
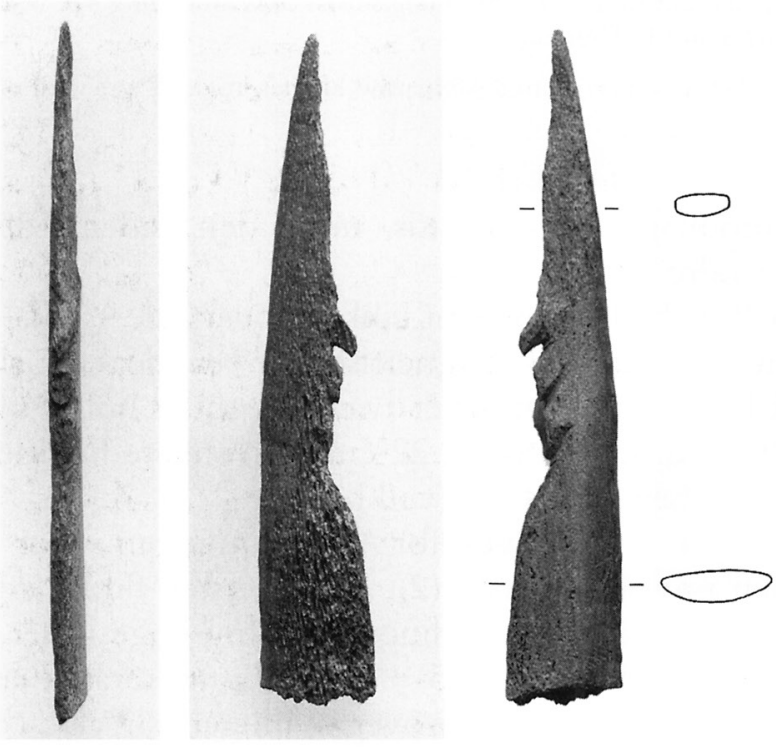

Fig. 3. Harpunspids af hvalknogle. Fra undersøisk Ertebølleboplads ved nordkysten af Horsens Fjord. Foto: P. Dehlholm. 1:2. Harpoon point of whale bone; from a submarine Ertebølle settlement near the north coast of Horsens Fjord. 

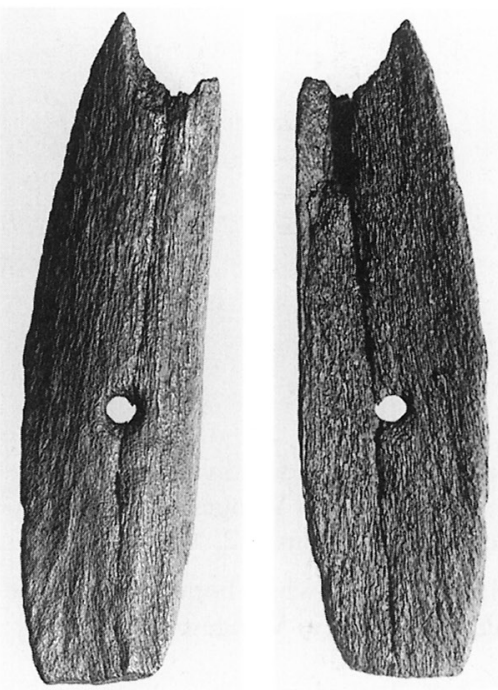

Fig. 4.Ertebølleharpun af kronhjortetak fra undersøisk boplads ved sydvestkysten af Hjarnø, Horsens Fjord. Foto: P. Dehlholm. 1:2.

Fig. 4. Ertebølle harpoon of red-deer antler from a submarine settlement near the southwest coast of Hjarnø, Horsens Fjord.

opsamlede oldsager viser, at køkkenmøddingen skal dateres til mellemste og yngre Ertebøllekultur, men fundforholdene giver selvfølgelig ikke noget afgørende bevis for samtidighed mellem harpun og boplads, selvom det er sandsynligt.

Beslægtede harpuner kendes f.eks. fra Svinninge Vejle, Gudsø Vig og Kolding Fjord, hvilket er med til at understrege dens tilhørsforhold til Ertebøllekulturen (S.H. Andersen 1972, s. 82, fig. 6; s. 92, fig. 21 og s. 97, fig. 28).

På Glud Museum opbevares en ca. 13,7 cm lang, 2,7 cm bred og 1,5 $\mathrm{cm}$ tyk spids af kronhjortetak. Stykket er symmetrisk om midtaksen og slutter i en lang, regelmæssig spids, mens basis er lige med lidt afrundede hjørner; her er der i stykkets længdeakse et lille hul, ca. 1,4 cm fra basis antagelig et hul, hvis diameter er ca. $0,8 \mathrm{~cm}$. Selvom redskabet ikke har modhage, slutter det sig nært til Ertebølleharpunerne af type A. Fra Gudsø Vig kendes et andet stykke uden modhage ( S.H. Andersen 1972, s. 90-91, fig. 20). Antagelig er det enten et forarbejde, hvor modhagen endnu ikke er udskåret, eller også er der tale om en variant af type A. Stykket er opsamlet på en undersøisk Ertebølleboplads i Horsens Fjord (3).

Fra en anden undersøisk Ertebølleboplads ud for syd-sydvestkysten af Hjarnø (også Horsens Fjord) - er der ved usystematisk udgravning fundet en hjortetaksharpun med afbrudt spids (fig. 4) (4). Harpunen er nu 13,5 $\mathrm{cm}$ lang, men har oprindelig været ca. $16 \mathrm{~cm}$; bredden er $3,6 \mathrm{~cm}$ og tykkelsen er $0,5 \mathrm{~cm}$. Den er svagt buet i længderetningen og smalner en anelse til mod basis, der er lige med lidt rundede hjørner. I midtaksen og ca. $5,5 \mathrm{~cm}$. fra basis ses et lille fanglinehul med en diameter på ca. 0,6 cm. Harpunens størrelse og form viser, at den kun har haft een modhage. Der er tale om en Ertebølleharpun af type A.

Oldsagerne fra denne boplads tilhører mellemste og yngre Ertebøllekultur, og denne datering må også gælde for harpunen.

Den enradede harpun, fig. 5, er opsamlet på markoverfladen af en kystboplads ved østsiden af Vængesø, Helgenæs (5). Det er den forreste 

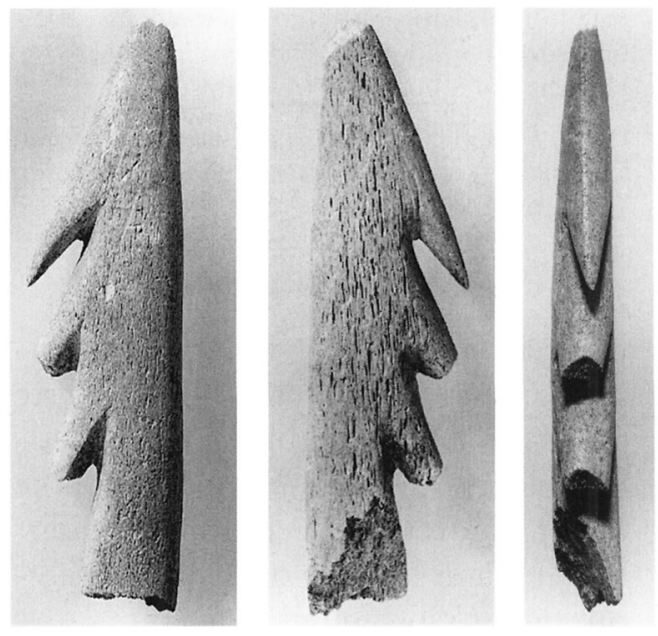

Fig. 5. Harpunspids af hvalknogle fra stenalderboplads i Vængesø, Helgenæs. Foto: P. Dehlholm. 1:2.

Harpoon tip of whale bone from a Stone Age settlement in Vængesø, Helgenæs.

del af en symmetrisk og lige harpun, der har tre modhager langs den ene kant; basis er brækket af. Modhagen nærmest spidsen er hel, mens de to næste er lidt skadede. Overfladen er helt glatskrabet, og harpunen er så kraftigt forarbejdet, at råmaterialets oprindelige overflade er helt fjernet. Tværsnittet er ovalt, og i profil er harpunen lige. Længden er 12,3 cm, bredden ved bruddet er $2 \mathrm{~cm}$, og tykkelsen er 1,3 cm, hvilket er væsentlig mere end ved de øvrige harpuner. Råmaterialet er i dette tilfælde hvalknogle.

Harpunen er fundet på en kystboplads med kulturlag fra yngre Ertebøllekultur, bl. a. med to jordfæstegrave, der er C-14 daterede til 4410 og 4440 f. Kr. (kal) (K-3920 og 3921); (S.H.Andersen m.fl. 1986, s. 4041). På stedet er der også fund fra ophold i yngre stenalder, men langt størsteparten af oldsagerne stammer fra yngre Ertebøllekultur. Som følge af fundomstændighederne kan harpunens tidsmæssige og kulturelle tilhørsforhold ikke bestemmes med sikkerhed, men må antages at ligge inden for Ertebøllekulturen. Formmæssigt må Vængesøharpunen klassificeres som en variant af Ertebølleharpunerne af type A.

Blandt de nyfundne harpuner er også stykket, fig. 6. Det er en enradet harpun fremstillet af ydersiden af et spinkelt kronhjortegevir (ungt dyr). Den er velbevaret, men overfladen er blank og tydeligt "slidt" (vandrullet). Både spidsen og basis er glatskrabet, mens resten af overfladen har gevirets oprindelige, "nubrede" yderside. Ved basis er tværsnittet halvcirkulært, mens det ved spidsen er ovalt. Harpunen er symmetrisk om længdeaksen, og har et linehul med en diameter på ca. $0,8 \mathrm{~cm}$ i længdeaksen, $5 \mathrm{~cm}$ fra basis; set i profil er harpunen lige. Spidsen er smal-trekantet, mens basis er lige overskåret med lidt rundede hjørner. I basis er der en revne, men det kan ikke afgøres, om den er oprindelig eller er et resultat af senere skade. Langs den ene kant ses fem modhager af trekan- 
Fig. 6. Lidt vandrullet, men velbevaret harpun af krondyrtak fra Klintholm, Møn. Foto: P. Dehlholm. 1:2.

Slightly water-worn, but well-preserved harpoon of red-deer antler from Klitholm, Møn.
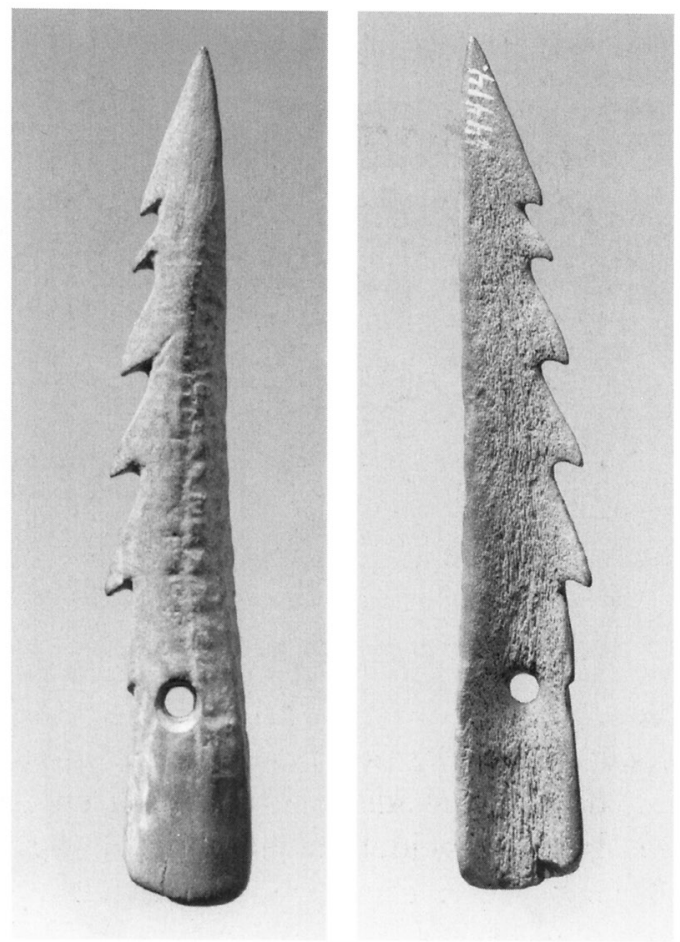

tet form, og der er spor efter endnu een, som enten er bortskåret eller afbrækket, hvorefter brudfladen er glatskrabet. Modhagerne bliver gradvis større og større fra spidsen og nedefter mod basis. Længden er 17,2 $\mathrm{cm}$, bredden er 2,6 cm ved basis, og tykkelsen er $0,5 \mathrm{~cm}$.

Harpunen er et enkeltfund, fundet på tørlagt havbund ved Klintholm Havn på Østmøn (6). Harpunen må i lighed med de øvrige, enkeltfundne og hele stykker tolkes som tabt under havjagt.

Den har ikke nogen direkte paralleller i det danske fundstof, men er mest beslægtet med Tudeå-harpunen fra ældre Ertebøllekultur (S.H. Andersen 1976) og en harpun fra grav IV på Skateholm II-gravpladsen fra ældre Ertebøllekultur (se s. 58). Indtil videre kan en sådan datering med forsigtighed også gælde for Klintholm-harpunen.

Harpunen, fig. 7, er et nyt enkeltfund fra Ulkestrup Lyng i den vestsjællandske Åmose (7). Råmaterialet er kronhjortetak. Den er velbevaret, men spidsen er afbrudt, og ved basis er der spræengt et mindre stykke af kanten. Overfladen er glatskrabet langs kanterne og på det nederste stykke af basis samt ved modhagerne. Ved den ene kant er der $-6 \mathrm{~cm}$ fra spidsen - en kort, trekantet og spinkel modhage, men ved brudstedet nær spidsen ses sporet efter endnu en modhage; harpunen har altså oprindelig haft to modhager. I midteraksen ses et linehul med en diameter på $1,2 \mathrm{~cm}$; hullet er indboret ca. $4,5 \mathrm{~cm}$ fra basis, der er regelmæssig tunge- 

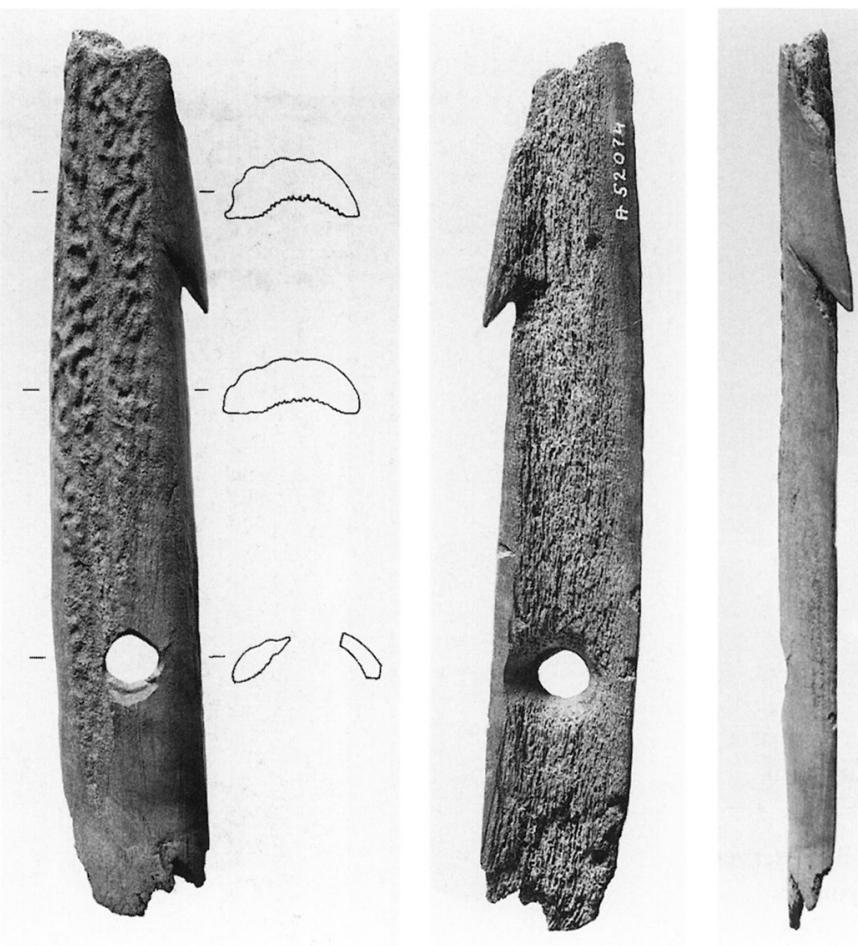

Fig. 7. Harpun af kronhjortetak fra Åmosen, Vestsjælland. Foto: P. Dehlholm. 1:2.

Harpoon of reddeer antler from Åmosen, west Zealand.

formet. Åmoseharpunen er nært beslægtet med den tidligere publicerede harpun fra Svinninge Vejle (S.H. Andersen 1972, s. 82, fig. 6).

Formmæssigt har denne harpun mange lighedspunkter med Ertebølleharpunerne af type $\mathrm{A}$ og må derfor henføres til denne gruppe (og kultur). Den nuværende længde er ca. $18 \mathrm{~cm}$, største bredde ca. 2,9 cm og tykkelsen er ca. $1 \mathrm{~cm}$.

Harpunen er et vigtigt enkeltfund, fordi den er fundet ved en tidligere indsø (i dag mose).

Der er ikke fundet andre Ertebølle harpuner af denne type i Åmosen, men i forvejen kendes der en kraftig, toradet harpun fremstillet af en hjortetaksøkse (enkeltfund) samt et brudstykke af en rådyrtakharpun fra bopladsen Tingbjerggård Syd i dette mosedrag (S.H. Andersen 1972, s. 95 og fig. 25) (8). Samtidig er harpunen interessant derved, at den er med til at understrege kontakten mellem Ertebøllebefolkningen i Åmosen og ude ved kysten. Man kan antage, at harpunen f.eks. er fremstillet ude på en kystboplads og derfra er bragt ind til Åmosen, hvor den er brugt og kasseret.

Harpunen, fig. 8, er et løsfund fremkommet ved Højerup Kirke på Stevns (9). Råmaterialet er antagelig et stykke kronhjortetak, hvis yderside tilsyneladende har været glatskrabet; muligheden for hvalknogle kan 
Fig. 8. Vandrullet harpun af kronhjortetak fra Højerup, Stevns. Foto: P. Dehlholm. $1: 2$.

Water-worn harpoon of red-deer antler from Højerup, Stevns.
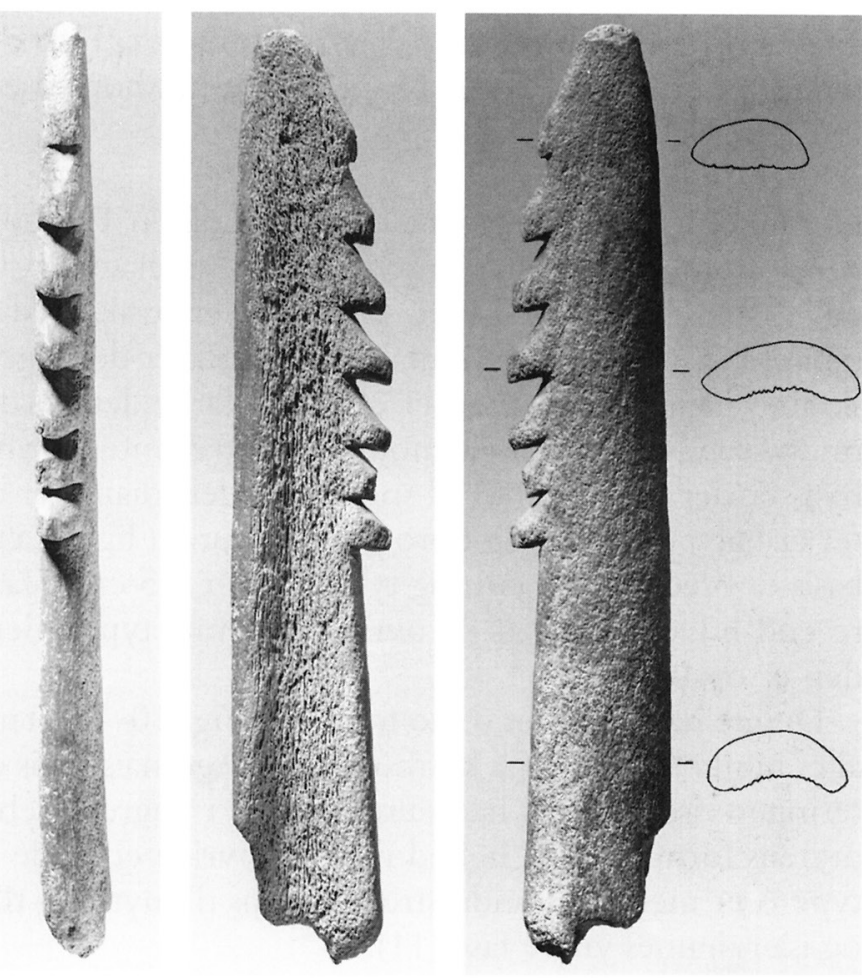

dog ikke helt udelukkes. Harpunen er noget afstødt på kanterne, og det yderste af spidsen mangler. Basis er brækket i stenalderen, og i brudfladen ses spor af linehullet. Harpunen er enradet og langs kanten ses en serie på syv små, korte, kraftige og tæetsiddende modhager, af hvilke den første begynder ca. 1,7 cm under spidsen, som er kort, bred og trekantet. Tværsnittet er halvcirkelformet, og i profil er harpunen lige. Den er nu $18,19 \mathrm{~cm}$ lang, $3,1 \mathrm{~cm}$ bred og ca. 1,2 cm tyk.

Harpunen fra Stevns knytter sig formmæssigt til gruppen af Ertebølleharpuner, men adskiller sig fra de tidligere publicerede ved dens mange, korte og tætsiddende modhager. Nærmeste paralleller er harpunen fra Svinninge Vejle (S.H. Andersen 1972, s. 82, fig. 6) og det tidligere omtalte, nye fund fra Horsens Fjord (fig. 3). Ud fra den formmæssige lighed med disse stykker er det rimeligt at henføre denne harpun til Ertebøllekulturen, det er sandsynligt, at den skal placeres blandt de tidlige Ertebølleharpuner.

Da så mange harpuner er enkeltfund, er de stykker, der er fremkommet ved udgravede og daterede Ertebøllebopladser af ekstra betydning. Blandt disse er tre harpuner (fig. 9-11) fra kystbopladsen Agernæs på Nordfyn (Jæerer 1988) (10), to harpuner (fig. 13) fra indlandsbopladsen 
Travenbrück LA 5 i Trave-dalen i Stormarn (Hartz 1997) og fire harpuner og et brudstykke (fig. 18 og 20) fra kystbopladsen Grube-Rosenhof i Holsten (Schwabedissen 1995) .

Harpunen, fig. 9, er et fint eksempel på en Ertebølleharpun af type A, der er fremstillet af en kronhjortetak. Den er velbevaret, men den yderste del af spidsen er lidt skadet. Omridset er ovalt med lige basis, og harpunen er symmetrisk om midtaksen; i profil er den lige. Overfladen er glatskrabet nær spidsen, men er ellers uforarbejdet. Ved spidsen, der ligger i midtaksen, ses en enkelt modhage af trekantet form. Tre centimeter fra basis er der boret et hul til snøren; hullets diameter er $0,3 \mathrm{~cm}$. Tværsnittet er halvcirkulært, og i profil er harpunen lige. Længden er $15 \mathrm{~cm}$; ved basis er bredden 2,5 cm, og tykkelsen er 0,5 cm. Harpunen er lidt kortere end hovedparten af de øvrige af denne type, men det kan skyldes, at den er opskærpet.

Denne harpun samt de to følgende (fig. 10-11) stammer fra udgravning af et in situ kulturlag på kystbopladsen Agernæs, hvis oldsager og C-14 dateringer viser, at den har været beboet i yngre Ertebølletid. Agernæsharpunens formmæssige lighed med de øvrige enradde Ertebølleharpuner af type A er med til at understrege typens tilknytning til Ertebøllekulturen og især dennes yngre fase (11).

Fra samme udgravning stammer også harpunen, fig. 10. Råmaterialet er spidsen af en kronhjortetak, der er skåret skråt igennem, således at gevirets yderste, uforarbejdede del danner harpunens spids. Den er spidsoval i omrids, men lidt usymmetrisk som følge af takkens svage krum-
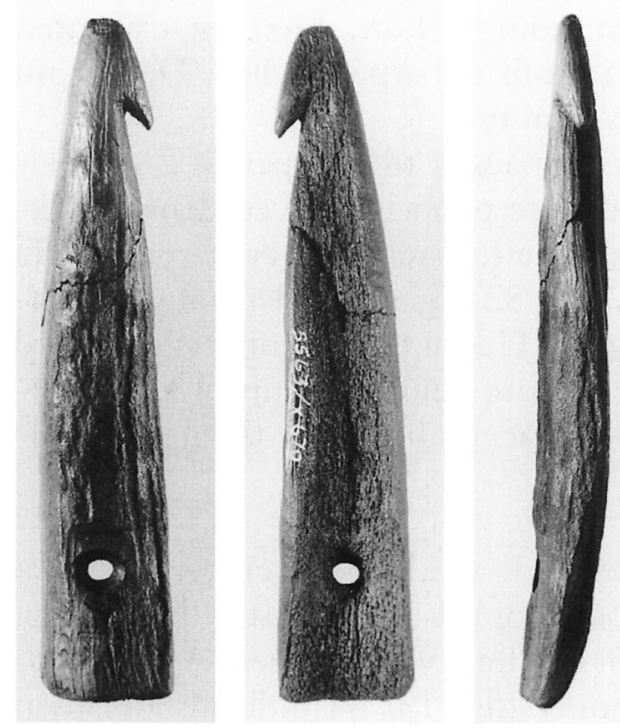

Fig. 9. Harpun af krondyrtak fra udgravning af Ertebøllebopladsen Agernæs, Nordfyn.

Foto: P. Dehlholm. 1:2.

Harpoon of red-deer antler from the excavation of the Ertebølle settlement Agernæs, north Funen. 
Fig. 10. Harpun fremstillet af spidsen af en kronhjortetak. Fra udgravning af Ertebøllebopladsen Agernæs, Nordfyn. Foto: P. Dehlholm. 1:2.

Harpoon produced from the tip of a red-deer antler. From the excavation of the Ertebølle settlement Agernæs, north Funen.
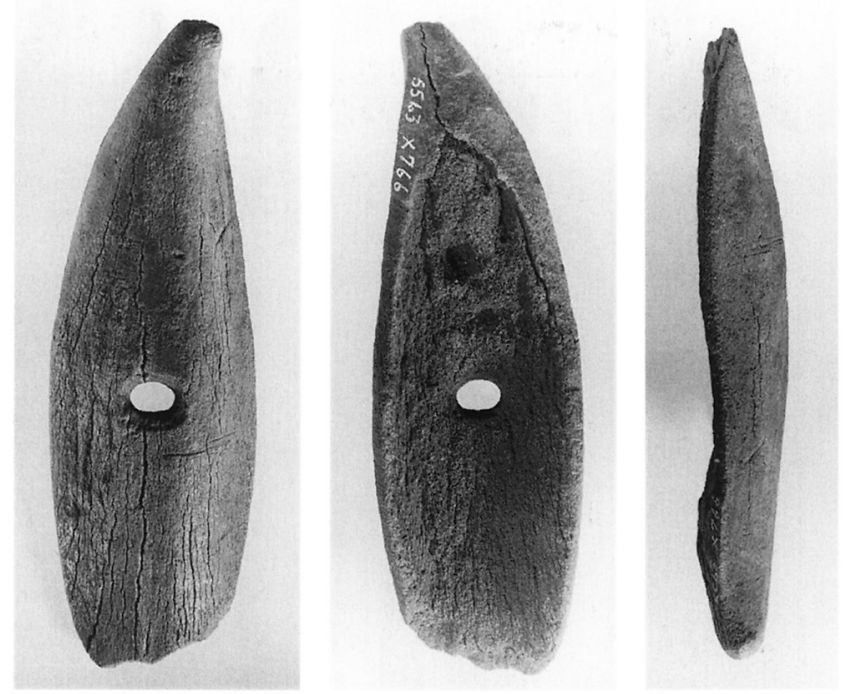

ning. Basis er rektangulær med lidt runde hjørner, og $5 \mathrm{~cm}$ fra denne ses et linehul med en diameter på $0,9 \mathrm{~cm}$ i harpunens midtakse.

Denne harpun er en variant, da nøjagtig tilsvarende stykker ikke kendes blandt de tidligere publicerede stykker. Formmæssigt er den nært beslægtet med de andre harpuner, hvor man har udnyttet spidsen af en uforarbejdet kronhjortetak - se bl. a. harpunen, fig. 2, og de tidligere publicerede stykker fra bl.a. Gudsø Vig (2 stk.) og Randersegnen (S.H. Andersen 1972, fig. 17-18). Stykket fra Agernæs er vigtigt, da dette fund viser, at denne variant nu med sikkerhed hører til i den yngre Ertebøllekulturs formforråd, hvilket vi ikke tidligere kunne sige på grundlag af de ældre fund. Længden er $15 \mathrm{~cm}$, største bredde (midtpå) er $5 \mathrm{~cm}$, og tykkelsen er $1 \mathrm{~cm}$.

Endelig kendes der også en toradet harpun fra denne boplads (fig. 11). Den er fremstillet af en hvalknogle. Omridset er symmetrisk og ovalt med lige kanter, der ender i en lidt uregelmæssig basis. Spidsen, der findes i midtaksen, er kort og trekantet, og dens yderste del er brækket af. Fra spidsen fortsætter kanterne i to korte, trekantede modhager, der også er symmetriske om længdeaksen. Syv en halv centimeter fra basis er der i længdeaksen et linehul med en diameter på ca. $0,7 \mathrm{~cm}$. Længden er 15,5 $\mathrm{cm}$, bredden er $5,4 \mathrm{~cm}$ og tykkelsen er $0,8 \mathrm{~cm}$. Tværsnittet er fladt med rundede kanter, og i profil er den lidt buet - antagelig fordi den er lavet af et ribben.

Harpunen må klassificeres som en helt opskærpet type D-harpun (S.H. Andersen 1983).

Dette fund er særligt vigtigt, fordi vi her står overfor den første toradede harpun fra en dansk boplads fra yngre Ertebøllekultur. 

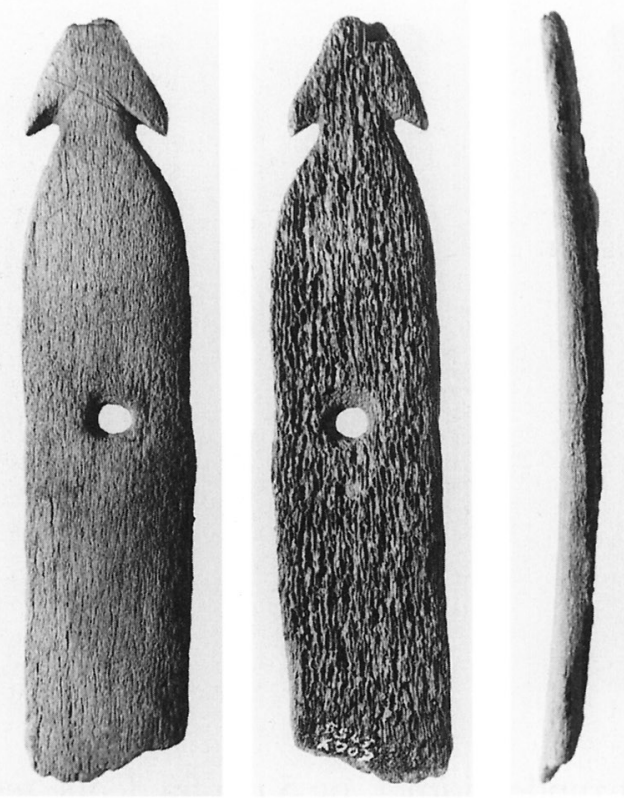

Fig. 11. Toradet harpun af hvalknogle. Fundet ved udgravning af Ertebøllebopladsen Agernæs, Nordfyn.

Foto: P. Dehlholm. 1:2.

Double-edged harpoon of whale bone. Found during the excavation of the Ertebølle settlement Agernæs, north Funen.

Fra den undersøiske Ertebølleboplads Ronæs Skov i Gamborg Fjord stammer et harpunbrudstykke, der også er fremstillet af en hvalknogle (fig. 12) (12). Spidsen er brudt af, og harpunen er også brækket tværs igennem linehullet, der sidder en anelse forskudt i forhold til midteraksen. Omridset er spidsovalt, og i profil er harpunen lidt buet - antagelig fordi den er lavet af et ribben. Ud fra sidekanternes forløb er det mest sandsynligt, at den kun har haft een modhage; hvis det er korrekt, er der
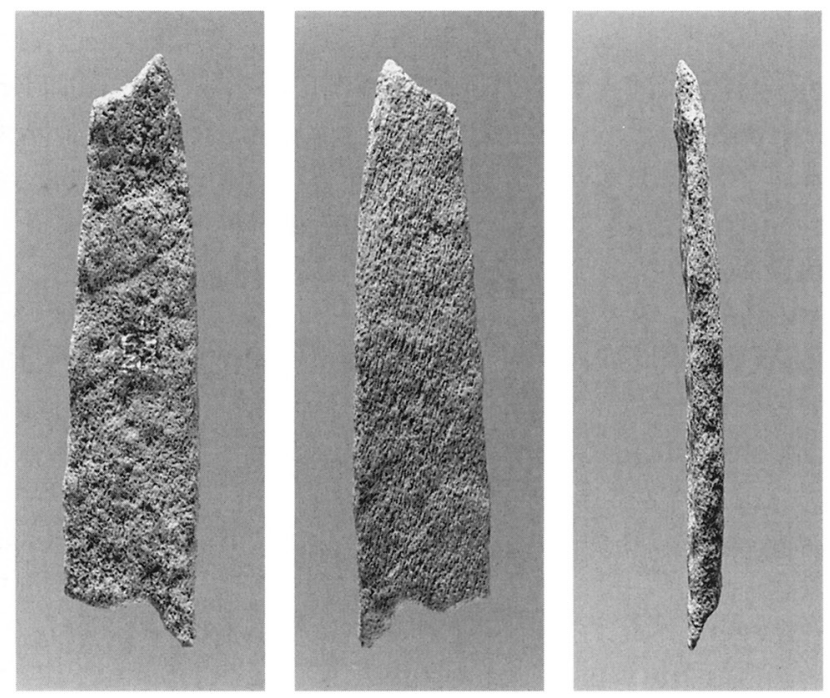

Fig. 12. Brudstykke af vandrullet harpun of hvalknogle. Fra undersøisk Ertebølleboplads ved Ronæs Skov, Gamborg Fjord, Vestfyn.

Foto: P. Dehlholm. 1:2.

Piece of water-worn harpoon of whale bone. From submarine Ertebølle settlement near Ronæs Skov, Gamborg Fjord, west Funen. 
Fig. 13. Toradet Ertebølleharpun af kronhjortetak; fra indlandsbopladsen Travebrück LA 5, i Holsten.

(Efter S. Hartz 1997). 1:2.

Double-edged Ertebølle harpoon of red-deer antler; from the inland settlement Travebrüick LA 5, in Holstein.

tale om en harpun af type A. Længden er 12,1 $\mathrm{cm}$, største bredde er $2,7 \mathrm{~cm}$, tykkelsen er 0,5 $\mathrm{cm}$, og linehullets diameter er $0,6 \mathrm{~cm}$.

Harpunen er fundet udskyllet af et undersøisk kulturlag, der både ad typologisk vej og ved hjælp af C-14 metoden er dateret til yngre Ertebøllekultur. Med forbehold for fundforholdene må harpunen - ligesom resten af dette fund - dateres til yngre Ertebøllekultur.

Fra udgravningen af indlands-Ertebøllebopladsen Travenbrïck LA 5 i Trave-ådalen, Kr. Stormarn (nær Lübeck) er der fundet en toradet harpun af type D (fig. 13). Råmaterialet er krondyrtak. Spidsen, der er lang og trekantet, ender i to modhager, der er lidt forskudt i

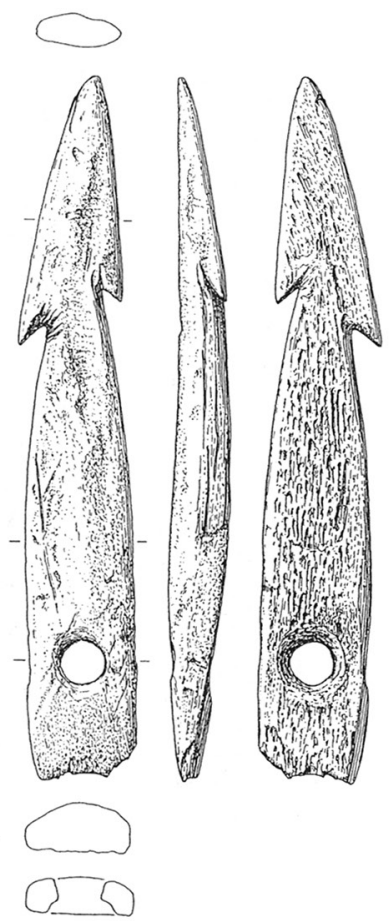
forhold til hinanden. I basis ses et linehul med en diameter på ca. $0,8 \mathrm{~cm}$. Længden er ca. 14 $\mathrm{cm}$, bredden ved basis er $2 \mathrm{~cm}$, og tykkelsen er ca. $0,9 \mathrm{~cm}$. Tværsnittet er halvcirkelformet.

Der findes ingen nære paralleller, men den ligner harpunen fra Agernæs på Nordfyn (fig. 11). Trave-harpunens form tyder på, at den også er helt opskærpet og oprindelig har været af samme type som stykket fra Fønsskov (S.H. Andersen 1983).

Fra samme bopladsudgravning er også fremkommet spidsen af en enradet harpun (?) med to korte modhager (også af hjortetak). Da der er tale om et brudstykke, kan det ikke med sikkerhed afgøres, om der er tale om en harpun, men det er dog mest sandsynligt. I bekræftende fald er der tale om spidsen af en A-harpun.

Disse harpuner er fundet ved systematisk bopladsudgravning af en indlands-Ertebølleboplads med to bebyggelsesfaser, der er daterede til hhv. 5400-5200 f. Kr. og 4200-4100 f. Kr. ( kal.) - begge faser ligger inden for den slesvig-holstenske Ertebøllekulturs tidsramme (Hartz 1997, s. 183-184).

Fra Skåne er der også i de seneste år fremkommet flere veldaterede fund af Ertebølleharpuner. Fra bopladsen Skateholm IX foreligger således et af de karakteristiske basisstykker, som er et resultat af, at harpunen er brækket tværs igennem linehullet (fig. 14,2).

I kulturlaget på Ertebøllebopladsen Skateholm I er der fundet spidsen 

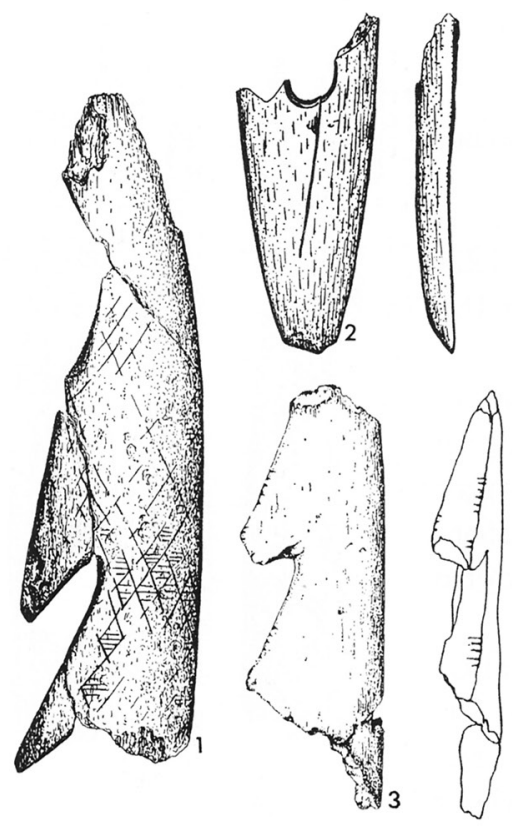

Fig. 14. Ertebølleharpuner fra skånske Ertebøllebopladser. 1) er fra Skateholm I og er lavet af en ornamenteret hjortetaksøkse (genbrug), 2) er basisdel af brækket harpun fra Skateholm IX og 3) er fra bopladsen Bredasten.

(Efter Larsson 1986 og Larsson 1988). 1:2.

Ertebølle harpoons from Scanian Ertebølle settlements. 1) is from Skateholm I and made from a decorated antler axe (re-utilized), 2) is the basal part of a broken harpoon from Skateholm IX and 3) is from the Bredasten settlement.

af en typisk harpun af type $\mathrm{B}$, hvis overflade er dækket af et fint indridset netmønster af rhomber, hvoraf nogle er udfyldt med tynde tværstreger (fig. 14,1). Ornamentikkens forløb viser, at harpunen er fremstillet af en mønstret hjortetaksøkse, og der er således tale om et eksempel på "genbrug" af hjortetaksøkser, hvilket der også kendes et par tilfælde af fra Danmark (Tudeå og Åmosen). På samme måde som harpunen fra Skateholm er det danske stykke fra Tudeå også lavet af en mønstret hjortetaksøkse (S.H. Andersen 1976, s. 11-16). Kulturlaget på Skateholm I er

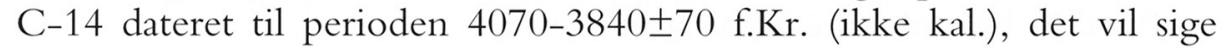
ældre Ertebøllekultur (Lu-1853 og Lu-1848) (Larsson 1984, s. 8).

På Ertebøllebopladsen Bredasten lidt længere østpå end Skateholm er der også fundet et fragment af en harpun - antagelig af type B (fig. 14,3) (Larsson 1986, s. 36 og fig. 10,b). En nøjagtig datering af denne boplads er imidlertid omgærdet med usikkerhed, da de foreliggende C-14 resultater (yngre Ertebøllekultur) ikke stemmer overens med den typologiske datering (ældre Ertebøllekultur). Det står dog fast, at fundet tilhører Ertebøllekulturen, og forfatteren hælder selv til en datering i ældre Ertebøllekultur (Larsson 1986, s. 39).

Fra grav IV på den lidt ældre Ertebøllelokalitet Skateholm II er der fundet en harpun som gravgods (fig. 15,1) (Larsson 1988a, s. 66, fig. 4 og s. 68, fig. 5; 1988b, s. 138). Der er tale om en variant af en type A-harpun. Den er lavet af krondyrtak og er enradet og med spidsovalt omrids og spidsoval - tungeformet basis. Ved den ene kant ses fire modhager af smal - trekantet form skiftende med dybe indskæringer; under den nederste modhage ses et usymmetrisk placeret linehul (nær kanten), hvor den danner et lille "knæk" .

Sidstnævnte stykke er vigtigt, både fordi den igennem sin fundsammenhæng kan dateres til den ældre/ældste Ertebøllekultur; således viser 
Fig. 15.

Ertebølleharpun fra jordfæstegrav på gravpladsen Skateholm II (ældre Ertebøllekultur).

Harpunen er dekoreret med et fint indridset mønster af krydsskravering på modhagernes forkant (1) og Tudeå, Vestsjælland (2); den sidstnævnte er fremstillet af en mønstret hjortetaksøse.

(Efter L. Larsson 1988 og S.H. Andersen 1975). $1: 2$.

1) Ertebølle harpoon from inhumation grave at the Skateholm II cemetery (early Ertebølle culture). The harpoon is decorated with a finely incised pattern of crosshatching on the front edge of each barb. 2) Ertebølle harpoon from Tudeå, west Zealand, made from a decorated antler axe.
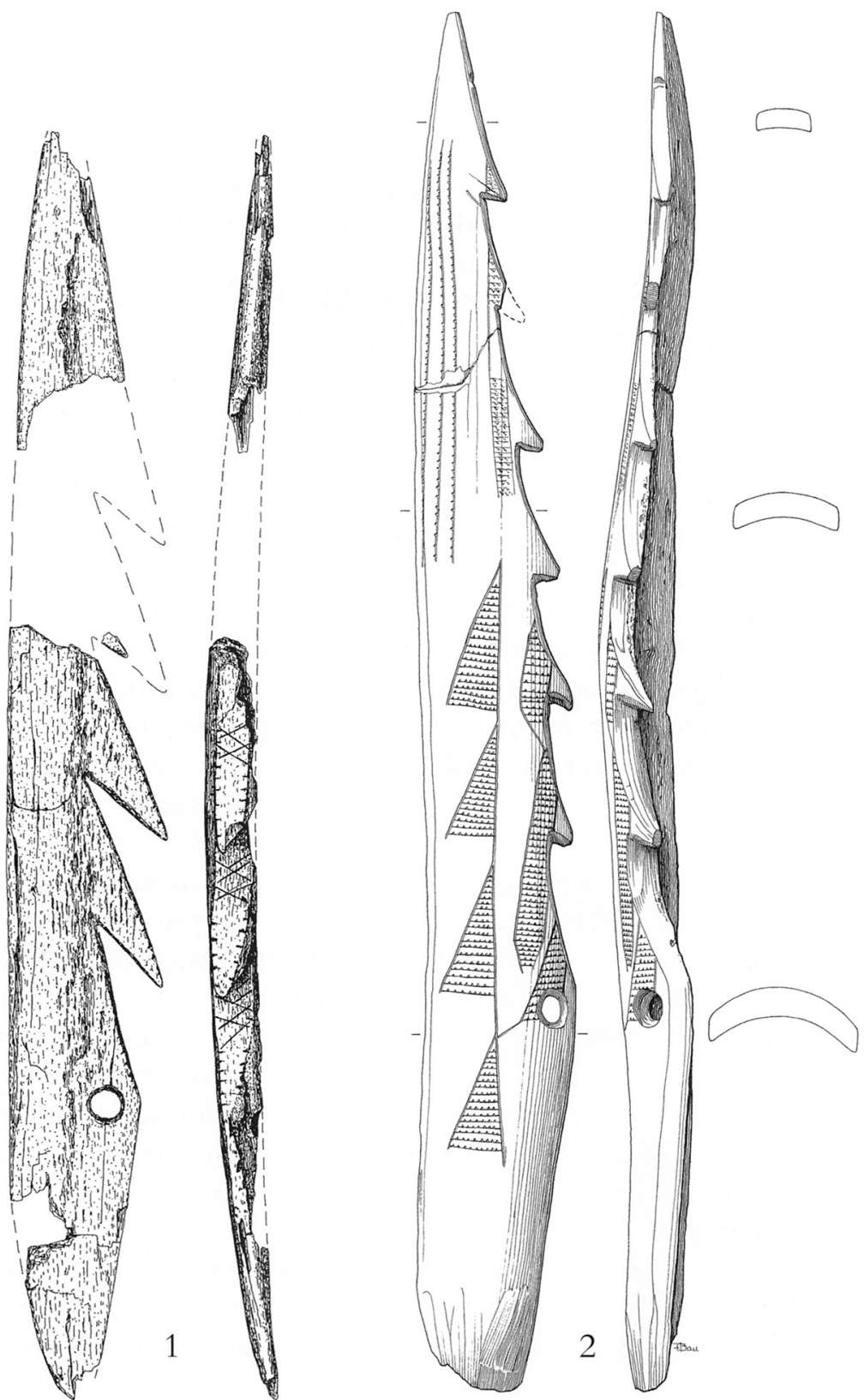

C-14 dateringerne, at kulturlaget på Skateholm II hører til i tidsrammen 4640-4430 \pm 70 f.Kr. (ikke kal.) (Lu-2113 og Lu-2115) (Larsson 1984, s. 12), og samtidig fordi det er første gang, at en Ertebølleharpun indgår i en tydelig rituel sammenhæng (som gravgods).

Denne harpun afviger fra de typiske Ertebølle harpuner af type A ved, at den har flere modhager og et usymmetrisk placeret linehul, hvor kanten danner et lille "knæk". Derimod ligner den meget den tidligere publicerede harpun fra Tudeå, der har seks modhager og et tilsvarende 
usymmetrisk placeret linehul ud for et fremspring på sidekanten (fig. 15,2). Tudeåharpunen blev på grundlag af motiver og teknik dateret til yngste Kongemosekultur / ældste Ertebøllekultur (S.H. Andersen 1976, s. 11-16 og fig. 1-2). De to dateringer er i god overensstemmelse med hinanden, hvorfor vi nu med sikkerhed kan placere denne harpuntype på overgangen mellem Kongemose- og Ertebøllekulturen eller den ældste Ertebøllekultur.

Ud fra vor nuværende viden er der altså tale om den ældste, daterede harpuntype.

Ser vi på de skånske harpuner under et, kan de altså alle med sikkerhed henføres til Ertebøllekulturen, men i forhold til de danske harpuner kan der iagttages en interessant forskel, idet tre af de skånske harpuner har serier af korte, indskårne tværstreger på kanterne af modhagernes forside, fig. 14,5; på harpunen fra grav IV på Skateholm II ses der yderligere indridset en krydsskravering på den del af modhagerne som vender fremad. Denne type ornamentik er helt ukendt i Danmark, og selvom det skånske materiale endnu er lille, tyder forskellen i udsmykningen på andre traditioner i Skåne end i Danmark.

En tilsvarende krydsskravering på

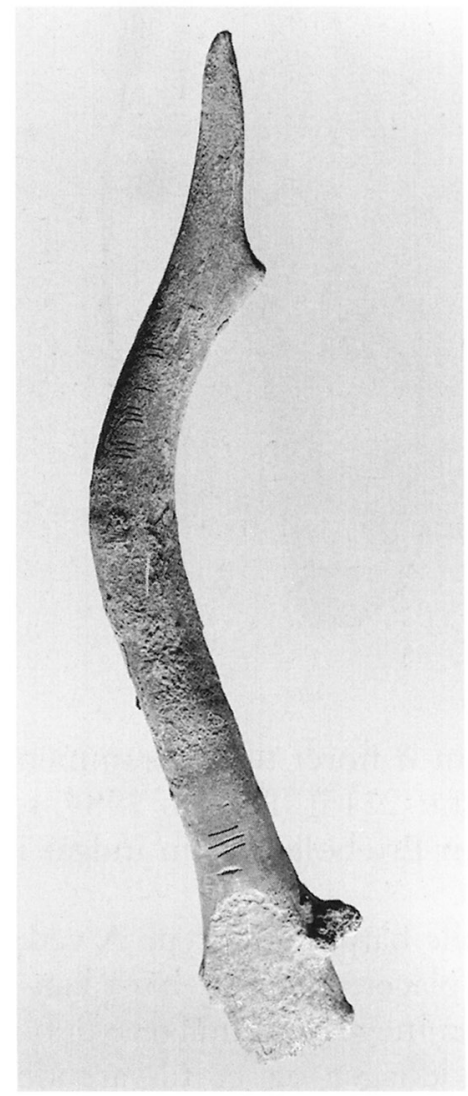
modhagens forkant ses imidlertid også på en B-harpun fra Ertebøllebopladsen Ralswieck-Augustenhof på Rügen (Gramsch 1973, s. 160, Taf. 55,4).

Endelig skal det nævnes, at der ved Ravlunda nær Simrishamn i Sydøstskåne også er fundet et brudstykke af en stærkt vandrullet harpun - antagelig af Ertebølletype A (Larsson 1987, s. $62-63$ og fig. $1-2)$.

Harpunen, fig. 16, er også et nyt fund, der stammer fra den systematiske udgravning af Ertebøllebopladsen Lystrup Enge (S.H. Andersen 1996). Der er tale om en harpun af type C, fremstillet af en svajet rådyrtak (S.H. Andersen 1972, s. 99-102).

Fig. 16. Harpun af rådyrtak. Fundet ved udgravning af Ertebøllebopladsen Lystrup Enge. Harpunens overflade er glatpoleret og der ses rester af geometrisk ornamentik af fine, indridsede streger. Foto: P. Dehlholm. 1:2.

Harpoon of roe-deer antler. Found during excavation of the Ertebølle settlement Lystrup Enge. The surface of the harpoon is smoothly polished, and remains are seen of geometrical ornament of fine incised lines. 


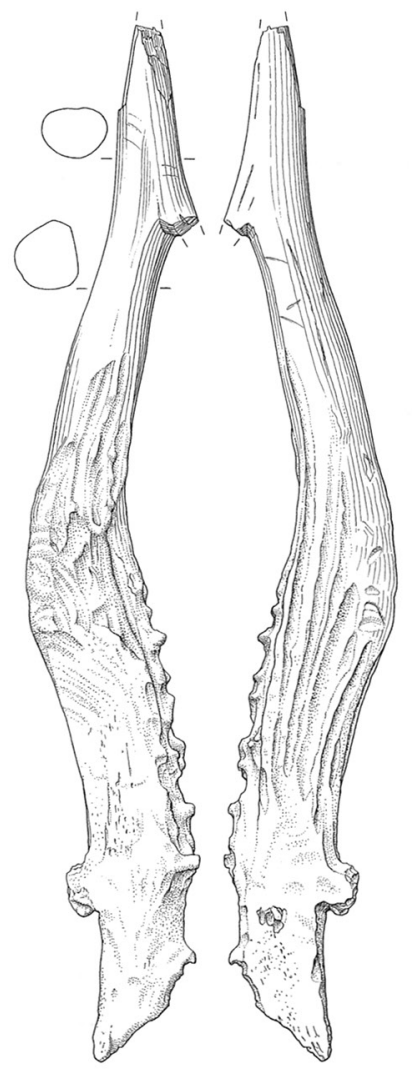

Fig. 17. Harpun af rådyrtak. Fundet ved udgravning af undersøisk Ertebølleboplads ud for Ronæs Skov i Gamborg Fjord, Vestfyn. Fra denne boplads, der ligger ved et af de farvande, hvor der har været drevet jagt på marsvin helt på til vore dage, kendes et storre antal knogler af sæl og marsvin samt et usædvanlig stort antal "spæklamper" Tegning: Orla Svendsen. 1:2.

Harpoon of roe-deer antler. Found during excavation of a submarine Ertebølle settlement off Ronæs Skov in Gamborg Fjord, west Funen. From this settlement, situated in waters where porpoises have been hunted right up to the present day, a large number of bones of seal and porpoise, and an unusually large number of "blubber lamps" have been recovered.

Stykket er velbevaret, men en splint af basis er slået af ved udgravningen. Den er forarbejdet således, at takkens spids er bibeholdt, og det samme galder lidt af en sidegren, der har fungeret som modhage. Basis er forarbejdet til to modstående, skrå anlæegsflader ved hvis kanter, der er efterladt lidt af rosenkransen til linefæste. Længden er 20,5 cm, tykkelsen er ca.1,5 cm midtpå, og bredden er ved basis ca. $2,5 \mathrm{~cm}$.

Harpunen er bemærkelsesværdig, fordi den - i modsætning til normen for denne harpungruppe - er helt glatskrabet og poleret. Svage ridser i overfladens bedst bevarede partier viser, at den også har været mønstret, men motivet kan desværre ikke bestemmes.

Denne harpun er fremkommet ved systematisk udgravning af en boplads, der både typologisk og ved hjælp af C-14 dateringer er henført til xldre Ertebøllekultur, 5310-4940 f.Kr. (kal.) (K-4052-4055) (S.H. Andersen 1997, s. 16); denne dateringsramme gælder derfor også harpunen, der samtidig er vigtig, fordi der ikke er andre harpuner i dette store Ertebøllefund, der imidlertid omfatter talrige knogler af havpattedyr (S.H. Andersen 1997, s. 10). Det kan i øvrigt tilføjes, at der heller ikke kendes affald fra harpunfremstilling fra denne boplads.

Af harpuner af type $\mathrm{C}$ er der kun ét tidligere fund, som også er glatpoleret og mønstret, nemlig harpunen fra Horsens Fjord (S.H. Andersen 1972, fig. 34a og s. 101). I overensstemmelse med den nære formlighed med det nye fund fra Lystrup, kan Horsens Fjord-harpunen nu også med større sikkerhed end tidligere dateres til ældre Ertebølletid.

Det er bemærkelsesværdigt, at de to eneste danske harpuner med ornamentik af denne type begge stammer fra østjyske lokaliteter med en indbyrdes afstand på ca. $45 \mathrm{~km}$. 
Af andre nye fund af C-type harpuner kan nævnes, at der ved systematisk udgravning af Ertebøllebopladsen, Ronæs Skov (Gamborg Fjord), også er fremkommet en meget velbevaret harpun af rådyrtak, hvis yderste spids dog er brækket (fig. 17) (12). Den er lavet af en svajet rådyrtak, der oprindelig har haft to sprosser. Den gren, som har siddet nærmest spidsen, er fjernet, og dens basis er forarbejdet til en modhage, mens den anden spros er skåret væk. Basis er forarbejdet $\mathrm{i}$ den hårde knoglemasse mellem rosen og pandebenet og består af to modstående og skrå anlægsflader $\mathrm{i}$ samme plan som modhagen; på begge sider har man ladet en smule af rosenkransen sidde tilbage for at give et godt freste til fanglinen. I dag har harpunen en længde på $21 \mathrm{~cm}$, og ved basis er bredden ca. $2,5 \mathrm{~cm}$.

Harpunen er fundet ved en systematisk bopladsudgravning og stammer fra en aflejring, der er C-14 dateret til at være samtidig med eller yngre end 4215-4015 f. Kr. (kal.) (K-5731), d.v.s. yngste Ertebølletid.
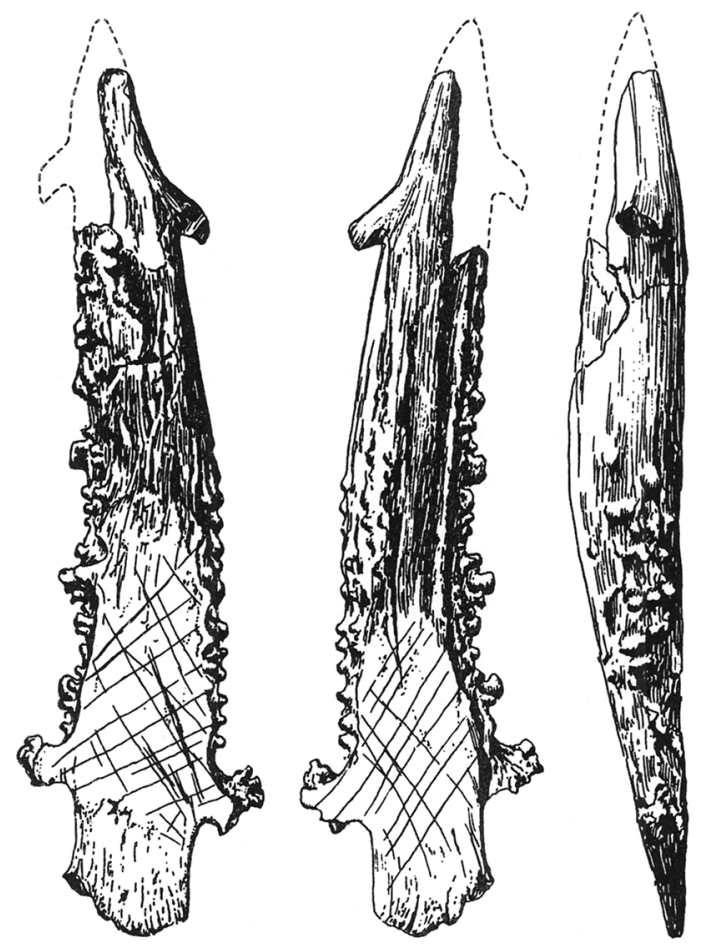

Fig. 18. Rådyrtakharpuner fra Ertebøllebopladsen GrubeRosenhof i Holsten.

(Efter Schwabedissen 1994). 1:2.

Roe-deer antler harpoons from the Ertebølle settlement Grube-Rosenhof in Holstein.
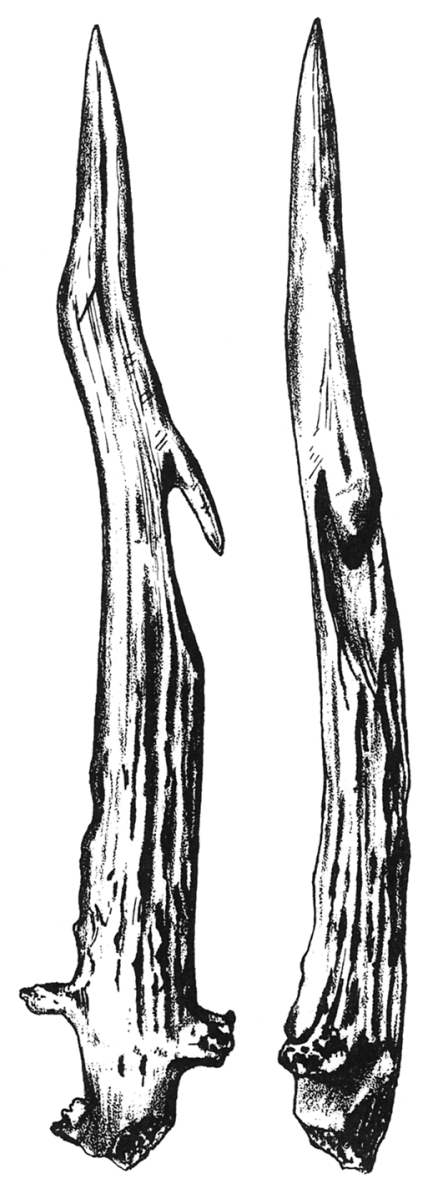
Fig. 19. Harpun af rådyrtak med geometriske mønstre bestående af tynde, indridsede streger i den glatpolerede overflade. Fra Odermundingen, Nordpolen. (Efter Czarnecki 1976). 1:2.

Harpoon of roe-deer antler with geometric patterns consisting of thin, incised lines in the smoothly polished surface. From the mouth of the Oder, north Poland.
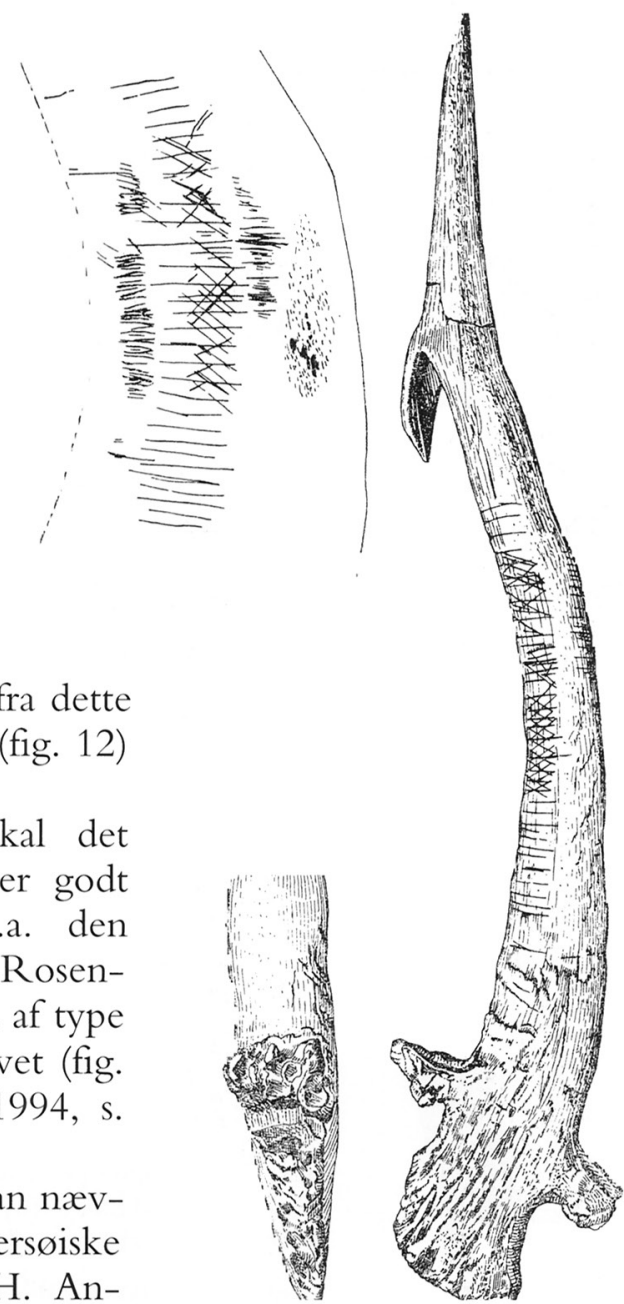

Der foreligger altså to harpuner fra dette fundsted, henholdsvis A-harpunen (fig. 12) og rådyrtakharpunen (fig. 17).

For fuldstændighedens skyld skal det tilføjes, at denne datering stemmer godt med dateringsresultaterne fra bl.a. den nordtyske Ertebølleboplads Grube-Rosenhof, hvor der er fundet 4 nye fund af type C-harpuner, af hvilke to ses gengivet (fig. 18) (Schwabedissen 1972, s. 7-8;1994, s. 373-376 og Taf. 15).

Af andre nye type C-harpuner kan nævnes fund fra henholdsvis den undersøiske Ertebølleboplads Tybrind Vig (S.H. An-

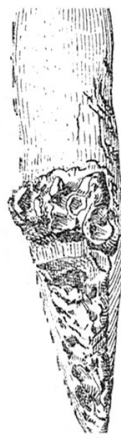
dersen 1985) og Tudse Hage nær Skælskør (Lotz 1996). Det sidstnævnte stykke er bemærkelsesværdigt derved, at basis ikke er forarbejdet til to skrå flader (som ved de øvrige stykker i denne gruppe), men derimod fremstår med takkens oprindelige rosenstok og basis. Denne harpun kan derfor enten opfattes som en variant, der har haft en afvigende skæftning i forhold til de øvrige, eller også er der tale om et stykke, hvis basis ikke er blevet færdigbearbejdet (Lotz 1996, s. 12) (13). Det kan tilføjes, at en af harpunerne fra Grube-Rosenhof i Holsten har en tilsvarende, tyk basis.

Uden for Danmark skal også nævnes et enkeltfund fra Oderens munding ved Szczecin (Czarnecki 1976). Det er den østligste (og helt isolerede) forekomst af denne harpuntype (fig. 19). Denne harpun har glatskrabet overflade, hvori der ses et fint indskåret mønster af korte, parallelle streger og krydsskravering. Da der ikke findes noget lokalt referencemateriale, er det vanskeligt at vurdere dens kulturelle tilhørsforhold, men indtil videre 


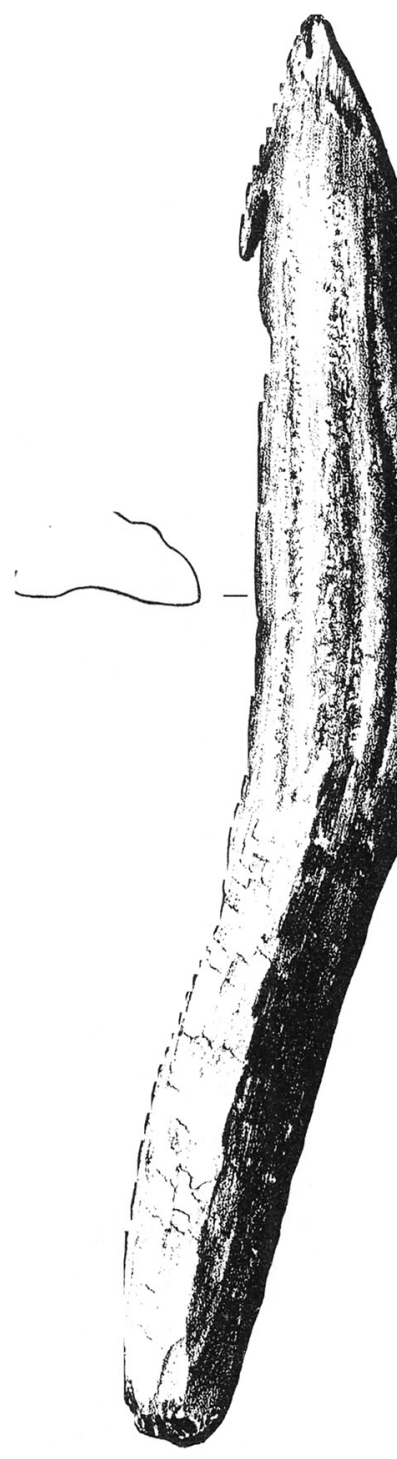

Fig. 20. Eksempler på store, toradede kronhjortetaksharpuner og basisstykke med knop af type D fra nordtyske Ertebøllebopladser. (Efter H. Schwabedissen 1994). 1:2.

Examples of large, double-edged red-deer antler harpoons of type D from north German Ertebølle settlements.

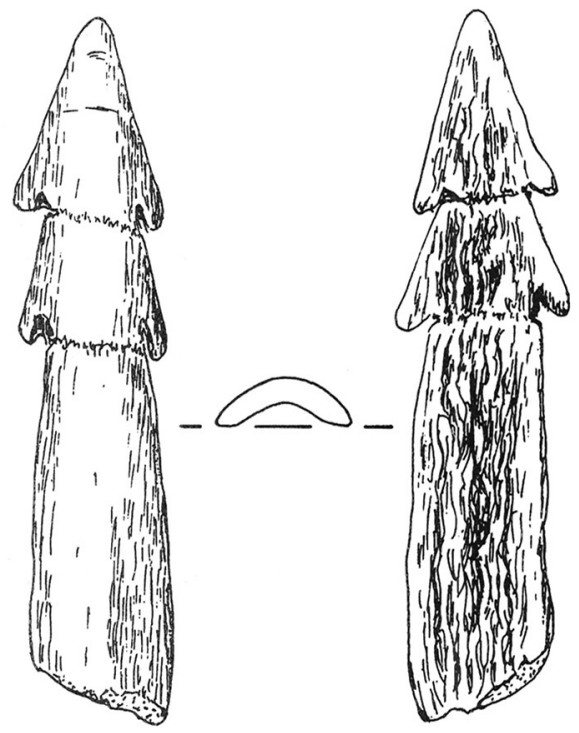


er de nærmeste paralleller fra Østjylland, hvor der såvel med hensyn til mønstringsteknik, motiver og komposition ses et nært slægtskab med Charpunerne fra Horsens Fjord og Lystrup Enge. Det kan derfor med forsigtighed antages, at Podjuch harpunen tilhører ældre Ertebøllekultur, men hvorledes man skal forklare denne lighed og harpunens forekomst så langt mod sydøst, må indtil videre stå hen i det uvisse.

Af andre nye bopladsfundne harpuner kan nævnes et brudstykke af en type D-harpun fra Ertebøllebopladsen, Grube-Rosenhof i Holsten (fig. 20) (Schwabedissen 1995, Taf. 15,4). Der er tale om et basisstykke, der opefter er brækket, og ved hvis ene kant, der er udskåret en firkantet "tap" til snøren. Dette træk findes kun på D-harpunerne, og der er ingen tvivl om, at det er et brudstykke af en stærkt opskærpet harpun af samme slags, som de tidligere publicerede D-harpuner fra Fønsskov, Kiel Ellerbek (Mestorf 1904) og Marienbad nær Neustadt i Holsten (Schwabedissen 1994, Taf. 7,3) (fig. 20).

\section{Harpuntyper}

Med udgangspunkt i de seneste fund og sammenholdt med de tidligere publicerede står det nu klart, at Ertebøllekulturen har rådet over fire hovedformer af harpuner, henholdsvis type A, B, C og D - hvortil kommer et antal varianter, - især af type A (fig. 21).

Type $A$ er enradede harpuner af kronhjortetak eller hvalknogle med et lige, symmetrisk og spidsovalt omrids. Odden er spids-trekantet, og ved den ene kant er udarbejdet en-tre modhager. Basis er i de fleste tilfælde lang og tungeformet, men enkelte er kortere og med et mere rektangulært omrids; i midtaksen er der boret et linehul ca. $5 \mathrm{~cm}$ fra basisafslutningen, men afstanden kan variere noget. Længden af de hele stykker veksler mellem 12,7 og $27 \mathrm{~cm}$ og bredden mellem 1,8 cm og $4 \mathrm{~cm}$. Tykkelsen er mellem $0,8 \mathrm{~cm}$ og $1,5 \mathrm{~cm}$.

Type $B$ er enradede harpuner af kronhjortetak med krumt omrids og enfire modhager ved den konkave længdekant. Basis er lang og tungeformet, og i midtaksen er der et linehul; i et tilfælde ses et dybtgående hak under modhagerne til fastbinding af snøren. Længden veksler mellem 17 $\mathrm{cm}$ og $20 \mathrm{~cm}$, mens bredden er fra $3,0 \mathrm{~cm}$ til $3,5 \mathrm{~cm}$. Tykkelsen ligger mellem $0,8 \mathrm{~cm}$ og $1,6 \mathrm{~cm}$.

Type C er en- eller toradede harpuner af rådyrtak med svajet længdeakse. Gevirets sidegrene er enten forarbejdede til krogformede modhager eller er helt bortskåret, og basis er udformet som to skrå flader, der løber sammen $i$ en spids vinkel. Ved basis har man bibeholdt rester af rosenkransen, der så har fungeret som linefæste; i et tilfælde ses der en gennemboring $\mathrm{i}$ basis, og en anden viser en indskåret fure til snøren. Længden 


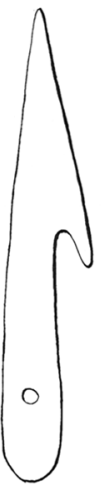

A

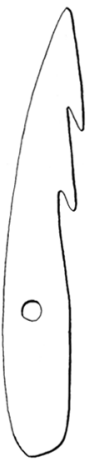

B

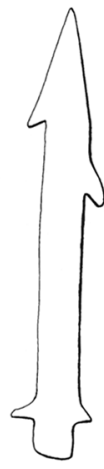

C
Fig. 21. Hovedtyperne af Ertebøllekulturens harpuner. Tegning: Louise Hilmar.

The main types of Ertebølle culture harpoons.

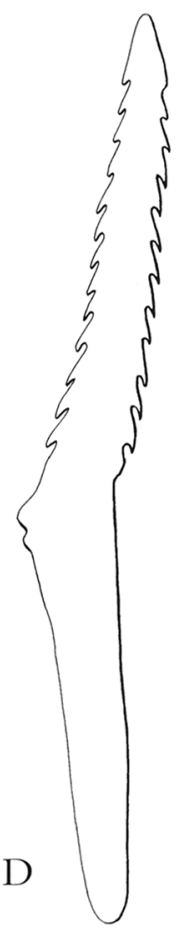

ligger fra $14 \mathrm{~cm}$ til $19 \mathrm{~cm}$, og bredden er fra $2,5 \mathrm{~cm}$ og $4 \mathrm{~cm}$. Tykkelsen er på ca. $2-3 \mathrm{~cm}$.

Type D er toradede harpuner af kronhjortetak med en kort, bred og trekantet spids og mange små, tætsiddende og korte modhager. Harpunerne er lige eller svajede i længden, og basis er lang og tungeformet. Et karakteristisk træk ved denne type er, at der i flere tilfælde er udarbejdet en knop til fæste for fanglinen ved den ene kant, men nogle eksemplarer har dog et boret hul til fangline i stedet. Den kendte harpun, der er fundet på havbunden ud for Føns-halvøen på Vestfyn giver et godt indtryk af, hvor store disse harpuner har været i ubeskadiget tilstand; den måler ca. 32,1 cm i længden og er ca. $4,7 \mathrm{~cm}$ bred.

Endelig er der en harpun-gruppe, som foreløbig kun udgøres af nogle fă fund fra henholdsvis Skateholm II, Tudeå og evt. Klintholm. Disse stykker - der ser ud til at være de ældste - er enradede med en serie korte, trekantede modhager langs den ene kant; basis er lang og tungeformet, og har et boret hul, som er placeret forskudt i forhold til midtaksen. Ud for linehullet danner kanten en fremspringende "skulder". Tudeå harpunen er $33 \mathrm{~cm}$ lang (de øvrige A- harpuner er ca. 12-27 cm), dens bredde er 3,4 cm (1,8-4 cm), og dens basis er 8,8 cm, hvor A- harpunerne ligger mellem $2-6 \mathrm{~cm}$ ).

En sammenligning mellem harpunerne fra Tude Å og Skateholm II og de øvrige (og yngre) Ertebølleharpuner tyder på, at modhagernes størrelse og antal er træk, der varierer i løbet af tiden, således at de ældste harpuner karakteriseres ved adskillige og forholdsvis små modhager kombineret med et usymmetrisk placeret linehul, der så gradvis ændres til harpuner med en enkelt eller færre og større modhager samtidig med at linehullet er symmetrisk placeret og basis er kortere (S.H. Andersen 1976, s. 15-16). Hvor denne form-udvikling tidligere kun kunne skitseres, må den nu siges at være sikrere begrundet. 
Da det er den ældste harpunform, kan den forsøgsvis benævnes type A-1.

For samtlige typer gælder, at de udviser stor variation; især er der forskel på længden og antallet af modhager. Som en grundregel gælder, at de harpuner, som ikke er fremkommet på en boplads, men derimod er tabt under havjagt, altid er de længste og samtidig har flest modhager. Som følge af slid og opskærpning er harpunerne gradvist blevet kortere og har samtidig fået færre modhager. Det har derfor i flere tilfælde været vanskeligt at afgøre med sikkerhed, om der evt. er tale om en type A harpun eller en variant af type $\mathrm{A}$, når harpunen er helt opskærpet. Også de toradede harpuner kan være helt opskærpede; en sammenligning af harpunen fra Kiel-fjord med harpunen fra Føns viser klart, hvor omfattende opskærpningen har været i forstnævnte tilfælde.

Til slut skal nævnes en lille gruppe af mulige harpuner eller harpunlignende redskaber, der dog ikke kan rubriceres i de ovenfor beskrevne typer (fig. 22). Blandt disse er det velkendte, 30,2 cm lange knivformede redskab fra Bloksbjerg, der er forsynet med fine takker langs den ene sidekant (Westerby 1927, s. 110 og fig. 35). Ved basis, hvor det er brækket i oldtiden, er der spor af et øje til snøre, og våbnet opfylder dermed definitionen for en harpun. Den er enestående i det nordiske fundstof, og har ved en ny undersøgelse vist sig at være fremstillet af den ene halvdel af spidsen af "sværdet" fra en sværdfisk (Xiphias gladius L.). På begge sider er det udsmykket med tæt krydsskravering, der dækker over et ældre, stormasket netmønster (Petersen 1996, s. 16-17). Ud fra fundforholdene må det henføres til yngre Kongemosekultur. Fra samme fundlag på Bloksbjerg stammer den forreste del af en benspids (fremstillet af en mellemfodsknogle af krondyr) med tre-fire små, trekantede modhager langs den ene kant. Redskabet, der i dag er 16,7 cm langt, er brækket nedefter, hvorfor det ikke kan afgøres, om der er tale om en harpun af en særform eller ej; umiddelbart er der en vis lighed med den jævngamle harpun fra Tudeå (fig. 15,2) (Westerby 1927, s. 105 og fig. 32).

Fra Kiel-Ellerbek er der et $36 \mathrm{~cm}$ langt, 2,2 cm tykt, spidst og kegleformet våben af kronhjortetak i hvis tykke ende, der ses et hul (Schwabedissen 1994, Taf. 7,1). Selvom denne genstand også er unik i Ertebøllekulturens fundstof, tyder den korte, afrundede basis og linehullet på, at der er tale om en særform af harpunerne. Da dette våben er fremkommet ved opgravning/opmudring fra de undersøiske Ertebøllebopladser i Ellerbek-området er der ingen absolut garanti for, at redskabet tilhører Ertebøllekulturen, om end det er sandsynligt.

Fra et usystematisk Ertebøllefund fra Marienbad ved Neustadt (Holsten) kendes en meget særpræget harpun, som også er uden paralleller. Råmaterialet er hvalknogle eller hjortetak. Harpunen er enradet med en enkelt, lidt krogformet modhage nær spidsen. Basis er brækket af, men ved sidekanterne er der udskåret et par smalle, lidt fremspringende kan- 


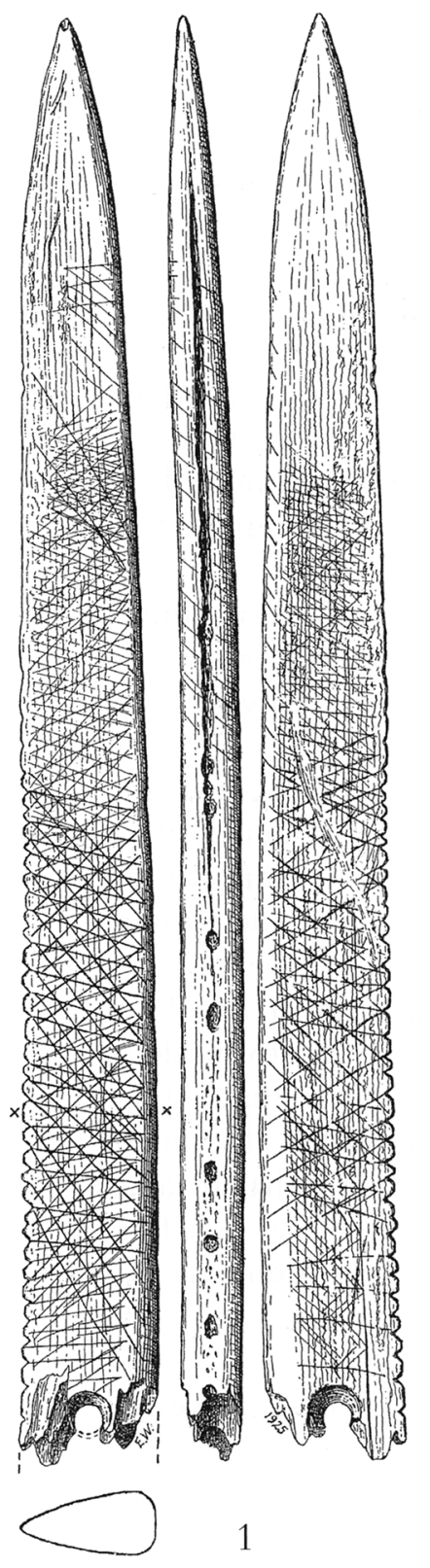

Fig. 22. Særformer af harpuner fra hhv. Bloksbjerg, Østsjælland (12), Kiel-Ellerbek (3) og Marienbad, Holsten. (Efter Westerby 1927 og

Schwabedissen 1994). 1:2.

Special forms of harpoon from Bloksbjerg, Kiel-Ellerbek and Marienbad, respectively.

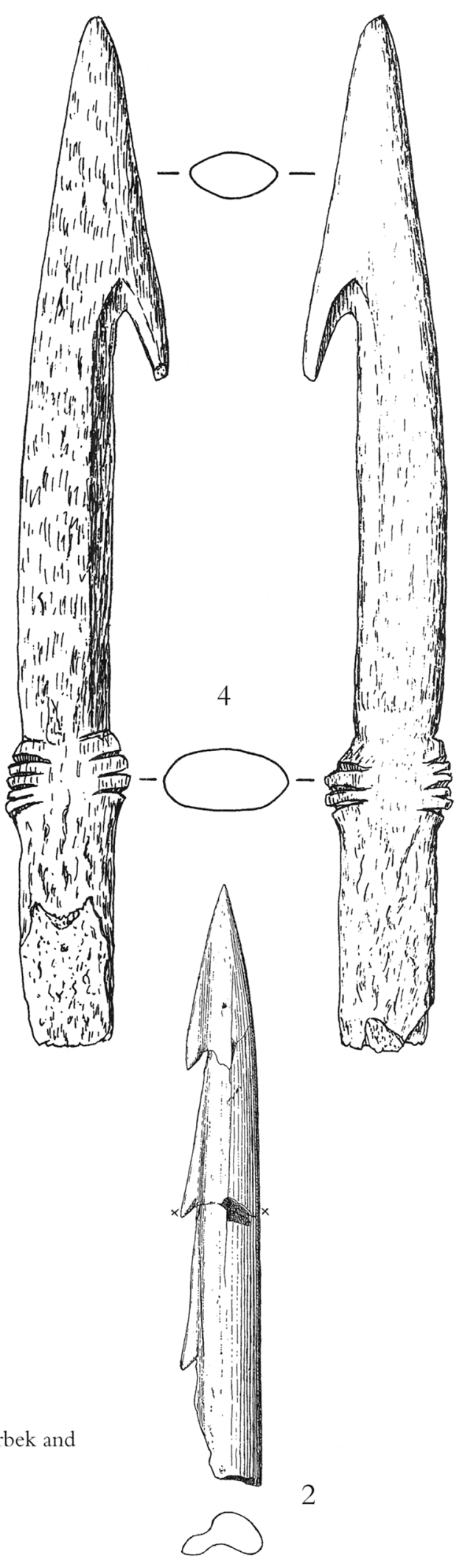


ter, der givet har skullet sikre fanglinens fæste; dette punkt minder meget om basisudformningen af Ertebølleharpunerne af type C, men fundforholdene gør det usikkert, om denne harpun tilhører denne kultur, eller evt. et yngre tidsafsnit af oldtiden.

I modsætning til Ertebølleharpunerne er de neolitiske harpuner meget ofte af (tam-)dyreknogle, de er gennemgående kortere, og de har en udpræget firkantet basis, som ofte er kombineret med en "afsat" skulder under den sidste modhage; samtidig har de et usymmetrisk placeret linehul.

Med den nye, mere præcise typebeskrivelse af Ertebølleharpunerne er det også klart, at dateringen af nogle af de tidligere publicerede stenalderharpuner må ændres fra Ertebøllekultur til yngre stenalder (S.H. Andersen 1972, s. 82 og 85, fig. 8; 1976, s. 17-20 og fig. 3; s. 20-21, fig. 4).

\section{Udbredelse}

De fire harpuntyper findes i Danmark, Sydsverige, Nordtyskland og Nordpolen (fig. 23-24).

Det er karakteristisk for de enkelte harpuntyper, at de har en regional udbredelse.

Således findes A-typen overvejende vest for Storebælt, det vil sige det jysk-fynske område, men enkelte er dog også fundet på Sjælland (fig. 23).

B-typen har derimod en østlig udbredelse og kendes kun fra Sjælland, Skåne og Rügen (Larsson 1984, Petzch 1928, Gramsch 1973, s. 160, Taf. 55,4) (fig. 23).

C-harpunen er indtil videre ikke fundet i Nordjylland, og kendes heller ikke fra Skåne. Ellers er den til stede i resten af Danmark og Nordtyskland (Petzsch 1928, Gramsch 1973, s. 160, Taf. 55,1, Schwabedissen 1972, Abb.3,5; 1995, s. 396-397, Taf. 15,1 og Taf. 16,5) (fig. 24). En enkelt harpun er som nævnt fundet i Oder-mundingen nær byen Podjuch (ved Szczecin) - ved Ertebøllekulturens østligste grænse (Gramsch 1973, s. 169, Karte 6, Czarnecki 1976) (fig. 24).

Det nuværende fundbillede viser, at denne form især er almindelig omkring den sydvestlige del af Østersøen, det vil sige Horsens Fjord, Gudsø Vig, Lillebælt og Fehmern, og derfor også i nogen grad har en regional udbredelse.

Med hensyn til type D harpunen kendes den endnu kun i ganske få og meget spredte eksemplarer, hvoraf de fleste stammer fra Nordtyskland og omkring den vestlige Østersø (S.H. Andersen 1983; Schwabedissen 1995, Taf. 3,4; Taf. 7,3 og Taf. 15,4) (fig. 24).

Tilsammen svarer harpunernes geografiske forekomst meget nøje til Ertebøllekulturens største udbredelsesområde (fig. 23-24).

Det er vanskeligt at afgøre, om den geografiske udbredelse af type Aog B-harpunerne, der i hovedtrækkene dækker adskilte områder, men også viser en delvis overlapning, afspejler sociale/kulturelle forhold, som 
det har været fremført (Petersen 1984, s. 7-18), eller der evt. skjuler sig tids- eller funktionsforskelle i materialet. De to harpunformer kunne f.eks. enten tænkes at afspejle en gradvis formændring igennem et længere tidsforløb, eller typerne kunne have været anvendt til forskellige byttedyr. Jeg er mest tilbøjelig til at hælde til den sidste opfattelse. Den krumme udformning af type B-harpunerne er så særpræget, at der næppe kan være tvivl om, at den må være betinget af funktionen. Den østlige udbredelse af type B-harpunen kunne derfor tyde på, at den især har været anvendt til jagt på havpattedyr/sælarter, der har været særlig udbredt $\mathrm{i}$ denne del af landet, og som har haft sæsonvise træk igennem sunde og bælter. Her er grønlandssælen et oplagt bud på en art, der opfylder disse betingelser, og denne forklaring støttes også af den forholdsvis store mængde knogler af grønlandssæl, der er fundet på Ertebøllebopladsen Ølby Lyng, som netop ligger ved Køge Bugt (Møhl 1971b, s. 58-60).

Ser vi på harpunernes geografiske udbredelse i detaljer, er det interessant at konstatere, at der gradvist begynder at udskille sig lokalområder, hvor fundene "klumper" sig. Det gælder især egnen omkring Lillebælt og i Østjylland, f.eks. Gamborg Fjord (2 stk.), Kolding Fjord (4 stk.) og Gudsø Vig (5 stk.); længere nordpå er der også mange harpuner i Horsens Fjord (11 stk.), mens der efter de reviderede dateringer i dag kun kendes en Ertebølleharpun fra Limfjorden (fig. 23-24).

At det netop er i de samme områder, hvor Ertebøllebopladsernes affaldslag indeholder flest knogler af marine pattedyr - først og fremmest sæler og mindre hvalarter, men også en del knogler af storhvaler - er næppe tilfældigt, men afspejler givet det samme forhold, at jagt på havpattedyr har spillet en særlig vigtig rolle i disse områder. Her skal blot gøres opmærksom på den gamle tradition for fangst af marsvin i Lillebælt $\mathrm{i}$ forbindelse med deres efterårs- og vintertræk - en aktivitet, der har fundet sted helt op til vor tid (Petersen 1969; Møhl 1971a, s. 317-318). Både Gamborg Fjord og Gudsø Vig er snævre, aflukkede farvande, der kun har forbindelse med Lillebælt. Områdernes topografi har derfor gjort dem særlig egnede til jagt på havdyr (marsvin) under deres sæsonvise træk igennem farvandene. Set ud fra denne synsvinkel kan det derfor ikke overraske, at der både findes store Ertebøllebopladser med knogler af sæl, samt små- og storhval og mange harpunfund i disse områder.

Sluttelig er det vigtigt at understrege, at harpunerne overvejende, men ikke udelukkende, er fundet langs kysterne og ude i havet. Spredte fund af A, B og C-harpuner er imidlertid også fremkommet ved åløb eller forhistoriske indsøer (Åmosen, Tudeå, Salpetermosen (19) og Travedalen). Det viser, at harpunerne ikke udelukkende blev anvendt til havjagt, men i hvert fald også lejlighedsvis blev brugt til fangst ved søer og åer inde i landet; det fremgår i øvrigt også af harpunen fra Åmosen. De skader, der ses på denne, viser, at det ikke er et redskab, der tilfældigt er tabt i søen, 


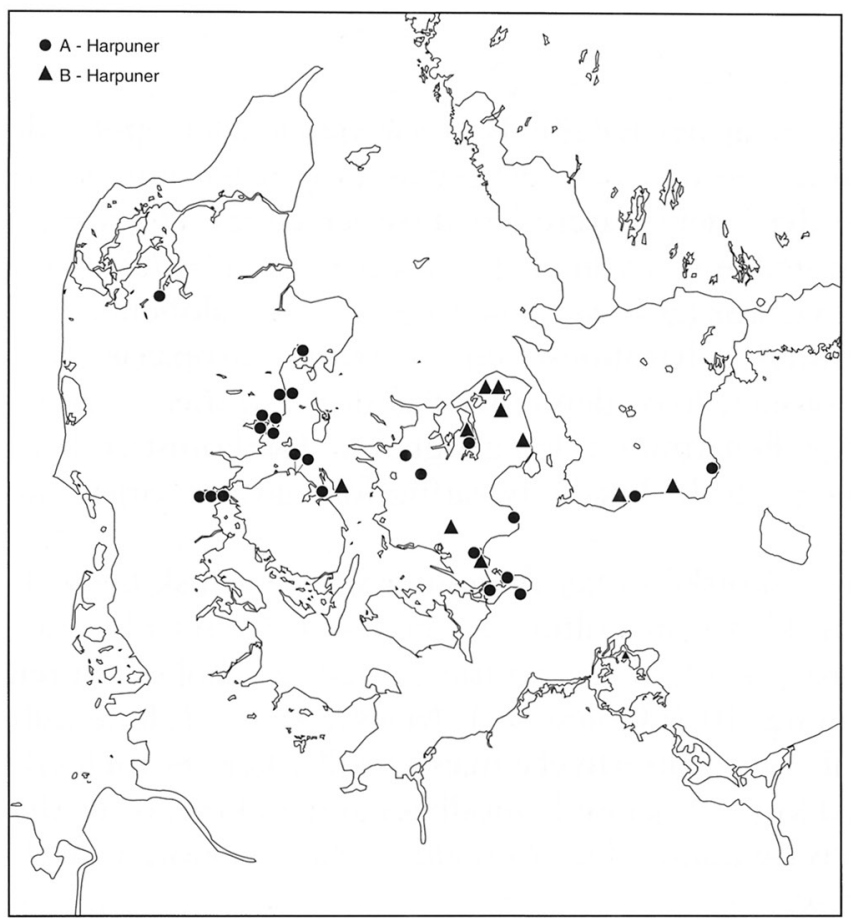

Fig. 23. Udbredelseskort over harpuntyperne A og B. Tegning: S. Kaae.

Distribution map for harpoon types $\mathrm{A}$ and $\mathrm{B}$.

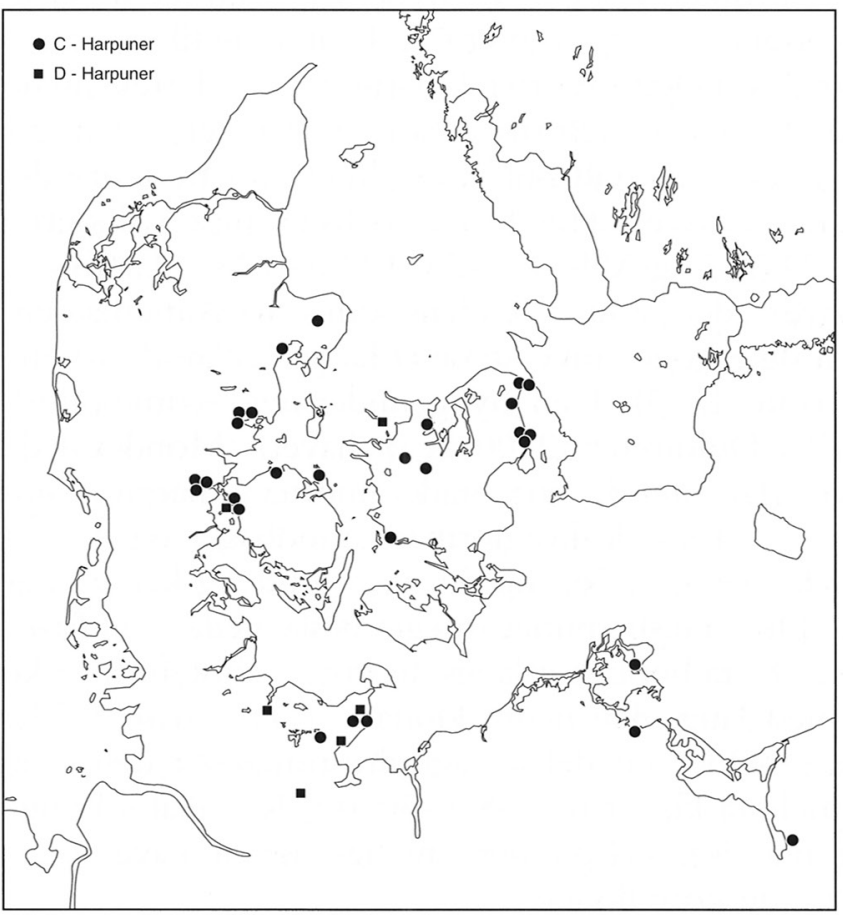

Fig. 24. Udbredelseskort over harpuntyperne $\mathrm{C}$ og D. Tegning: S. Kaae.

Distribution map for harpoon types $\mathrm{C}$ and $\mathrm{D}$. 
men derimod at den enten er mistet under jagt eller er blevet kasseret som følge af skader.

Det kan ikke udelukkes, at der lejlighedsvis har været sæler oppe i de havnære mundingsområder af de større danske åer, og at harpunerne er spor efter jagt på disse dyr, men snarere har disse våben været brugt til fangst af store fisk, som gedde (Esox lucius L.), laks (Salmo salar L.), malle (Silurus glanis L.) eller evt. stør (Acipenser sturio L.) i søer og åløbene.

Ser man på forekomsten af harpuner i en lidt større europæisk sammenhæng, er der flere steder, hvor denne redskabsform optræder samtidig med de danske Ertebølleharpuner; den geografiske forekomst er dog i meget høj grad betinget af de lokale bevaringsforhold for organiske materialer.

Langs de vest- nordvestskotske kyster findes der senmesolitisk kystkultur med skaldynger, såkaldt Oban-kultur, der er C-14 dateret til perioden ca. 3800-3100 f.Kr.(ukal.), d.v.s. samtidig med Ertebøllekulturen (Mellars 1987, s. 142 og fig. 10,1; Coles 1971; Mackie 1972). I dette miljø, hvor sæljagt har spillet en stor erhvervsmæssig rolle, kendes toradede hjortetaksharpuner med korte trekantede modhager og en kort, oval eller dråbeformet basis, i hvis midtakse, der er en aflang slids til snøren (Mellars 1987, s. 119, fig. 8,3).

I Central- og Sydøsteuropa - først og fremmest i Alpeegnene og langs de store floder - kendes der adskillige fund af harpuner. Særlig vigtige er resultaterne fra Birsmatten-hulen i Schweitz, hvor der i den næstøverste og øverste horisont (horisont 1 og 2), som er C-14 daterede til ca. 3500$3200 \mathrm{f}$. Kr. findes korte, toradede hjortetaksharpuner med trekantede modhager og kort, rund eller skjoldformet basis, hvori der - i nogle tilfælde, men ikke alle - ses et centralt hul til fanglinen; i dette indlandsmiljø menes harpunerne at have været brugt til fiskefangst $\mathrm{i}$ floderne (Bandi 1963, s. 23 og 224-227 og Abb. 15, 125, 128 og 128a). Lagfølgen i Birsmatten-hulen afspejler den samme tendens som i Sydskandinavien, d. v. s. en fremkomst af og en øget anvendelse af harpuner mod slutningen af Atlantisk tid (Bandi 1963). I en nylig undersøgt, senmesolitisk mandsgrav i de italienske Dolomiter (2100 m o. havet) (Mondeval de Sora) var der medgivet den afdøde en toradet hjortetaksharpun som gravgods. Den har korte, trekantede-krogformede modhager og skjoldformet basis (Alciari m.fl.. 1994, s. 362 og fig. 6,2). Endelig kendes der ganske mange toradede hjortetaksharpuner (meget beslægtede med Ertebølleharpunerne af type D) fra bopladser langs de store sydøsteuropæiske floder - først og fremmest langs den nedre Donau - (Tringham 1971). Harpunerne er i disse områder en del af jagtudrustningen i den sene Maritsa, Boian og Gumelnita kultur (ca. 3800-3000 f. Kr. ukal.)(Tringham 1971, s. 159 og fig. 26). Harpunerne menes her at have været anvendt til fangst af stør $i$ de store floder. 
For de skotske og mellemeuropæiske harpuner gælder, at de alle er toradede og har en kort, rund-oval basis. Heroverfor står de nordiske Ertebølleharpuner, der er meget større og som har en lang, tungeformet basis med rundt linehul; endvidere er Ertebølleharpunerne overvejende enradede.

\section{Kronologi}

Til trods for de mange nye fund er gruppen af harpuner stadig lille og for mange funds vedkommende også med mangelfulde fundoplysninger, der kun i få tilfælde giver mulighed for en mere præcis datering - både relativt og absolut. At nogle af de forskellige harpuntyper (og varianter) meget vel kan tænkes at afspejle en kronologisk udvikling, er en mulighed, der på det nuværende grundlag hverken kan bekræftes eller afvises, men indtil videre kan der kun skitseres en typeudvikling blandt de ældste harpunformer, se side 60 og 66; ellers er der ikke noget, der tyder i en sådan retning.

Der kendes stadig ingen sikre fund af harpuner eller affaldsprodukter fra ældre Kongemosekulturs kystbopladser; det kan skyldes et meget lille antal fundsteder, men kan også afspejle et reelt forhold, hvilket tilsyneladende er tilfældet. Da der imidlertid optræder knogler af både sæl og småhval på den tids bopladser (Mathiassen 1946, s. 32, Kapel 1969, s. 94; Larsson 1982), er disse dyr næppe blevet nedlagt ved hjælp af harpuner; her må andre fangstvåben og -metoder have været i brug.

De hidtil ældste, daterede harpuner dukker op i yngste Kongemose / ældste Ertebøllekultur (Skateholm II, Tudeå og evt. Klintholm), men er indtil videre meget fătallige.

Fra ældre Ertebøllekultur er der derimod mange og meget store bopladsfund fra hele landet, f.eks. Norslund, Lystrup, Dyrholmen 1, Maglemosegårds Vænge, Bloksbjerg m.fl. med et rigt og alsidigt redskabsinventar af organiske råmaterialer foruden knogler af mindre hvaler og sæler (Lystrup Enge: S.H. Andersen 1996, s. 10; Norslund lag 3-4: Møhl 1965, s. 107-109; Bloksbjerg: Westerby 1927, s. 33 og 35).

Fra disse bopladser kendes der også kun ganske fă harpuner (Lystrup og Bloksbjerg) - begge af C-type. Med undtagelse af C-harpunen fra Bloksbjerg (ældre Ertebøllekultur) (Westerby 1927, s. 105-106, fig. 33) har alle de tidligere publicerede C-harpuner enten været løsfund eller uden sikre fundoplysninger. Den nye Lystrup-harpun er derfor vigtig, da den stammer fra et C-14 dateret kulturlag på en kystboplads med oldsager fra en kortvarig fase af æeldre Ertebøllekultur 5250-4940 (kal.) (K-40524055 og K-5730) (S.H. Andersen 1996, s. 16). De to fund viser altså, at denne harpunform dukker op i ældre Ertebøllekultur. Dateringen støttes også af to publicerede fragmenter af C-harpuner fra Ertebøllebopladsen Bergmansdal nær Helsingør (Petersen og Petersen 1978, s. 11 og 16; fig. 
5,3-4). En af disse harpuner er særlig interessant, da den har et linehul i basis - omtrent ud for de udsparede knopper til linefæste. At dette funktionelle træk, som ellers kun kendes fra A- og B-harpunerne, nu også er konstateret ved en type C-harpun er med til at underbygge tolkningen af denne gruppe som "egentlige" harpuner. Bopladsen Bergmansdal tilhører ældre Ertebøllekultur, hvilket bl.a. er dokumenteret af en C-14 datering til 5570-5380 f.Kr. (kal.) ( \pm een standardafvigelse og med hensyntagen til en reservoireffekt på ca. 300 år) (K-4272).

Også B-typen kendes i et eksemplar fra Skateholm I, hvilket er med til også at datere denne type til ældre Ertebøllekultur (Larsson 1986,1988). A-harpunerne er derimod endnu ikke med sikkerhed dateret til ældre Ertebølletid. Hertil skal føjes - hvad der er mindst lige så vigtigt -, at der på de ovennævnte bopladser ikke er fundet affaldsprodukter fra harpunfremstilling, det vil sige kronhjortegevir med spor efter udspaltning af "hjortetakstrimler", en oldsagsform, der ellers er så almindelig og karakteristisk på den sene Ertebøllekulturs kystbopladser (S.H. Andersen 1972, s. 105-107).

Dette tyder unægtelig på, at harpunen også har været en sjælden våbentype i den ældre Ertebøllekulturs redskabsforråd, selvom der også i denne situation må tages et forbehold for fundstoffets repræsentativitet.

Fra mellemste og især yngre Ertebøllekultur foreligger et større antal sikkert daterede harpuner af A-, B- og C-type fra adskillige bopladsfund, f. eks. Flynderhage, Vejlebro, Bloksbjerg, Agernæs, Ronæs Skov, Skateholm og Grube-Rosenhof.

I denne henseende er forekomsten af en C-harpun i kulturlaget ved

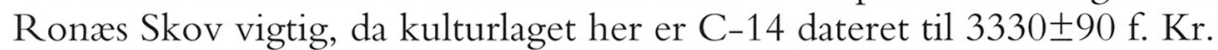
(ukal.) (K-5731), hvilket vil sige yngre Ertebøllekultur. Dette svarer fint til resultaterne fra Grube-Rosenhof, hvor en af C-harpunerne med sikkerhed er dateret til fundhorisonten fra yngste Ertebølle (de øvrige er uden sikre fundoplysninger og kan derfor kun dateres til Ertebøllekulturen i bredeste forstand).

Med hensyn til D-typen kan den på grundlag af bopladsfundet fra Agernæs (side 55-56) dateres til yngre Ertebøllekultur. Derimod kan harpunfragmentet fra Grube-Rosenhof (Schwabedissen 1995, Taf. 15,4) ikke dateres nærmere inden for Ertebøllekulturen, men sandsynligheden peger dog mest på den yngre del af perioden

Hovedparten af de danske Ertebølleharpuner af type A, B, C og D skal dateres til mellemste og - især - yngre Ertebøllekultur. Set under et større tidsforløb er det vigtigt at bemærke, at antallet af harpuner forøges markant i den sene Ertebølletid - både med hensyn til hovedformer og varianter.

Konklusionen er, at der åbenbart sker en differentiering og specialisering af redskabsinventaret til fangst af marine pattedyr i sen Ertebøllekul- 
tur - hvilket må betyde, at havjagten på dette tidspunkt har fået en anden (og større) betydning end tidligere. Om dette også kan eftervises i en tilsvarende stigende hyppighed af sæl- og hvalknogler på bopladserne, har det endnu ikke været muligt at efterforske.

De nye fund forøger antallet af harpuner så meget, at vi nu med større styrke end tidligere kan fastslå, at harpunen har været et almindeligt og vigtigt fangstvåben i sen Ertebøllekultur, og at den stigende hyppighed i anvendelsen af et så specialiseret redskab tilsvarende må afspejle en forøget vægt på de marine ressourcer, sæl og hval.

Er det enten et resultat af nye jagtformer, en mere intensiv havjagt, eller er det en følge af nye og evt. større forekomster af sæl- og hvalarter end tidligere?

\section{Funktion og byttedyr}

Harpunen er et vigtigt og specialiseret fangstredskab, der har været uundværligt ved jagt på havpattedyr. At harpunerne især har været anvendt ved fangst på sæl (og evt. også hvaler) er sandsynligt - især på steder og årstider, hvor disse dyr levede spredt og derfor var vanskelige at nedlægge. Den ensartede størrelse af type A-, B- og C-harpunerne kan tages som tegn på, at de har været anvendt til den samme gruppe af havpattedyr (sæler). Kun længden af type D afviger så markant fra de andre typer, at den kunne tænkes at have haft en væsentlig anden funktion, f.eks. havjagt på større havpattedyr - hvaler ? Fundet af denne harpun på dybt vand ud for Føns-halvøen (S.H. Andersen 1982, s. 7, note 1), viser med sikkerhed, at D-harpunerne blev brugt på åbent vand og langt til havs (fig. 25). Tilstedeværelsen af fire forskellige hovedtyper viser imidlertid også, at de må have været udformet med henblik på forskellige byttedyr og fangstsituationer.

Faunalevnene fra de danske Ertebøllebopladser viser, at der i denne periode især blev drevet jagt på gråsæl (Halichoerus grypus), men også grønlandssæl (Phoca groenlandica) optræder jævnligt; hertil kommer desuden ringsæl (Phoca foetida) og spættet sæl (Phoca vitulina), men i mindre antal. Yderligere findes der jæevnligt knogler af marsvin (Phocaena phocaena (L.) og de lidt større hvaler såsom spækhugger (Orca gladiator) og øresvin (Tursiops trunchatus) (Møhl 1971a).

Hyppigst er gråsæl (Halichoerus grypus), der er tilstede på de fleste danske og skånske Ertebøllebopladser, og som må have været langt den vigtigste erhvervsmæssige ressource blandt de danske farvandes sæler og småhvaler (Møhl 1971a; Larsson 1988, s. 67). Rester af sæler findes især på bopladserne ud til Kattegat, Øresund og Limfjorden,-- farvande, hvor også de historisk kendte ynglesteder ligger - eller har ligget.

Gråsælen er særlig almindelig på Ertebølle (locus classicus) (mindst syv individer) (Madsen m.fl. 1900, s. 86), og forekommer også som et frem- 

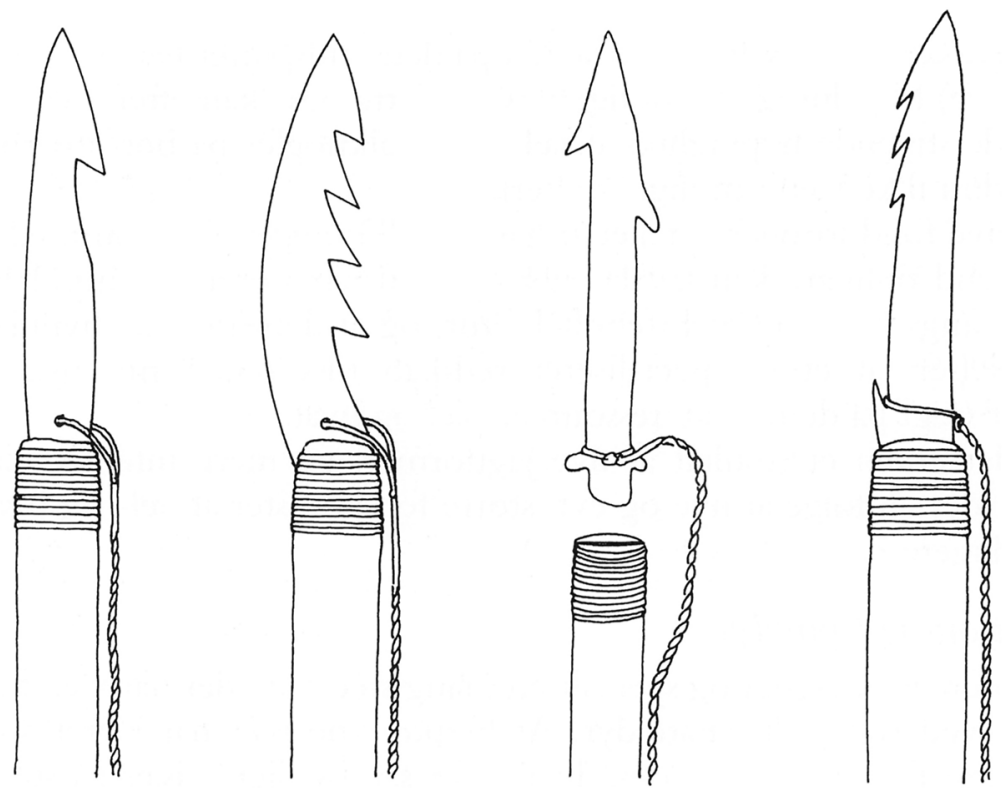

Fig. 25. Forslag til skæftning af Ertebøllekulturens harpuner.

Suggestion for hafting of the four main harpoon types of the Ertebølle culture.

trædende faunaelement på Sølager (Skaarup 1973, s. 77 (lag 1), Klintesø (Madsen m.fl. 1900, s. 131), Langø (hvor det fortrinsvis er unge dyr, der er repræsenteret i materialet) (Broholm 1928, s. 179) og Havnø (især knogler fra hovedet) (Madsen m.fl. 1900, s. 111).

Den regelmæssige og jævnlige forekomst på næsten alle kystbopladser tyder på, at sæler har været en vigtig ressource. Dyret giver både et velsmagende kød og værdifuldt spæk samt gode skind. Et yderligere argument for betydningen af jagt på havpattedyr er forekomsten af et specialvåben som harpunen og de karakteristiske Ertebølle "spæklamper" (selvom det ikke kan udelukkes, at der også kan have været anvendt planteolie i lamperne). I den forbindelse er det interessant at konstatere, at "lamperne" først dukker op i den yngre Ertebøllekultur - altså samtidig med at harpunerne bliver særligt hyppige.

Et andet - og mindst lige så vægtigt argument for betydningen af den marine fangst - er, at harpunen medgives som gravgods (grav IV på Skateholm II). Dette fund understreger den vigtighed, harpunen har været tillagt som jagtvåben i ældre Ertebøllekultur og trækker samtidig tydelige analogier til de langt yngre grave fra grubekeramisk kultur på f. eks. Västerbjers på Gotland, hvor harpuner hyppigt indgår som gravgods, og hvor fangst af sæl har været et meget væsentligt aspekt i erhvervet (Steenberger 1939; Janzon 1974, s. 59-61 og Pl. 8, 11, 15, 16, 28, 48 og 51). 
Sælknoglerne stammer fra alle skelettets dele, hvilket må betyde, at disse dyr jævnligt, men ikke nødvendigvis altid, blev hjembragt i hel tilstand til bopladserne. Talmæssigt er knogler af sæl imidlertid forholdsvis sparsomt forekommende på Ertebøllebopladserne. Det afspejler næppe disse dyrs virkelige betydning for de datidige fangstsamfund, men er nok snarere enten en følge af de forskellige nedbrydende/ødelæggende forhold, der har påvirket faunaresterne fra stenalderen til i dag, såsom at knoglerne kan være blevet ædt af hunde (fig. 32), eller de fedtholdige knogler kan have været anvendt som brændsel - for blot at nævne nogle enkelte forhold, som kan have påvirket sælknoglernes tilstedeværelse på bopladserne.

Endelig må det ikke glemmes, at denne fangst både var stærkt sæsonpræget, intensiv i en kort periode og samtidig foregik fjernt fra bopladserne, på øer, rønner, rev og grunde m.m., hvor der normalt er meget dårlige bevaringsforhold for organiske levn, og som samtidig er lokaliteter, der på grund af topografiske og geologiske forhold altid har været særligt udsatte for senere at blive skyllet bort af havet - evt. en kombination af disse forhold (Paludan-Müller 1978, s. 129-131). På sådanne steder kan man enten have spist kød og spæk, eller disse råvarer er blevet hengemt $\mathrm{i}$ gruber eller tørret for så senere at blive bragt til bopladserne. Aktiviteter, der vil være meget vanskelig at efterspore rent arkæologisk. Hertil kommer, at fangsten af marine pattedyr ikke udelukkende har været et spørgsmål om kød og skind, som man ellers kunne være tilbøjelig til at tro ud fra bopladsernes knoglemængder, men kan også have haft en anden og lige så stor eller større betydning, fordi den har været en vigtig anledning til social kontakt mellem fangergrupperne (se side 85).

Basispartiets ensartede udformning og størrelse på harpuner af type $\mathrm{A}$, $\mathrm{B}$ og D tyder afgjort på, at de må have været skæftet på samme måde, det vil sige, at de har været sat direkte ind i et skaft, der i den ene ende har haft en aflang, udskåret hulning, som så har omsluttet harpunernes basis. De jævnlige fund af afbrækkede basisstykker på bopladserne fra f.eks. Bjørnsholm, Langø, Gudsø Vig, Bergmansdal, Skateholm IX og Rosenhof, må skyldes, at basisdelens svageste sted har været ved hullet til snøren. Det er derfor, at det er her, de er brækkede, men antagelig også fordi den nederst del af basis har været solidt beskyttet i skaftets hulning.

Her kan yderligere nævnes to - ikke tidligere publicerede - brudstykker af hjortetaksharpuner, der begge er brækkede lige under modhagerne. Brudstykkerne er vanskelige at typebestemme, men den ene er sandsynligvis en type A-harpun og den anden en B-harpun (fig. 26,1-2). De er begge med rundede kanter, halvcirkulært tværsnit, og i profil er harpunerne lidt buede. Harpunen, fig. 26,1, har symmetrisk spidsovalt omrids, mens fig 26,2 er lige omkring basis, men krummer opefter. Begge har tungeformet basisafslutning, der er glatskrabet og hvori der ses et 
hul til snøren, ca. $6 \mathrm{~cm}$ fra basisafslutning. Linehullet på harpunen, fig. 26,1, er lidt usymmetrisk placeret og er samtidig ovalt og går skråt igennem basis (diam. er ca. $1 \mathrm{~cm}$ ), mens hullet på harpunen,fig. 26,2, sidder i midtaksen og er ca. $0,8 \mathrm{~cm}$ i diameter. Denne harpun er med glatskrabet overflade, og er blankslidt på basispartiets kanter og bredside - antagelig fordi den har siddet lidt løst i skaftet. Denne harpun viser en interessant detalje, da der (på undersiden i takkens bløde væv) er indskåret en langsgående fure fra linehullet og ned til basis afslutning; i denne fure har fanglinen formodentlig været anbragt således at den ikke har generet harpunens placering i skaftet. Begge harpuner mangler spidsen og modhage(-r), som er brækket af som følge af en kraftig belastning, der ikke blot har brækket spidsen, men også har flækket en splint af forsiden. Der er her tale om en meget voldsom "skudskade" - hvilket svarer til skaden på harpunen (fig. 4). Længden af harpunen, fig. 26,2, er $18 \mathrm{~cm}$, bredden er 3,4 cm og tykkelsen er $1,9 \mathrm{~cm}$. Den anden, fig. 26,1 , er $14,8 \mathrm{~cm}$, bredden er 2,9 cm og tykkelsen er 1,2 cm. De er ved forskellige lejligheder fundet på submarine skalbanker nær Selsø Sø ved Roskilde Fjord (14).

Hvilken fangstmetode, der har været benyttet ved Ertebølletidens sæljagt, må have været betinget af arten. Gråxæl nedlægges nemmest på
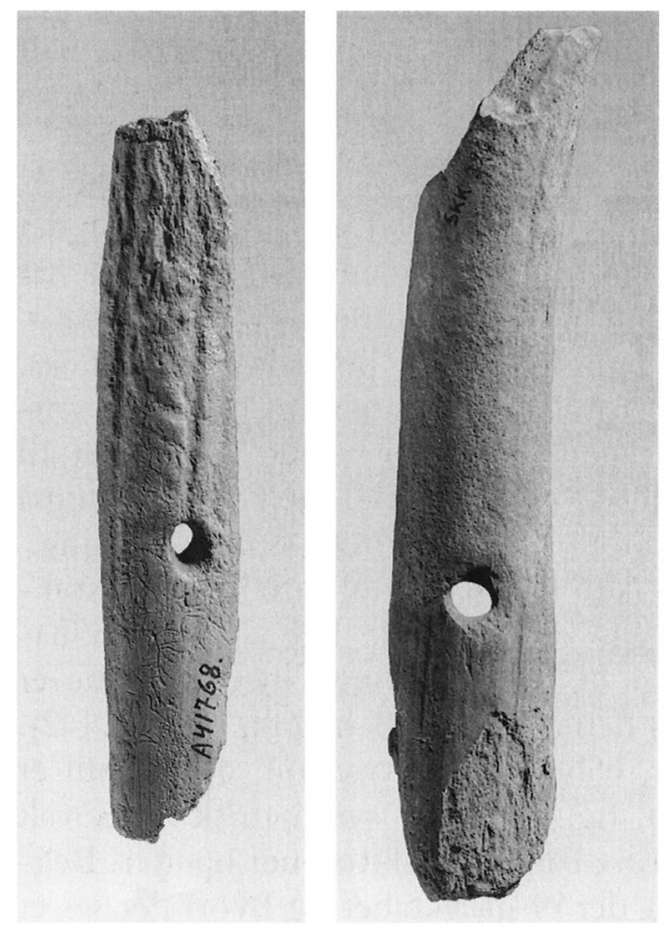

Fig. 26. Hjortetaksharpuner hvor den forreste del er brækket af. Fra undersøisk skalbanke i Selsø Sø, Roskilde Fjord. Foto: P. Dehlholm. 1:2.

Antler harpoons in which the first part is broken off. From a submarine shell bank in Selsø Sø, Roskilde Fjord. 
ynglepladserne, hvor den træffes i stort tal om vinteren. Her fortæller mange historiske kilder, at der ved sådanne lejligheder oftest blev benyttet køller eller net. Harpunerne er derfor i højere grad blevet anvendt til de andre sælarter samt til jagt på gråsæler ude på havet i forårs-, sommerog efterårsperioden, hvor de lever spredt i farvandene og derfor ofte må jages til søs og enkeltvis (Møhl 1971a, s. 309; Clark 1989, s. 66-78). Dette stemmer fint med de konklusioner, som Clark nåede frem til ved undersøgelser af fundene i Østersøen, hvor stenalderharpunerne især blev brugt til jagt på grønlandssæl og ringsæl, mens gråsæl og spættet sæl blev jaget på anden vis (Clark 1976, s. 120-121).

I denne sammenhæng skal de nyere C-13 analyser af menneskeknogler fra Ertebøllebopladserne også nævnes (Tauber 1981). Disse undersøgelser viser samlet, at i hvert fald den kystboende Ertebøllebefolkning i overvejende grad levede af havets fødekilder, og at mængden heraf $i$ grove træk har svaret til, hvad der kendes fra Østgrønland (Tauber 1981, s. 122126). Sporene af marin føde i Ertebøllebefolkningens knogler har i den danske, arkæologiske litteratur næsten udelukkende været forklaret som et resultat af et stort fiskeri, og man er ligefrem gået så vidt som til at foreslå, at ældre stenalders slutning skulle benævnes "fiskestenalderen" (Tauber 1981, s. 122). At fiskeriet virkelig har været omfattende, er dokumenteret, men omfanget (og betydningen) af de marine havpattedyrs andel af den marine fødekomponent er efter min mening blevet undervurderet - en opfattelse, der også er blevet fremsat fra anden side (Aaris-Sørensen 1988, s. 199).

Det er også tankevækkende at erindre sig de beregninger, som er foretaget af indholdet $\mathrm{i}$ en $50 \mathrm{~m}^{3}$ stor stikprøve fra Meilgaard køkkenmøddingen (Bailey 1978). Den indeholdt kun ganske få knogler af sæl, men udregnes næringsværdien af de vigtigste ressourcer (køddyr, fugle, fisk og muslinger), ses, at de få sæler udgør en ganske stor del (31,9\%) af næringsværdien (Bailey 1978, Tavle 2, s. 47 og 49). Sådanne beregninger giver altså et helt andet indtryk af disse byttedyrs betydning, end man umiddelbart får af de sparsomme knogler. Det skal dog også understreges, at der ikke kendes bopladser, der leder tanken hen på en "sælfangerkultur" i lighed med de arktiske (Møhl 1971a, s. 324). Sæljagten har dog afgjort været væsentlig for Ertebøllebefolkningen, men har dog ikke været afgørende for placeringen af hovedparten af de store, "centrale" kystbopladser.

I stedet for at koncentrere sig om de forholdsvis fătallige knoglefund, er det $\mathrm{i}$ virkeligheden nok langt vigtigere at bemærke den konstante forekomst af disse dyr og konstatere, at sælen er en karakteristisk del af faunaen på næsten alle Ertebøllekystbopladser med bevarede dyreknogler selv på meget små lokaliteter og på steder med dårlige bevaringsforhold for organiske levn. 
Alle disse forskellige indfaldsvinkler peger samstemmende på, at jagten på de marine pattedyr har været af stor betydning i Ertebølletid, og at betydningen givet også har været større end hidtil antaget.

Betydningen af den marine havjagt fremgår også af, at knogler af disse dyr ikke kun findes på kystbopladserne, men også i nogle tilfælde forekommer på indlandsbopladser som f.eks. Ringkloster (S.H. Andersen 1975, s. 88). Udvekslingen af spæk m.m. fra fangstlokaliteterne har altså ikke blot været begrænset til kystbopladserne, men har også omfattet indlandets bopladser, hvor "lamperne" er en jævnligt forekommende type.

Endelig skal det også tilføjes, at alle de overvejelser, der er fremsat i forbindelse med sælfangsten højest sandsynligt også er dækkende for de mindre hvalarter som marsvin (Phocaena phocaena), spækhugger (Orca gladiator), øresvin (Tursiops trunchatus), hvidnæse (Lagenorhynchus albirostris) og hvidhval (Delphinopterus leucas), der både kendes på Ertebøllebopladserne og som skeletfund i havaflejringer fra atlantisk tid (Møhl 1971a, s. 316-317; 1971b, s. 60; Aaris-Sørensen 1988, s. 187-188).

At systematisk jagt på hvidnæse ikke kun har været praktiseret i Ertebølletid, men har ældgamle traditioner i Norden og kan følges helt tilbage til den tidlige del af ældre stenalder, viser de nye fund fra kystbopladsen Huseby Klev i den bohuslenske skærgård. Her blev der flere steder i affaldslaget ud for bopladsen fundet sammenhørende dele af rygrader fra adskillige individer af denne hvalart (Hernek og Nordquist 1995, s. 87-98).

Især marsvinet er almindeligt forekommende i danske fund fra atlantisk tid, og der kendes mindst 40 fund (Møhl 1971a; Aaris-Sørensen 1988, s. 188). Denne hvalart forekommer så jævnligt på Ertebølletidens kystbopladser, at befolkningen sandsynligvis har drevet den samme type organiseret drivjagt på disse dyr, som er blevet praktiseret helt op til vore dage, hvor de jages om vinteren (perioden november-februar) (Petersen 1969; Berglund 1979). Fra Ertebølletid kan der peges på et interessant fund fra bopladsen Møllegabet ved Ærø, hvor der bl. a. er fremkommet en sammenhørende rygrad af marsvin (fig. 27) (Skaarup 1980, s. 5), samt bopladsen Ølby Lyng ved Øresund, hvor marsvin er et karakteristisk og vigtigt indslag i den marine fauna (Møhl 1971b, s. 60). At der endnu ikke er fundet Ertebøllebopladser, hvor marsvin er et dominerende element i erhvervet, kan skyldes, at de bopladser, som lå ved de særlig gode fangststeder - især ved Lillebælt - i dag ligger under vand som følge af sænkningen af denne del af landet siden stenalderen.

Med hensyn til jagtformen giver de danske stenalderfund ingen sikre spor. Harpuner kan have været anvendt, men fangst med net er også en mulighed. I Japan, hvor der i den tidlige Jomonfase (ca. 4000-3000 f. Kr.) blev drevet en meget omfattende jagt på mindre hvalarter, er en kombination af drivjagt fra båd og med forskellige typer af net den almindeligste fangstmetode; brug af bue og pil er imidlertid også kendt 


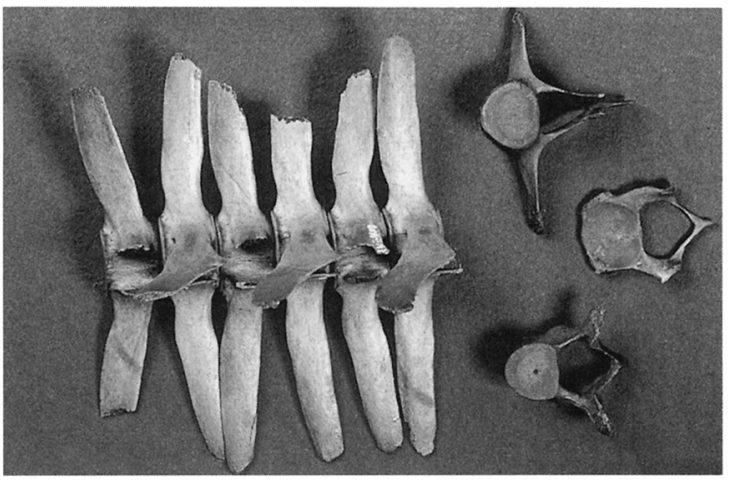

Fig. 27. Rygrad af marsvin fra submarin Ertebølleboplads, Møllegabet I ved Ærø.

Foto: Langelands Museum.

Spinal column of porpoise from a submarine Ertebølle settlement, Møllegabet I near Ærø.

(Hiraguchi 1992, s. 38-39; 1993, s. 49;1995, s. 65). Fra Danmark kendes også historiske beskrivelser af drivjagt med båd og net. En kollektiv jagtform baseret på organisation og perfekt samarbejde mellem jægerne, var nødvendig for et heldigt resultat. Dyrene blev drevet ind på grundt vand, hvor hvalflokkene blev indespærret ved hjælp af forskellige typer garn for derefter at blive nedlagt og parteret. At der var tale om betydelige byttemængder fremgår af de historiske kilder, som beretter, at den sæsonmæssige marsvinefangst i Lillebælt svingede mellem 500 og 2000 dyr, og at dagsfangsten lå på 15-40 dyr (Berglund 1979, s. 23).

Senmesolitiske både er velkendte fra Danmark (S.H. Andersen 1996), og at net også kan have været anvendt her i landet, antydes måske af tilstedeværelsen af forholdsvis tunge netsynk på flere Ertebøllebopladser på Djursland og Mols, f. eks. Kolind (Mathiassen 1948, s. 30 og nr. 116) og Vængesø (S.H. Andersen 1995, s. 57 og fig. 18 th.).

Den eneste våbenform til havjagt, der endnu mangler $\mathrm{i}$ det danske fundstof er "kastetræ" til at kaste harpunen. Et nyt fund fra Ertebøllebopladsen, Ronæs Skov (fig. 28) er antagelig et sådant "kastetræ", som hermed for forste gang er påvist på en Ertebølleboplads. Det er fremstillet af elmetræ (Ulmus sp.) (bestemt af C. Malmros) og er meget elegant formgivet med et ca. $65 \mathrm{~cm}$ langt håndtag, der afsluttes i et tungt, golfkøllelignende hoved.

Et af problemerne i forbindelse med at vurdere omfanget af den marine havjagt i Ertebølletid har været en tilsyneladende mangel på "specialiserede" kystbopladser, hvorfra denne erhvervsaktivitet har kunnet dokumenteres. Imidlertid er det rimeligt ud fra de geologiske og topografiske forhold i de danske farvande sammenholdt med de kvartærzoologiske fund at vente, at sådanne specialiserede "sælpladser" må have været tilstede $\mathrm{i}$ stort antal $\mathrm{i}$ atlantisk tid - især når man tager den rige marine fødekæde i betragtning. Sådanne fangstlokaliteter har imidlertid været kendt $\mathrm{i}$ mange år, men har ikke været tillagt særlig betydning $\mathrm{i}$ relation til Ertebøllekulturen. Her skal blot gøres opmærksom på vel- 

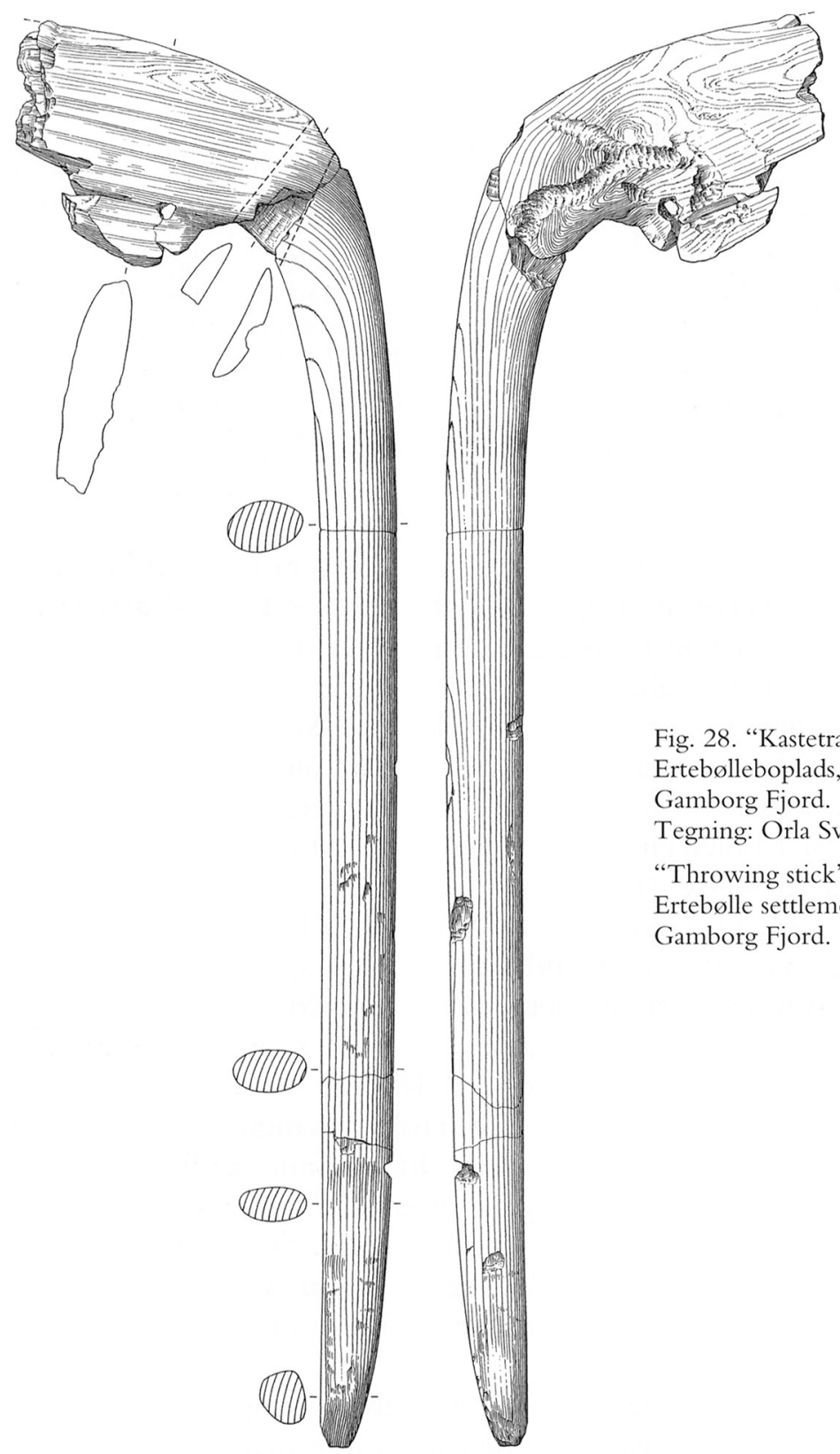

Fig. 28. "Kastetræ" fra undersøisk Ertebølleboplads, Ronæs Skov, i Gamborg Fjord.

Tegning: Orla Svendsen. 1:4.

"Throwing stick" from a submarine Ertebølle settlement, Ronæs Skov, in Gamborg Fjord.

kendte lokaliteter som f. eks. Selbjerg i Limfjorden (Marseen 1953, s.106-107; S.H. Andersen 1992, s. 78) og Hesselø, hvor hhv. kulturlag og typiske oldsager fra sen Ertebøllekultur viser, at disse steder ogsa blev anvendt i Ertebølletid (Skaarup 1973, s. 22-24 og fig. 1, nr. 2,3 og 5, fig. 2, nr. 2 og fig. 5, nr. 8); disse fund har der været en tilbøjelighed til at overse på grund af de massive og fundrige aflejringer fra yngre stenalder. Det er rimeligt at antage, at de ressourcer, der tiltrak fangerne i 
yngre stenalder, kan have været de samme, der var baggrunden for, at Ertebøllejægerne også besøgte disse steder.

Andre bopladser må også ud fra deres topografiske placering og faunalevn på tilsvarende måde tolkes som steder, der har været særlig rettet mod fangst af marine havpattedyr. Her tænkes på bopladser som Langø på Nordfyn, Ordrup Næs, Sejerø, Klintesø i Nordvestsjælland (Broholm 1928, s. 179; Becker 1939, s. 224; Liversage 1980, s. 88; Madsen m. fl. 1900, s. 131) og Hjortholm i Stavns Fjord på Samsø (Malmros 1995, s. 39). For alle disse lokaliteter gælder, at det er steder, der ligger på små øer eller holme uden et større tilgrænsende landområde/bagland (de kan benævnes som "ydre øer"), og samtidig er disse steder betydelig mere haveksponerede end hovedparten af Ertebøllekystbopladserne.

Nye fundsteder af denne type fortsætter heldigvis med at dukke op, $\mathrm{f}$. eks. i Limfjorden, hvor de først og fremmest er fundet på strandvoldene, bl. a. eksemplificeret ved den nylige udgravning af lokaliteten Rønbjerg Strandvolde (15).

De tidligere omtalte små øer med skaldynger fra Obankulturen ud for den vestskotske kyst er også fine eksempler på sådanne små haveksponerede "sælstationer", der har fungeret i nær kontakt med større, mere permanente kystbopladser på andre, men større, nærliggende øer og/eller det skotske fastland (Mellars 1987).

Indtil videre er der i Danmark kun udgravet en enkelt Ertebøllekystboplads, hvor knogler af sæl, hval og havfugle dominerer faunalevnene. Et sådant fundsted er en endnu upubliceret kystboplads ved Vængesø på Helgenæs - et område, hvorfra der tidligere er publiceret et andet lille Ertebøllefund med et tydeligt marint præg i faunaen (S.H. Andersen 1975) (16). På den nye boplads præges faunamaterialet af et stort indslag af fisk (torsk og fladfisk), søfugle (skarv, alk, lomvie, gejrfugl og ænder m.m.), sæler (gråsæl, spættet sæl, ringsæl og grønlandssæl), små hvaler (marsvin og delfin) foruden talrige splintrede knogler af store hvaler (ubest.) (17). At den marine fangst har været et af hovedmotiverne til at opholde sig på dette sted fremgår af, at stedet i ældre stenalder har været en isoleret og ganske lille $\varnothing$, som er indgået $\mathrm{i}$ et rev, der har været omskyllet af Kattegat på alle sider. Øen har hverken haft ferskvand eller en egen fauna af landdyr. Udover et redskabsinventar af typisk yngre Ertebølletype indeholder dette fund også den tidligere beskrevne harpun (side 50, fig. 5), et stykke tilhugget hvalknogle samt flere harpunforarbejder af både kronhjortetak og hvalknogle, end der kendes fra nogen anden jysk Ertebølleboplads (fig. 29).

Om harpunerne også har været brugt til jagt på storhval er stadig et åbent spørgsmål, men det er efter min mening overordentlig sandsynligt. Littorinahavets rige fødekæde må afgjort også have betydet flere hvaler af de større arter - og af flere forskellige arter - i de danske farvande, end i dag. 


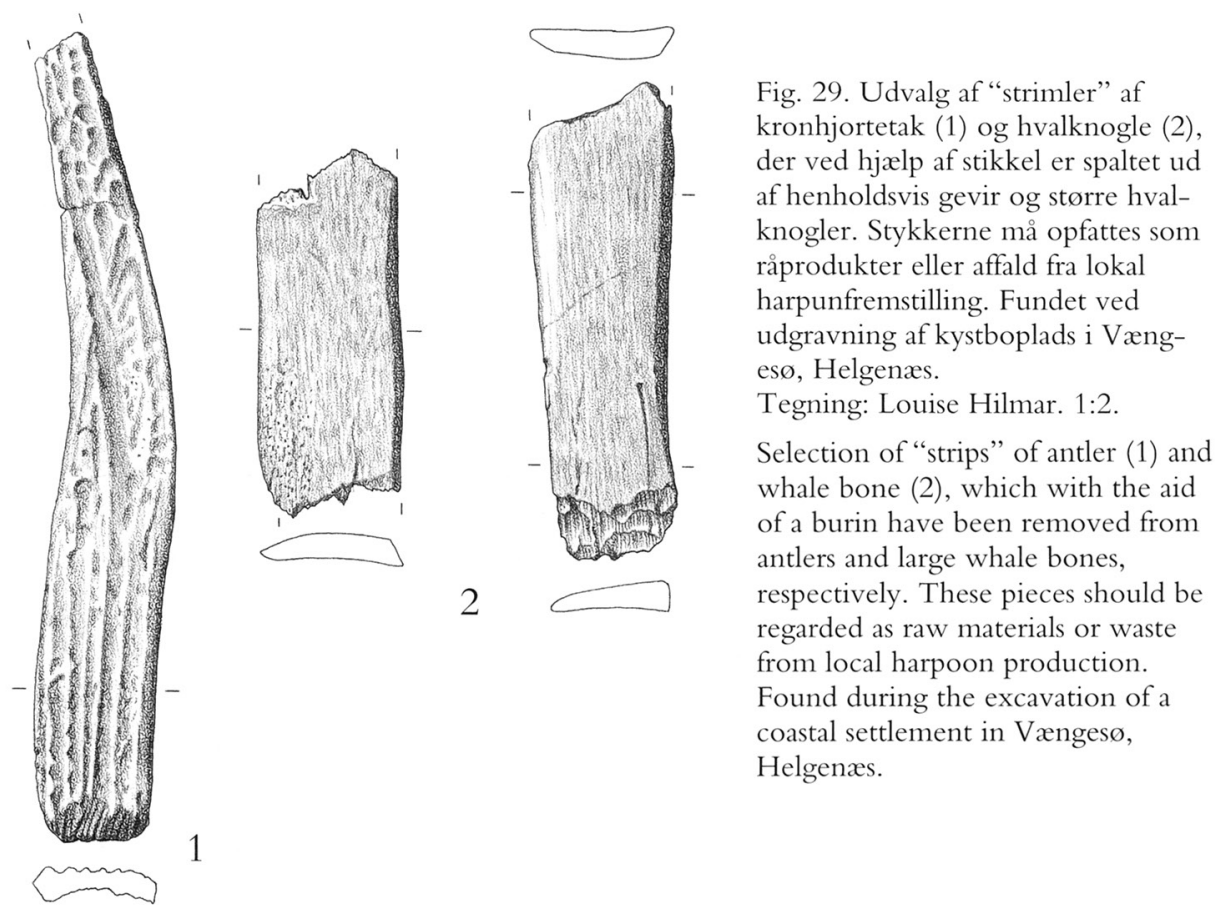

Knogler af sådanne hvalarter er jæunligt til stede på mange østjyske og vestfynske Ertebøllebopladser - ofte i form af ribben eller stykker af ribben, og samtidig er hvalknogle, som før nævnt, ofte blevet anvendt som råmateriale til harpuner (se fig. 5, 11, $12 \mathrm{og} \mathrm{27).} \mathrm{Dette} \mathrm{råstof} \mathrm{må} \mathrm{altså}$ have haft de samme materialeegenskaber som kronhjortetak, det vil altså sige, at det både er sejt og kan holde til store belastninger, før det brækker. At hvalknogle skulle have været anvendt som et alternativ til kronhjortetak - i situationer, hvor der har været mangel på dette råmateriale kan selvfølgelig ikke afvises, men er ikke sandsynligt. Langt snarere kan det tænkes, at der ligger et symbolsk element $i$ valget af dette råmateriale - muligvis for at understrege et rituelt forhold mellem byttedyr og fangstvåben.

At disse dyrs knogler virkelig har været i udstrakt brug som råmateriale til fangstredskaber fremgår ikke blot af de omtalte harpuner, men også af flere nye fund af bearbejdede hvalknogler på Ertebøllebopladserne. På et stykke hvalknogle fra Tybrind Vig ses mange og kraftige mærker efter grov tilhugning med økse; tilsvarende gælder et hvalribben fra Gamborg Fjord med spor efter overhugning - omtalt nedenfor (fig. 32), og endelig er der flere hvalknogler fra bopladserne omkring Vængesø, der ligeledes viser hugspor (fig. 31). Det kan derfor ikke udelukkes, at de jævnlige bopladsfund af hvalribben måske ikke blot repræsenterer jagtbytte, men derimod også kan have været opmagasineret råmateriale til harpunfremstilling. 
Hvalernes nytteevne er imidlertid ikke kun et spørgsmål om råmateriale til harpuner. Disse dyrs størrelse og dermed store indhold af kød, spæk (og olie), må have gjort dem til umådeligt vigtige byttedyr for den datidige kystbefolkning (Clark 1989, kap. 5, s. 87-109). Hertil kommer, at deres skind kan have været brugt til yderbeklædning på både, remme og til harpunliner; mavesækken kan forarbejdes til flydeblære til harpunjagten og til poser og sække; endelig er de fedtholdige knogler særdeles velegnede som brændsel (Friesen og Arnold 1995, s. 23). Udover hvalernes betydning som leverandører af mad og råmaterialer spiller hvaljagt også en meget stor social rolle for mange nulevende, nordlige kystsamfund, der driver - og har drevet hvaljagt. Det skyldes bl. a. at denne jagt kræver stor indsats af mange fangere og samtidig skal styres og koordineres i betydelig grad - ofte af en leder (Frisen og Arnold 1995, s. 23). Fra Danmark kan der peges på den tidligere omtalte organisation af marsvinejagten, der foregik under ledelse af en formand, som regulerede antallet af fangere, der atter var organiserede $i$ bådehold. Et andet vigtigt socialt aspekt var de meget præcist udfærdigede regler for fordelingen af fangsten efter jagten.

Hyppigheden af hvalknogler på Ertebøllebopladserne i Østjylland fremgår af, at der alene i Horsens Fjord kendes 11 kystbopladser, hvorpå der er fundet knogler af større hvalarter, og tilsvarende forhold gør sig gældende ved Norsminde Fjord og Brabrand Fjord, hvor der på de større Ertebøllebopladser er knogler af mellemstore og store hvalarter, hvilket, der ikke tidligere er blevet lagt særlig meget vægt på, og som er et erhvervsaspekt, som adskiller disse kystbopladser fra de samtidige lokaliteter i Limfjorden og i Østdanmark. Ud over de østjyske fjorde kan opmærksomheden også henledes på det førnævnte Vænge Sø-område, hvor der både er fundet skeletdele af en finhval (rørhval) (Balaenoptera physalus) samt knoglestykker af storhval på ikke mindre end tre af de omkringliggende Ertebøllebopladser (fig. 30) (S.H. Andersen 1975, s. 948; Hiraguchi 1995, s. 65-74). I et tilfælde viser en hvalknogle tydelige spor efter øksehug, og et andet knoglestykke er grovforarbejdet med øse, så det har făet lige kanter.

Også på bopladserne Tybrind Vig og Gamborg Fjord ved Lillebælt og Møllegabet I ved Ærø er der fundet flere knogler af større hvalarter. Fra Gamborg Fjord kendes et interessant fund (fig. 32). Det er et stykke af et hvalribben, der i den ene ende er omhyggeligt overhugget med en økse - antagelig for at anvende "nabostykket" til fremstilling af en harpun; denne tolkning styrkes af, at der er tale om et stykke knogle, som er tæa $\mathrm{i}$ benmassen og - set i profil - også er meget lige og derfor særlig velegnet til redskabsfremstilling. På indersiden ses et kegleformet hul (som spidsen af en blyant) med en diameter på ca. $0,75 \mathrm{~cm}$. Selvom flere forskellige tolkningsmuligheder kan tænkes, er det dog mest rimeligt at antage, at 


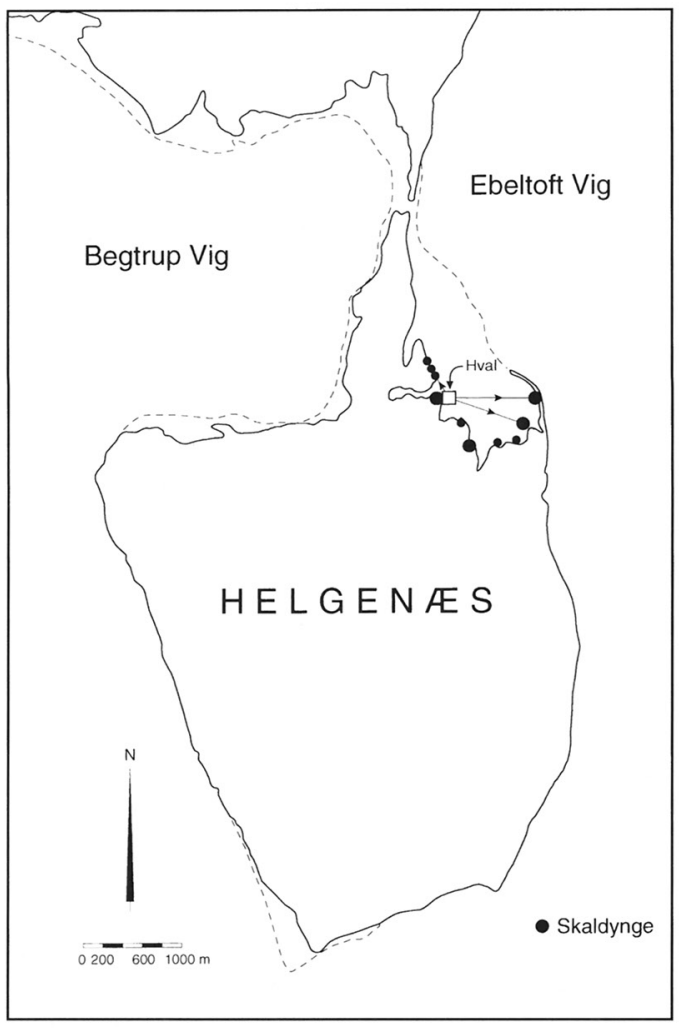

Fig. 30. Kort over Helgenæs med angivelse af Ertebøllebopladser omkring Vængesø. Ved bugtens vestkyst er fremdraget skeletdele af rørhval (markeret med firkant), og på tre nærliggende bopladser er der fundet splintrede hvalknogler (markeret med pile). Tegning: S. Kaae.

Map of Helgenæs showing the Ertebølle settlements around Vængesø. Near the west coast of the bay bones of finback (square) have been found and at three settlements nearby splintered whale bones (arrows).

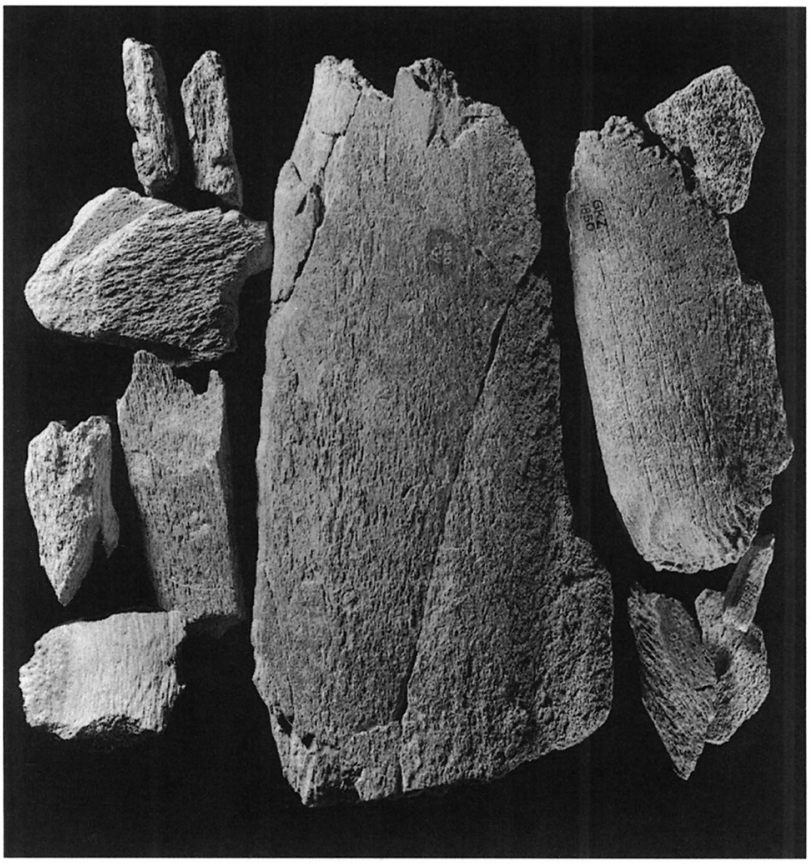

Fig. 31. Splintrede knogler af storhval fra Ertebølleboplads i Vænge Sø. På stykket til højre ses tydelige spor af øksehug.

Foto P. Dehlholm. 1:2.

Splintered bones of a large whale from an Ertebølle settlement in Vænge Sø. On the piece to the right there are distinct axe-marks. 


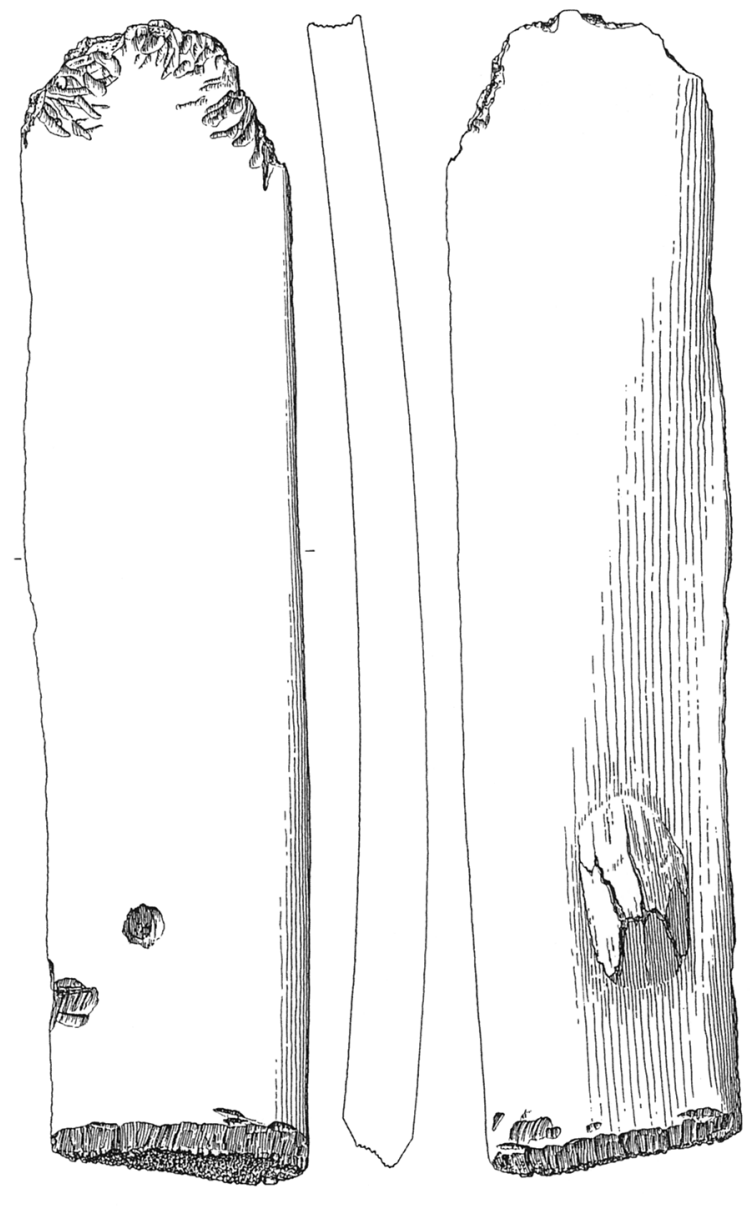

Fig. 32. Ribben af større hval fra undersøisk Ertebølleboplads i Gamborg Fjord. I knoglens ene ende er der gnavemærker efter hundetænder (øverst på tegningen), mens den nedre ende er meget omhyggeligt overhugget med en (skive?-) økse. På ribbenets inderside ses et rundt hul efter et fangstvåben (harpun eller rund benspids), der er trængt ind i, men ikke igennem knoglen.

Tegning: Orla Svendsen. 1:2.

Rib of a large whale from a submerged settlement in Gamborg Fjord. At the upper end there are marks produced by dog teeth, while the lower end has been very carefully chopped away with a flake(?) axe. On the inner side of the rib is a round hole made by a hunting weapon (harpoon or round bone point) which has entered but not completely penetrated the bone.

der er tale om et "skudsår". I så fald fortæller formen, størrelsen og retningen af hullet i knoglen dels, at våbnet må have været en harpun eller benspids, og dels at våbnet forst har ramt dyret i den modsatte side og derefter er trængt skråt igennem dyrets krop, før det til slut et gået ca. 1 $\mathrm{cm}$ ind $\mathrm{i}$ dette ribbens inderside - heri ligger formodentlig også forklaringen på, at våbenet ikke er trængt helt igennem knoglen, men er standset inde $\mathrm{i}$ knoglen.

Tidligere har der været en tilbøjelighed til at antage, at alle knoglefund af (stor-) hval på Ertebøllebopladserne udelukkende afspejlede rester af "naturligt" strandede hvaler (Møhl 1971a, s. 319), men dette synspunkt bør nok modificeres i dag. De mange østjyske fundsteder med knogler af større hvaler kan næppe alle udelukkende repræsentere "strandede" dyr, således som der tidligere er blevet argumenteret for, men kan efter min opfattelse lige så vel være spor efter jagt på disse dyr. 
Muligvis har man jaget disse hvaler ude på åbent hav - en aktivitet, der må have krævet indsats af mange personer i bådhold, og derfor må have været "ledet" eller organiseret af en enkelt eller nogle få jægere. En anden mulighed er, at man bevidst har udnyttet de danske farvandes mange lavvandede områder til systematisk at have skræmt disse store dyr ind på grundt vand, hvor de så efterfølgende er strandede og siden dræbt med harpun og lanse; den sidstnævnte - meget effektive jagtform - som er velkendt fra beskrivelser af hvaljagt $i$ arktiske egne af Nordamerika (Frisen og Arnold 1995), vil næppe kunne påvises ad arkæologisk vej, men må absolut tages med i betragtning ved en samlet vurdering af Ertebøllekulturens jagtformer. At mange af vore skeletfund af hvaler fra Atlantisk tid ikke behøver at være "naturlige" strandinger, men kan have deres forklaring i en sådan jagtform, må ikke glemmes.

Tages de forskellige nedbrydningsprocesser af dyreknoglerne også i betragtning, må de mange fundsteder for hvalknogler afspejle en almindelig og udbredt havjagt på disse dyr, og hvalarterne må have udgjort en ikke uvæsentlig del af jagtbyttet på disse kystbopladser.

De overvejelser vedrørende evt. sæsonprægede "specialbopladser", der blev fremført i forbindelse med omtalen af sæljagten, må også gøre sig gældende med hensyn til forekomsten af større hvalarter på Ertebøllebopladserne, det vil sige, at jagten på disse dyr udmærket kan tænkes i overvejende grad at have fundet sted langt fra bopladserne, hvorfor antallet af knogler på disse steder kun i mindre grad afspejler disse byttedyrs reelle hyppighed (og betydning).

Endelig skal der også gøres opmærksom på, at der på Ertebøllebopladserne er en lille gruppe våben af kraftige, lanseformede spidser ("lænsere"), hvis størrelse og form tyder på, at de meget vel kan tænkes at have været specielt udformet til hvaljagt (S.H. Andersen 1995, s. 60-61 og fig. 23) - hertil kommer de store harpuner af type D, der som før nævnt adskiller sig størrelsesmæssigt fra de øvrige typer, og derfor muligvis har været anvendt til hvalfangst.

Fra det nærmeste udland kendes der jævngamle kystbopladser, hvor fangst af hval tilsyneladende har været langt vigtigere end fangst af sæl, f.eks. bopladsen Frebergsvik i Oslofjorden, hvor hval repræsenterer en så stor del af hele knoglematerialet og de topografiske forhold er af en sådan art, at disse forhold tilsammen peger på en systematisk hvalfangst (Mikkelsen 1975); denne boplads tilhører "Nøstvetkultur", ca. 6500-4200 f.Kr.. Hvalens betydning som byttedyr dokumenteres endvidere af det faktum, at disse dyr jævnligt er afbilledet sammen med andre typer jagtvildt på de norske klipperistninger. Selvom dateringen af disse ristninger langtfra er særlig vel underbygget, henfører norske arkæologer dog en del af disse til ældre stenalder (f.eks. Marstrander 1971).

Det er derfor min tese, at de større hvalarter - på samme måde som 
sæler og småhvaler - har haft en større betydning end tidligere antaget $i$ Ertebøllekulturens erhverv - i hvert fald på bopladserne langs Lillebælt og Østjyllands kyster.

\section{Konklusion}

Siden de danske Ertebølleharpuner for første gang blev fremlagt samlet i 1972 er materialet blevet yderligere forøget med et større antal nye fund, hvoraf adskillige er fra sikkert daterede bopladser, hvilket har forbedret dateringsgrundlaget for de forskellige harpuntyper i betragtelig grad (fig. 1-19). Hertil kommer, at Ertebølleharpunernes geografiske udbredelsesområde nu også omfatter Skåne, større dele af Nordtyskland og videre østpå til Odermundingen, d.v.s. at Ertebølleharpunerne i dag dækker hele denne kulturs udbredelsesområde omkring den vestlige Østersø (fig. 23-24). Hertil kommer også flere nye fund fra indlandslokaliteter i både Danmark og Nordtyskland. Alle fire hovedtyper af Ertebølleharpuner har en geografisk afgrænset udbredelse; mest udpræget med type B, der kun kendes fra kulturens østlige udbredelsesområde - først og fremmest Sjælland og Skåne (fig. 22), muligvis fordi denne type har været særlig tilpasset jagt på de store sæsontræk af grønlandssæl, der har passeret de danske sunde ved forårs- og efterårstide. Et andet regionalt træk er, at de skånske harpuner (og en nordtysk) er dekorerede med små, korte indskårne streger i modhagernes forkant (fig. 14).

Blandt de nye fund er der især grund til at bemærke, at denne redskabsform nu også indgår i en klar rituel sammenhæng, da der for første gang er fundet en harpun i en grav fra æeldre Ertebøllekultur (Skateholm II). Dette fund dokumenterer dels den betydning, man tillagde harpunen som fangstvåben i datiden, dels trækker det en meget tydelig parallel til den langt yngre grubekeramiske kultur (mellemneolitisk tid), hvor harpuner jævnligt medgives som gravgods, og hvor den marine pattedyrfangst indiskutabelt har spillet en meget stor rolle i erhvervet. Denne harpun og den tidligere publicerede fra Tudeå ser ud til at udgøre en ældste type, der skal dateres til overgangen mellem yngre Kongemosekultur og ældre Ertebøllekultur - eller ældre Ertebølle, type A-1. Det er endvidere interessant at bemærke, at en stadig større del af den samlede gruppe af harpuner er fremstillet af hvalknogle; muligvis ligger der også heri et rituelt aspekt.

En analyse af den tidsmæssige placering af de enkelte harpuntyper og varianter, viser, at denne redskabsform dukker op i ældre Ertebøllekultur, men i begyndelsen er fătallig. I løbet af Ertebøllekulturens tid forøges harpunernes antal og typevariation betragteligt for at kulminere $\mathrm{i}$ sen Ertebølletid, hvorfra der kendes flest fund. Det betyder, at der sker en klar differentiering og specialisering af redskabsinventaret til fangst af marine pattedyr i sen Ertebøllekultur, hvilket igen må betyde, at havjag- 
ten på dette tidspunkt har faet en anden og større betydning end tidligere. Harpunen har tydeligvis været et vigtigere våben i yngre Ertebøllekultur end tidligere antaget.

Ertebølleharpunerne har været anvendt til jagt på marine pattedyr som sæler, mindre hvaler (marsvin, delfin og spækhugger) og formodentlig også på større hvaler. De hyppigste og vigtigste byttedyr har været gråsælen og marsvinet. Knoglerne af disse dyrearter er ikke dominerende på kystbopladserne, hvilket sikkert er en kombination af at knoglerne har været udsat for mange forskellige nedbrydningsprocesser $\mathrm{i}$ de forløbne årtusinder og det forhold, at jagten på havdyrene oftest enten foregik på åbent hav eller på rev, rønner og små øer langt fra hovedbopladserne. De marine pattedyrs reelle betydning for de datidige Ertebøllesamfund understreges dels af undersøgelser af næringsværdien af de sæler, der er fundet $i$ f.eks. Meilgaard-køkkenmøddingen, dels af at knogler af disse dyr stort set altid er tilstede på bopladserne - selv på de mindste og på steder med dårlige bevaringsforhold. At der også udvikles et specialvåben som harpunen (og i flere hovedtyper og mange varianter) samt fremkomsten af de såkaldte "spæklamper" (også i yngre Ertebølletid) peger ligeledes i samme retning. Hertil kommer, at knogler af marine dyr også findes på indlandsbopladserne, f.eks. Ringkloster. De betragtninger, der kan fremføres til fordel for, at jagt på marine arter som sæl og småhvaler har været af væsentlig større betydning for Ertebøllekulturens erhverv end tidligere antaget, gælder formodentlig også for de større hvalarter. Knoglefund af større hvalarter er især almindelige langs Lillebælt og den østjyske kyst, hvilket giver disse bopladser et regionalt præg forskelligt fra samtidige Ertebøllebopladser i Limfjorden og i Østdanmark. Hertil kommer at en del af disse hvalknogler viser tydelige hugspor efter økse.

Hidtil har man manglet kystbopladser, hvor den marine havjagt har været særlig fremtrædende $i$ erhvervet, men sådanne lokaliteter er nu også ved at dukke op. Et eksempel er en lille lokalitet i Vængesø på Helgenæs, hvor faunaen - imodsætning til det "normale" - præges af et stort indslag af fisk, søfugle, sæler, småhvaler og større hvaler; af de sidstnævnte findes talrige splintrede knogler og en enkelt viser tydelige øksehug (fig. 31). Hertil kommer et større antal forarbejder og affald - af såvel kronhjortetak som hvalknogle - til harpuner (fig. 29). 


\section{Spækhuggertænder som redskaber i Ertebølletid}

Et andet eksempel på Ertebøllebefolkningens udnyttelse af de marine havpattedyr udgøres af en lille, men interessant gruppe af enkeltfundne tænder af spækhugger (Orca gladiator) på en række østjyske Ertebøllebopladser.

Allerede for mange år siden studsede jeg over, at der forekom enkelte eller ganske få, men meget karakteristiske, kegleformede tænder blandt faunalevnene på en række store, central-østjyske Ertebøllebopladser (fig. 33). Disse tænder blev artsbestemt af Ulrik Møhl, der kunne fastslå, at de stammede fra spækhugger (Orca gladiator). Det påfaldende var, at der selv i meget store faunamaterialer - kun optrådte en enkelt eller nogle fă tænder. Hertil kom disse funds snævre geografiske udbredelse, der var meget slående på baggrund af de mange fund af spækhugger $i$ atlantiske aflejringer fra hele landet, et forhold, der tidligere er omtalt (Aaris-Sørensen 1988, s. 187).

Sådanne enkeltfund af tænder kendes fra en Ertebølleboplads i Vængesø på Helgenæs, fra den tidligere omtalte boplads ved Lystrup Enge (S.H. Andersen 1996), Flynderhage i Norsminde Fjord (Gabrielsen 1953) samt Haldrup Strand og Vorsø i Horsens Fjord - alle østjyske fundsteder. Der er tale om relativt store tænder med en længde på ca. 5-12 cm., og samtidig er der øjensynlig udvalgt tænder med en tydelig krumning.

Både tændernes krumme form og størrelse (længde) mindede påfaldende om Ertebøllekulturens korte og krumme trykstokke, og det var da nærliggende at antage, at disse tænder kunne have tjent som en særlig slags trykstok eller "retucheur" (Taute 1965; Hahn 1992).

I nogle år drøftede jeg dette problem både skriftligt og mundtligt med nu afdøde dr. Ulrik Møhl, der accepterede min ide. Teorien kunne senere underbygges, da der på emaljefladen af en tand fra Flynderhagebopladsen kunne ses tydelige "slid"-ridser (fig. 33,2), og en anden tand fra samme boplads var flækket på langs - øjensynlig som følge af et voldsomt slag eller tryk. Også en stor spækhuggertand fra bopladsen Haldrup Strand (18) har en serie afsprængninger af emaljen på tandens spids tydeligt forårsaget af gentagne tryk (fig. 33,1). Da disse ridser og afsprængninger på tænderne teoretisk set kunne være naturlige, var U.Møhl så venlig at sammenligne disse "skader" med spækhuggertænder i Zoologisk Museums store samling, men uden at det lykkedes ham at finde tilsvarende brud og skader m.m. på tænder fra "ikke-arkæologiske" aflejringer.

Efter min opfattelse er der ingen tvivl om, at der er tale om et specielt Ertebølleredskab anvendt $\mathrm{i}$ forbindelse med forarbejdning af flint eller 

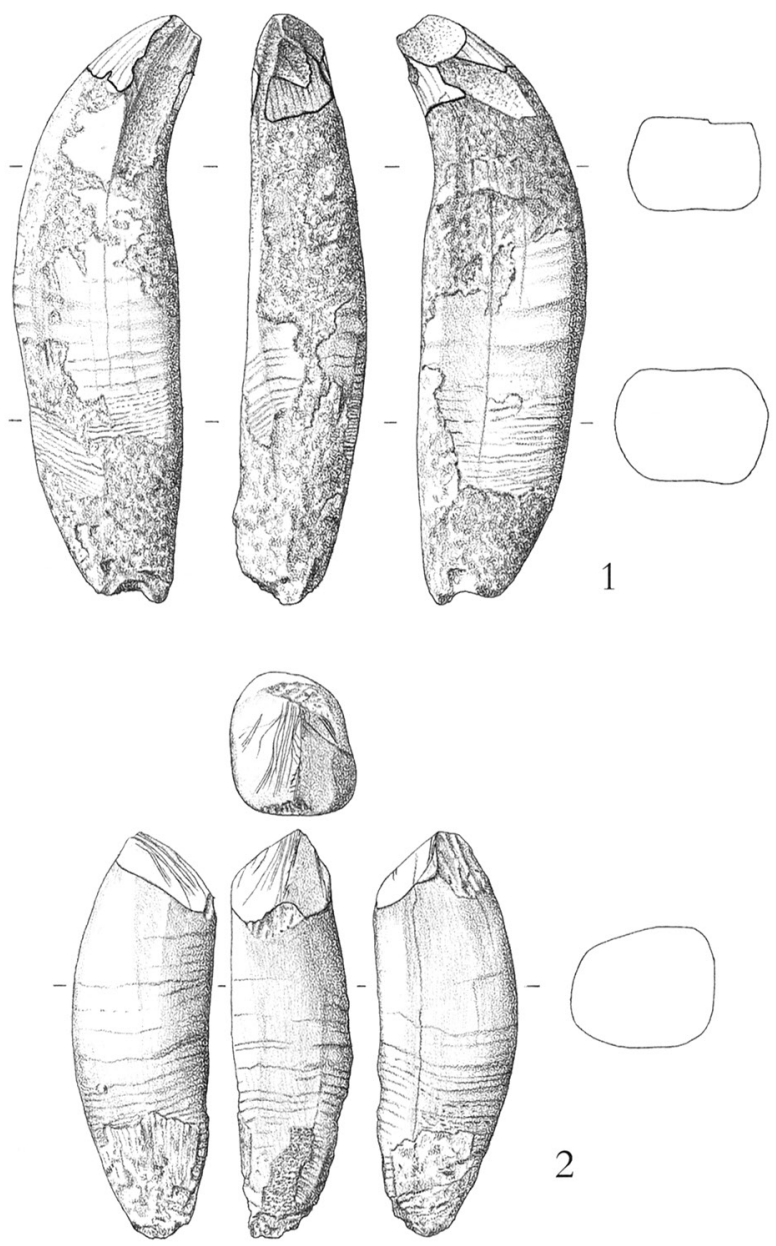

Fig. 33. Tænder af spækhugger med arbejdsspor fremkommet fordi de formodentlig har været brugt som trykstokke. Fra Ertebøllebopladsen Haldrup Strand i Horsens Fjord (1) og Flynderhage-

køkkenmøddingen i Norsminde Fjord (2).På den øverste tand er emaljen på spidsen af tanden sprængt af som følge af pres eller tryk, mens emaljen på den nederste tand er ridset ved brug mod et hårdere materiale (flint eller anden bjergart). Tegning: Louise Hilmar. 1:2.

Fig. 33. Teeth of killer whale with marks of working probably deriving from their use as flaking tools. From the Ertebolle settlement Haldrup Strand in Horsens Fjord (1) and the Flynderhage kitchen midden in Norsminde Fjord (2). On the upper tooth the enamel of the apex has flaked off due to pressure, while the enamel on the lower tooth has been scratched by contact with a harder material (flint or other stone).

anden bjergart, da kun dette materiale kan tænkes at være $\mathrm{i}$ stand til at ridse i tændernes hårde emalje.

De nævnte fund tilhører alle Ertebøllekulturen og dækker hele dennes levetid fra ca 5500-4000 f.Kr.

Redskabsformens meget afgrænsede geografiske forekomst er gådefuld, da der på kystbopladserne teoretisk set må have været adgang til rigelige mængder tænder af spækhugger. Ifølge ældre opgivelser (Winge 1908, s. 227) har en fuldvoksen spækhugger mellem 40 og 52 tænder i gabet, og da skeletdele af spækhugger er almindeligt forekommende i atlantiske havaflejringer i hele landet, burde der have været masser af tænder i fundene.

De kan heller ikke have været $\mathrm{i}$ almindelig brug, da de i så fald ville have været meget hyppigere på bopladserne. Der kunne også være tale om "nødbrug", men dette er i modstrid med den lokale forekomst. Hav- 
de der været tale om en art nødløsning, hvor sådanne tænder lejlighedsvis var anvendt i stedet for slagstokke af kronhjortetak, måtte de have været mere almindelige og udbredt over hele landet.

Forekomsten i det central-østjyske område kunne måske tages som tegn på, at de alle stammer fra et enkelt sted, og derfor måske skal opfattes som en art "lokal eksotika" ?

Konklusionen er, at der er tale om et lokalt, specielt redskab til flintforarbejdning - måske er de distribueret / udvekslet fra eet oprindelsessted og derfra spredt ud over et (stamme-)område ?

Fra europæisk stenalder - især fra yngre palæolitikum - kendes adskillige eksempler på tilsvarende "retucheurer", som er fremstillet af store hjørnetænder - fortrinsvis af bjørn (Hahn 1992, s. 73, Abb. 5, 4, 1). Såvel størrelsen som den krumme form og slidsporenes art og placering på tanden viser et meget stort slægtskab mellem de danske Ertebøllefund og de senpalæolitiske "retucheurer".

\section{Noter}

1) Harpunen, der er opsamlet af cand. phil. Per Borup, Odder, er indgået i Forhistorisk Museums samling og har nr. FHM. 3633 A.

2) Harpunerne fig. 2 og 3 er begge opsamlet af amatørarkæolog Erik Espersen, Århus, der venligst har overladt de to stykker til Forhistorisk Museum, hvor de er katalogiseret under nr. FHM 3998 A og B.

3) Stykket afviger ved sin smalle, spidse form og hullets korte afstand fra basis i nogen grad fra de øvrige harpuner; det kan derfor ikke afvises, at dette stykke måske snarere har fungeret som en nål el.lign..

4) Harpunen er fundet af - og ejes af - amatørarkæologen Jens Chr. Lau, Foldingbro.

5) På lokaliteten er der ved flere lejligheder gennemført systematiske bopladsudgravninger ved forfatteren (upublicerede) . Fundet er arkiveret på Forhistorisk Museum under FHM j.nr. 1850.

6) Harpunen er venligst udlånt af Møns Museum til fotografering og beskrivelse. Den er fundet d. 22/8-1980 fă hundrede meter vest for Klintholm Havn; nær kysten på et område, der normalt er lavvandet, men som den pågældende dag var tørlagt på grund af usædvanlige vand/vejrforhold. Den har Møns Museum nr. 14414.

7) Harpunen har Nationalmuseet (OMA)nr. A 52074.Journal nr. 6739/88. Den er opsamlet på overfladen af mosen ca. $10 \mathrm{~m}$ syd for en flintkoncentration, der sandsynligvis er identisk med Knud Andersens lokalitet: Kildegård komplekset nr. 13. Sb. 216, Undløse s., Merløse h., Holbæk amt.

8) Harpunfragmentet har nr. NM 1, A 47875 med undernummer Ts 467; dette er meddelt af K. Andersen i brev af 16/8-1974.

9) Harpunen har Nationalmuseet (OMA) nr. A. 51096. Journal nr. 3183/80. Harpunen er fundet $\mathrm{i}$ løbet af perioden 1925-1935 enten omkring Højerup Gl.Kirke eller ved Højerup Gadekær, Højerup s. , Stevns h., Præstø amt.Yderligere fundoplysninger findes desværre ikke.

10) Museumsleder Anders Jæger, Nordfyns Museum i Bogense, har venligst givet mig tilladelse til at omtale og afbilde de tre harpuner fra Agernæs bopladsen. Figur 9 og 11 har tidligere været gengivet i: Arkæologiske Udgravninger i Danmark 1987 (se Jæger 1988)

11) Dateringen af Ertebøllebopladsen Agernæs hviler på et typologisk grundlag, der klart henfører lokaliteten til yngre - yngste Ertebøllekultur.

12) Systematisk bopladsudgravning og opsamling ved submarin Ertebølleboplads. Fundet er upubliceret og opbevares på Forhistorisk Museum under FHM j.nr. 3705. 
13) På Tudse Hage bopladsen er der fundet adskillige stænger og sprodser af kronhjortetak med spor af "skure-rende teknik", hvilket viser, at der har været en omfattende fremstilling af harpuner på denne boplads.

14) De to basisstykker har ikke tidligere været publicerede. De har museumsnumrene NM 1, A 41768 og SKK 320. De er fundet i et nu tørlagt sund nord for Selsø Sø. Stykkerne og fundoplysningerne er venligst stillet til min rådighed af mus. insp. Søren A. Sørensen, Museet Færgegården i Jægerspris.

15) Upubliceret bopladsudgravning ved forfatteren. Forhistorisk Museum j.nr. 3820.

16) Upubliceret bopladsudgravning ved forfatteren. Forhistorisk Museum j. nr. 1850 (se note 5).

17) Faunamaterialet er artsbestemt af Dr. P. Rowley-Conwy, Dept. of Archaeology, University of Durham, U.K.

18) Upubliceret undersøgelse af submarin Ertebølleboplads ved Haldrup Strand, Horsens Fjord.

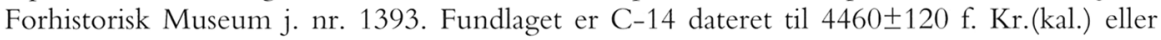
4580-4350 f.Kr. + 1 stdv.) (K-1612).

19) Harpunen blev i den første fremlægning (S. H. Andersen 1972 anf. arb.) anført som "uden funddata", da det påskrevne nummer blev læst som NM 1, 8985, hvilket ikke kunne spores se S. H. Andersen 1972, s. 83, fig. 11 og note 36. Senere er nummeret læst som S. 9 85, der refererer til en særnummerering af fundene fra den upublicerede udgravning af en stenalderboplads i Salpetermosen, der blev udgravet i 1956 ved stud. mag H. Thrane; beretning i NM 1 's arkiv af 6/7-60. Hele fundstoffet er indført under hovednummeret A. 45419. Denne harpun kan derfor nu med sikkerhed henføres til denne indlandsboplads, der har kulturlag fra både Kongemose- og Ertebøllekultur. Museumsinspektør P.Vang Petersen takkes for venlighed og hjælp med de ovennævnte oplysninger.

\section{LITTERATUR}

Alciati, G. et al., 1994: Mondeval de Sora: A high altitude Mesolithic campsite in the Italian Dolomites. Prehistoria Alpina - Museo Tridentino di Scienze Naturali. Vol. 28 (1992), s. 351-366. Trento.

Andersen, Søren H., 1972: Ertebøllekulturens harpuner. Kuml 1971, s. 73-125.

Andersen, Søren H., 1975: En Ertebølleboplads ved Vængesø. Hikuin 2, s. 9-48.

Andersen, Søren H., 1976: Nye harpunfund. Kuml 1975, s. 11-28.

Andersen, Søren H., 1983: Harpunen fra Føns Vig. Fynske Minder 1982, s. 7-16.

Andersen, Søren H., 1985: Tybrind Vig. A Preliminary Report on a Submerged Ertebølle Settlement on the West Coast of Fyn. Journal of Danish Archaeology vol.4, s. 52-69.

Andersen, Søren H., 1992: Marin udnyttelse af Limfjorden i stenalderen. Limfjordsprojektet. Rapport nr. 4: Limfjordsfiskeri i fortid og nutid. Århus, s. 65-96.

Andersen, Søren H., 1995: Coastal adaption and marine exploitation in Late Mesolithic Denmark - with special emphasis on the Limfjord region. I: A.Fischer (red.): Man E Sea in the Mesolithics, s. 41-66. Oxbow Monograph 53. Oxford.

Andersen, Søren H., 1996: Ertebøllebåde fra Lystrup. Kuml 1993 - 94, s. 7-38.

Andersen, Søren H., T.S. Constandse - Westermann, R. R. Newell, R. Gillespie, J. A. J. Gowlett and R.E.M. Hedges, 1986: New Radiocarbon Dates for two Mesolithic Burials in Denmark. I: J.A.J.Gowlett and R.E.M.Hedges (eds. ): Archaeological Results from Accelerator Dating. Oxford University Committee for Archaeology, Monograph 11, s. 39-43. Oxford .

Bailey, G.N., 1978: Shell middens as indicators of postglacial economies: a territorial perspective. I: P.Mellars (ed.) : The Early Postglacial Settlement of Northern Europe. An Ecological Perspective, s. 37-63. London.

Bandi, H. -G., 1963: Birsmatten Basisgrotte. Acta Bernensis I. Bern.

Becker, C. J., 1939: En Stenalderboplads paa Ordrup Næs i Nordvestsjælland. Bidrag til Spørgsmaalet om Ertebøllekulturens Varighed. Aarbøger for nordisk Oldkyndighed og Historie 1939, s. 199-280. København.

Berglund, J., 1979: Mortensdag til kyndelmisse. Skalk, Nr. 6, s. 18-24.

Broholm, H.C., 1928: Langøfundet. En Boplads fra den ældre Stenalder paa Fyn. Aarbøger for nordisk Oldkyndighed og Historie 1928, s. 129-190. København. 
Clark, J.G.D., 1976: A Baltic Cave Sequence: A Further Study in Bioarchaeology. Festschrift für Richard Pittioni zum siebzigsten Geburtstag, s. 113-123. Wien.

Clark, J.G.D., 1989: Economic prehistory: papers on archaeology. Kapitel 4 : Seal-Hunting in the Stone Age of North-Western Europe: A Study in Economic Prehistory, s. 47-86. Cambridge.

Coles, J., M., 1971: The early settlement of Scotland; excavations at Morton, Fife. P. P. S. vol. 37, s. 284-366

Czarnecki, M., 1976: Chronologia harpuna z Podjuch. Materialy Zachodniopomorskie. t. XVIII, s. 713.

Didriksen, H., 1953: Bidrag til Syd-Hads-Herreds forhistorie. 25 aars arbejde i "marken". Aarboger udgivne af Historisk Samfund for Aarhus Stift XLVI, s. 17-40.

Frisen, T., M., and C. Arnold, 1995: Zooarchaeology of a Focal Ressource: Dietary Importance of Beluga Whales to the Precontact Mackenzie Inuit. Arctic. Vol. 48. No.1, s. 22-30.

Gramsch, B., 1973: Das Mesolithikum im Flachland zwischen Elbe und Oder. Veröffentlichungen des Museums für Ur- und Frühgeschichte Potsdam. Bd.7. Berlin.

Hahn, J., 1992: Zeichen von Stein- und Knochenartefakten. Archaeologica Venatoria, Bd.13. Tübingen.

Hartz, S., 1997: Ertebøllekultur im Travetal. Stormarner Hefte. Denkmalpflege im Kreis Stormarn III. 20, s. 171-186.

Hernek, R. og B. Nordqvist, 1995: Världens äldsta tuggummi? Riksantikvarieämbetet. Kungsbacka.

Hiraguchi, T., 1992: Cathing Dolphins at the Mawaki Site Central Japan, and Its Contribution to Jomon Society. I: C.M. Aikens og S. N. Rhee (red.): Pacific Northeast Asia in Prehistory. Hunter -Fisher-Gatherers, Farmers, and Sociopolitical Elites, s. 35-44. Washington State University Press. Washington.

Hiraguchi, T., 1993: The Variety of Ancient Whaling. Kanazawa Medical Iniversity, IBI Reports No 4, s. 49-56

Hiraguchi, T., 1995: The Origins of Whaling in Japan and Europe. Kanazawa Medical University, IBI Reports No.5, s. 65-74.

Janzon, G., 1974: Gotlands mellanneolitiske gravar. Acta Archaeologica Stockholmiensis 6. Stockholm.

Jæger A., 1988: Agernæs. Arkaologiske udgravninger i Danmark 1987, s. 122-123. Det Arkæologiske Nævn, København 1988.

Kapel, H., 1969: En boplads fra tidlig-atlantisk tid ved Villingebæk. Fra Nationalmuseets Arbejdsmark. 1969, s. 85-94.

Larsson, L., 1982: Segebro. En tidigatlantisk boplats vid Sege Ås mynning. Malmöfynd 4. Malmö Museum. Malmö.

Larsson, L., 1984: The Skateholm Project. A Late Mesolithic Settlement and Cemetery Complex at a Southern Swedish Bay. Meddelanden från Lunds universitets historiska museum 1983-1984, s. 538. Lund. s. 10, fig. 4,11.

Larsson, L., 1987: Uppspolad stenåldersharpun. Skepparpsåns museiförening. Meddelanden \& Bygdehistorik. Årg. 1, Nr. 4, s. 62-64.

Larsson, L., 1988a : Fortsættelse af ovenfor anførte artikel. Skepparpsåns museiförening.Meddelanden E Bygdehistorik. Årg. 2, Nr.1, s. 65-71.

Larsson, L., 1988b : Et fångstsamhälle för 7000 år sedan.

Larsson, M., 1986: Bredasten. An Early Ertebølle Site with a Dwelling Structure in South Scandinavia. Meddelanden frän Lunds universitets historiska museum 1985-86, s. 25-51.

Liversage, D., 1973: Sejerøs forhistorie. Fra Holbck Amt 1973, 66 årg., s. 85-122. Historisk Samfund for Holbæk Amt. Holbæk 1973.

Lotz, P., 1996: Dyk ned i fortiden. SDA Nyt, februar 1996, s. 4-17. (Sammenslutningen af danske amatørarkæologer)

Mackie, E. W., 1972: Radiocarbon dates for two Mesolithic shell heaps and a Neolithic axe factory in Scotland. P. P. S. vol. 38, s. 412-416.

Madsen, A. P., Müller, S., Neergaard, C., Petersen, C.G. J., Rostrup, E., Steenstrup, K. J. V. \&Winge, H., 1900: Affaldsdynger fra Stenalderen $i$ Danmark. Undersøgte for Nationalmuseet. København. 
Malmros, C., 1995: Hjortholm-køkkenmøddingen. Sten- og bronzealder omkring Stavns Fjord. I: H.Hansen og B.Aaby (red.): Stavns Fjord - et natur- og kulturhistorisk forskningsområde påSamsø, s. 35-58. København.

Marseen, O., 1953: Fangstfolk på Selbjerg. Kuml, s. 102-120.

Marstrander, S., 1971: Et magisk fangstlokkemiddel. Kuml 1970, s. 211-222.

Mathiassen, Th., 1946: En Boplads fra ældre Stenalder ved Vedbæk Boldbaner. Sollerødbogen 1946, s. $19-35$.

Mathiassen, Th., 1948: Danske Oldsager I. Ældre stenalder. København.

Mellars, P., 1987: Excavations on Oronsay. Edinburgh.

Mestorf, J. og C.A.Weber, 1904: Wohnstätten der älteren neolithischen Periode in der KielerFöhrde. 43. Bericht des Schleswig-Holsteinischen Museums vaterländischer Altertümer bei der Universität Kiel, s. 9-30.

Mikkelsen, E., 1975: Frebergsvik. Et mesolitisk boplassområde ved Oslofjorden. Universitetets Oldsaksamlings skrifter - ny rekke. Nr. 1. Oslo.

Møhl, U., 1971a: Fangstdyrene ved de danske strande. Den zoologiske baggrund for harpunerne. Kuml 1970, s. 297-330. Århus.

Møhl, U., 1971b: Oversigt over dyreknoglerne fra Ølby Lyng. Aarbøger for nordisk Oldkyndighed og Historie 1971, s. 43-77.

Paludan-Müller, C., 1978: High Atlantic Food Gathering in Northwestern Zealand. Ecological Conditions and Spatial Representation. I: K. Kristiansen \& C. Paludan-Müller (red.): New Directions in Scandinavian Archaeology. Studies in Scandinavian Prehistory and Early History. Vol. I, s. 120-157. Nationalmuseet. København.

Petersen, E. B. og P.V. Petersen, 1978: Bergmansdal - for 7000 år siden. Helsingør Bymuseums $\AA$ Arbog 1978, s. 5-28.

Petersen, P.V., 1984: Chronological and Regional Variation in the Late Mesolithic of Eastern Denmark. Journal of Danish Archaeology vol 3., s. 7-18.

Petersen, P. V., 1996: Fiskeben. Skalk 1996, Nr. 1, s. 16-17.

Petersen, A., 1969: Marsvin og marsvinsjogere. Middelfart.

Petzsch, W., 1928: Die Steinzeit Rügens. Schriften der Ges. d. Freunde und Förderer der Univ. Greifwalds. Mitteilungen der Gesellschaft der Freunde und Förderer der Universität Greifswald III, Taf. II, nr. 7.

Schwabedissen, H., 1972: Rosenhof (Ostholstein), ein Ellerbek-Wohnplatz am einstigen Ostseeufer. Archäologisches Korrespondenzblatt 2, s. 1-8.

Schwabedissen, H., 1994: Die Ellerbek - Kultur in Schleswig - Holstein und das Vordringen des Neolithikums über die Elbe nach Norden. I: Hoika, J. og J. Meurers - Balke (red.): Beiträge zur frühneolithischen Trichterbecherkultur im westlichen Ostseegebiet. 1.Internationales Trichterbechersymposium in Schleswig vom 4. bis 7. März 1985, s. 361-401. Untersuchungen und Materialien zur Steinzeit in Schleswig-Holstein 1. Neumünster.

Skaarup, J., 1973: Hesselø - Sølager. Jagdstationen der südskandinavischen Trichterbecherkultur. Arkæologiske Studier I. København.

Skaarup, J., 1980: Undersøisk stenalder. Skalk 1980, Nr. 1, s. 3-8.

Skaarup, J. 1985: Yngre stenalder på øerne syd for Fyn. Langelands Museum. Rudkøbing.

Stenberger, M., 1939: Das Västerbjersfeld. Ein Grabfeld der Ganggräberzeit auf Gotland. Acta Archaeologica X, s. 60-105.

Sørensen, S. A., 1996: Kongemosekulturen i Sydskandinavien. Egnsmuseet Færgegården.

Tauber, H., 1981: Kostvaner i forhistorisk tid - belyst ved C-13 målinger. I: Nørrevang (red.): Det skabende menneske Bd. 1. Kulturhistoriske skitser tilegnet P.V.Glob 20 februar 1981. Nationalmuseet, s. 112-126. København.

Taute, W., 1965: Retoucheure aus Knochen, Zahnbein und Stein vom Mittelpaläolithikum bis zum Neolithikum. Fundberichte aus Schwaben. Neue Folge 17, s. 76-102.

Tringham, R., 1971: Hunters, Fishers and Farmers of Eastern Europe 6000-3000 B.C. London.

Westerby, E. 1927: Stenalderbopladser ved Klampenborg. København.

Winge, H., 1908: Pattedyr. Danmarks Fauna bind 5. København.

Aaris-Sørensen, K., 1988: Danmarks forhistoriske dyreverden. Fra istid til vikingetid. København. 


\section{Ertebølle harpoons and killer whale teeth Aspects of marine hunting in the Ertebølle period}

Since the Danish Ertebølle harpoons were presented together nearly twenty-five years ago (Andersen 1972, 1976 and 1983), figs. 1-8, 12 and 19-20, several new finds have been made, a number of which are from excavations of well-dated settlement finds, figs. 9-11 and 13-18. Moreover, harpoons have now been found in Scania, northern Germany and in northern Poland, so they now cover the entire Ertebølle cultural province around the western Baltic, figs. 22-23. Most of the finds are, as previously, from coastal settlements and the sea, but several new finds also come from inland tracts. Further harpoons derive from areas from which several finds were already known, for example from the Little Belt area and Horsens Fjord, figs. 22-23.

It is also interesting that an increasingly large number of harpoons made of whale bone have been found, and waste from whale-bone harpoon production is also known from several new settlement finds, figs. 25 and 28 .

Among the new finds there is also a patterned harpoon of type $\mathrm{C}$ from the settlement excavation at Lystrup Enge (early Ertebølle culture), fig. 16. Corresponding ornamented harpoons were previously known only from Horsens Fjord; a harpoon of this kind has subsequently been found at Podjuch near the mouth of the Oder, fig. 19. The original division into 4 main types, types $\mathrm{A}, \mathrm{B}, \mathrm{C}$ and $\mathrm{D}$, has been further strengthened with the latest finds, figs. 22-23. In addition, it is now possible to define a small group comprising an even older type, A-1, represented by the harpoons from Tudeå and Skateholm, fig. 15; this group must be dated to the latest Kongemose culture or the transition between the Kongemose and Ertebølle cultures, c. 5500/5400 BC.
Among the new finds it is also remarkable that a harpoon has now for the first time been found in a grave from Skateholm II in Scania, fig. 15. This find really documents the importance of the harpoon at that time as a hunting weapon, and draws clear parallels up to the much later (middle Neolithic) Pitted Ware culture, when harpoons were frequently placed in the graves and when the hunting of marine mammals - especially seals - indisputably played a major role.

All four types of Ertebølle harpoons have a geographically limited distribution, figs. 22-23. Type B is most remarkable in that it is known only from the eastern part of the Ertebølle area, fig. 22. This type was possibly specially adapted to the hunting of the seasonally migrating harp seals, which passed through Danish waters in spring and autumn. Another regional feature is that the Scanian harpoons (and a single north German one) are decorated with small incised lines across the front edge of each barb, fig. 14.

The Ertebølle harpoons of types A, B and $\mathrm{D}$ are always of red-deer antler or whale bone, while type $\mathrm{C}$ is made of roe deer antler. The consistent and clear division into four different harpoon types shows that the harpoons must have been designed for different game animals and situations. It is most likely that they were used to hunt marine mammals, first and foremost seals, and perhaps porpoises. Only harpoons of type D seem to have been so much larger that they could have been used for another purpose, perhaps against the large whales.

The Ertebølle harpoons are among other things characterized by their raw material (mainly red-deer antler), by having a relatively long tongued base, large sturdy barbs and a symmetrically placed 
line-hole. The length is between 12 and $32 \mathrm{~cm}$, the width between 1.8 and 4.7 $\mathrm{cm}$, and the line-hole is on average $5 \mathrm{~cm}$ from the end of the base.

If one looks at the chronological occurrence of the harpoons, it is apparent that harpoons are not known from the early Kongemose culture (6800)-6100 BC); from the later Kongemose culture (610)$5400 \mathrm{BC}$ ) only very few harpoon finds (of type A-1) are known. From the early Ertebølle culture (5400-460)) there are slightly more finds of type $\mathrm{B}$ and type $\mathrm{C}$ harpoons. By far the majority of the harpoons of all four main types should be dated to the middle and - especially later Ertebølle culture (4600-3900 BC); this is apparent from several well-dated settlement finds and typological (relative) datings. It is a fact that the harpoons increase markedly in number and morphological differentiation and variation in the late Ertebølle culture. It is evident that in the later Ertebølle culture there is a differentiation of types and specialization for marine hunting. This must mean that marine hunting acquired greater importance in relation to earlier phases in the late Mesolithic.

The overall find picture as it appears today shows that the harpoon has been a much more common and important hunting weapon in the Ertebølle culture than previously assumed. This is clear not only from the new finds but also from the many settlements in which waste from harpoon production has been found, see for example fig. 25. The commonest game has been grey seal, harp seal and porpoise. Many finds of the characteristic broken-off base parts of harpoons, figs. 14.2 and 24 , show that the harpoon point must have been set into an oblong cavity in the end of the shaft.

Seal bones are found at almost all Ertebølle coastal settlement sites - rarely in particularly large numbers but quite constantly, even at small settlements and at sites with poor conditions of preservation for organic remains. Seals were very important, yielding good fur, meat and masses of blubber. The relative shortage of bones at the settlements is probably due to a combination of circumstances: hunting often took place on small islands, forelands and stony shoals - places remote from the main settlements - and a whole series of destructive factors was probably operative over the centuries. In order to estimate the real importance of seals for the Ertebølle population, it is more important to ascertain the constant presence of bones of these game animals rather than the actual and relatively small number of bones. Also calculations of the nutritive value shows that they must have been much more important than formerly believed. Finally, the importance of these mammals is apparent from the fact that a specialized hunting weapon was made in several versions (harpoons) and that there was a simultaneous presence of blubber lamps in the Ertebølle culture.

The conclusion is that the hunting of these marine mammals must have been of much greater importance than formerly believed.

Similar considerations and conclusions must presumably also apply to other species of marine mammals, first and foremost porpoises, the seasonal migrations of which have been exploited in some parts of Denmark right up to the present day, and have undoubtedly also been exploited in Ertebølle context. From the coastal settlements there are many finds of this cetacean, and the animals were probably subjected to driving - probably with net as known from, for example, Japan's early Jomon phase - and by closing off parts of the sea, for example in the Little Belt.

One of the problems in judging the importance of hunting marine mammals in the Ertebølle culture has been an almost complete lack of coastal settlements where these species have been predominant in the fauna, "specialized" coastal hunting sites. Such settlements are, however, now turning up, for example at Vængesø, southern Mols, fig. 26. In this area there are both partially excavated settlements with a considerable comple- 
ment of marine species and several settlements where many splintered bones of large whales have been found. Among other things, one bone has distinct axemarks, fig. 27.

Whether the harpoons have also been used in the hunting of large cetaceans is a more open question, but it is in my opinion likely. Bones of such whales occur so commonly in east Jutland Ertebølle settlements that they help to give these localities a regional character in relation to east Danish and north Jutland find-places from the same period.

Previously, it was thought that these bones all derive from "naturally" stranded whales. There are so many, however, that it can hardly be the only explanation for the presence of these animals at the Ertebølle settlements: it is far more likely that these bones represent bagged animals. It is also possible that the whales were systematically driven into the relatively large areas of shallow water found in Denmark, where they could more easily be killed, in which case the strandings should not be considered "natural", but "cultural". That whaling, however, was also carried out with weapons is apparent from the find of a rib of a relatively large whale on which a distinct round hole is seen, stemming from a weapon which, after penetrating one side of the animal, passed through it to stop in a rib on the opposite side, fig. 28. My conclusion is that hunting large whales must have been of considerable importance in the Ertebølle culture - and considerably more so than previously thought - at least in east Jutland. There is reason to evaluate or revaluate the importance of hunting marine mammals such as seal, porpoise and whale in the Ertebølle culture. The hunting of these animals has apparently been much more common and important than previously believed especially in the late Ertebølle culture.

Finally a small group of killer-whale teeth found singly at a small, locally delimited group of east Jutland Ertebølle settlements, fig. 29, is mentioned. These teeth display a number of characteristic scratches from wear and apical flaking of enamel, owing to pressure. The size, characteristic curved shape and damage has led to these teeth being interpreted as flaking tools or "retouchers". This is a new kind of implement in the Danish Ertebølle culture.

Søren H. Andersen

Nationalmuseets marinarkæologiske Forskningscenter, Roskilde

Oversattelse: Peter Crabb 
